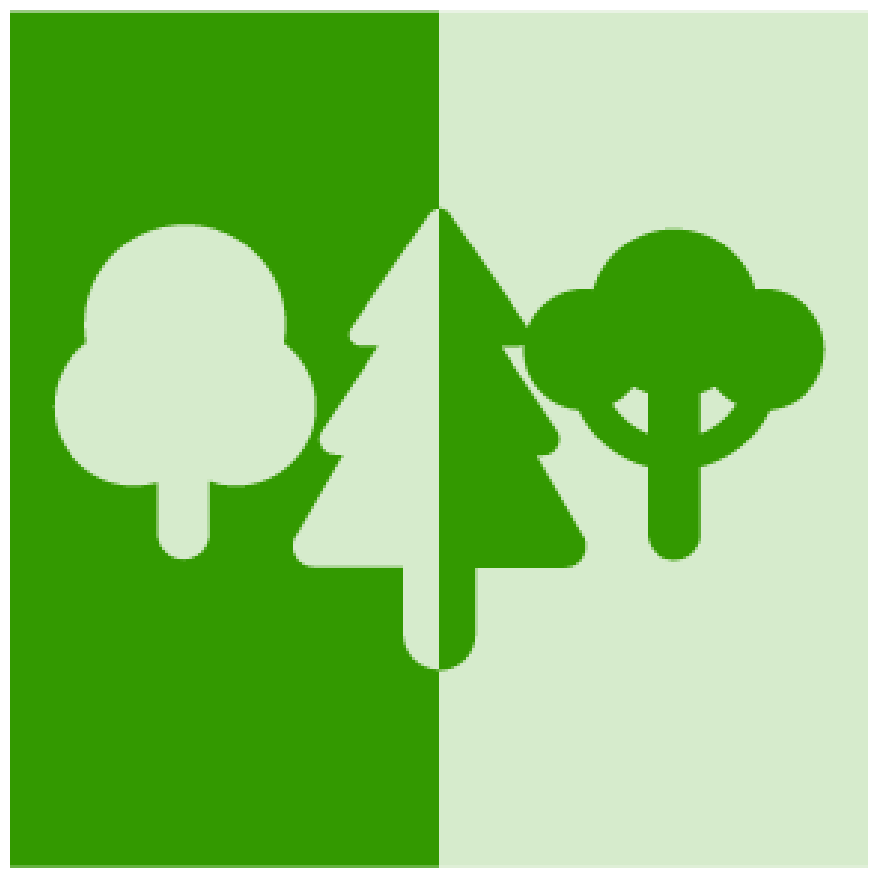

\title{
Bio Sequestration at the University of Michigan
}

\section{A Report Developed for and Supported by the U-M President's Commission on Carbon Neutrality Revised June 21, 2020}

\section{Creators}

Nicole Blankertz

Hannah G. Mosiniak

Lara K. O'Brien

Caleb Short

Chenyang Su

Cyrus Van Haitsma

Heather A. Dawson, Faculty Co-Lead

Rebecca K. Tonietto, Faculty Co-Lead 
Copyright (C) 2021 by the Regents of the University of Michigan

Some rights reserved

\section{(c) (i) $(9)$}

This work is licensed under the Creative Commons Attribution-NonCommercial-NoDerivatives 4.0 International License. To view a copy of this license, visit http://creativecommons.org/licenses/by-nc-nd/4.0/ or send a letter to Creative Commons, PO Box 1866, Mountain View, California, 94042, USA.

Published in the United States of America by Michigan Publishing

DOI: http://doi.org/10.3998/mpub.12091903

ISBN 978-1-60785-684-9 (open access)

This publication is a result of work sponsored by the University of Michigan (U-M) President's Commission on Carbon Neutrality (PCCN) to inform the PCCN's final recommendations to U-M President Mark Schlissel. This publication does not reflect Commission-level recommendations, and should not be interpreted as being recommendations of the PCCN nor carrying its endorsement. 


\section{CONTENTS}

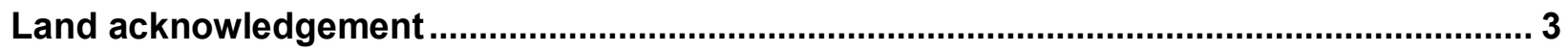

EXECUTIVE SUMMARY .............................................................................................. 4

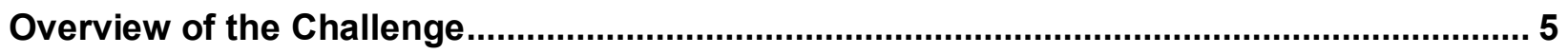

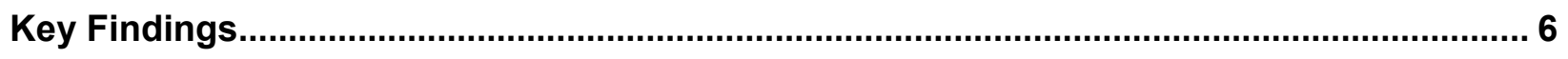

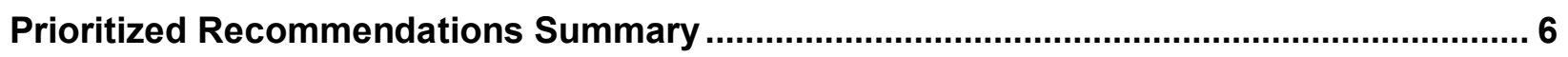

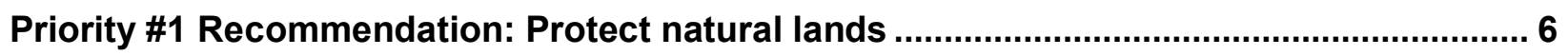

Priority \#2 Recommendation: Restore and enhance natural lands...................................... 8

Priority \#3 Recommendation: Cultivate physical and cultural campus landscapes with ecologically and environmentally friendly practices prioritizing justice, inclusivity, and transparency.

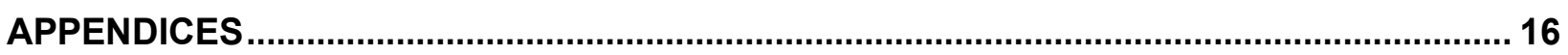

Appendix A - Land acknowledgement resources ............................................................ 16

Appendix B - Recommendations summary matrix ........................................................... 19

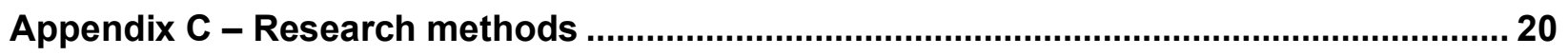

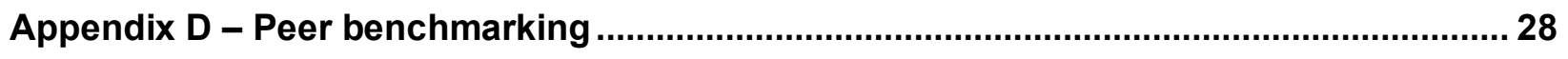

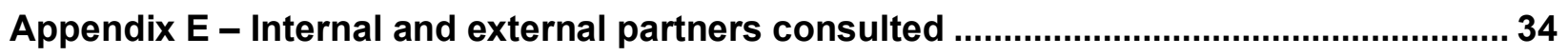

Appendix F - Ecosystem services provided by natural lands ........................................... 37

Appendix G - Details on additional wetland properties ................................................44

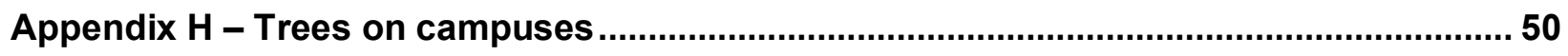

Appendix I - Green infrastructure ............................................................................ 51

Appendix $\mathbf{J}-$ Wetland preservation, tree protection, and turfgrass conversion considerations for the Ann Arbor campus .................................................................... 56

Appendix K - Biosequestration rates and their timelines of land cover types and proposed projects with costs and descriptions of tradeoffs for land conversion ............. 58

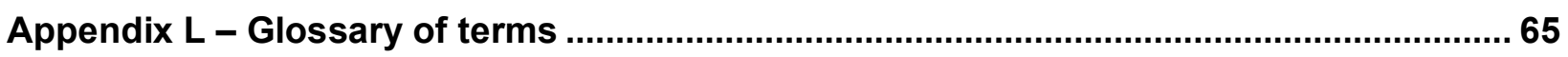

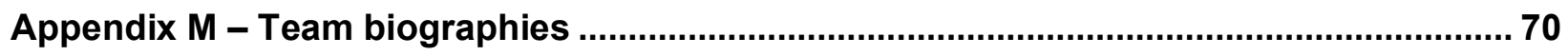

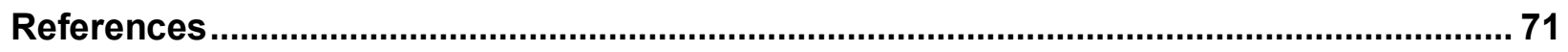


We would like to acknowledge that we are not experts in this area but believe it is important to highlight the absence of a formal, official, and visible land acknowledgement for the University of Michigan.

\section{Land acknowledgement}

We, the Biosequestration Internal Analysis Team (IAT), have determined existing land use and land cover of property currently owned by the University of Michigan (U-M) for the purposes of making biosequestration-optimized recommendations to the President's Commission on Carbon Neutrality (PCCN). To our knowledge, this is the first time all U-M landholdings have been assessed as stated. Thus, we first must acknowledge that U-M is located on the traditional territory of the Anishinaabe and Shoshone (Shoshoni) people. As a precursor to our biosequestration-related recommendations regarding land use, we call attention to the need for an official, visible, and formal land acknowledgement by U-M, which will not improve biosequestration potential of the land but is essential. We have provided resources in Appendix A of examples of land acknowledgements from other institutions as well as locations, events, and ceremonies where land acknowledgements are included and observed. We urge that U-M not let the conversation end with a land acknowledgement but rather see this as the beginning of a cultural shift to more visibly acknowledge the historic significance of U-M landholdings and the ongoing contributions of Native Americans to Michigan and our global society.

\section{Recommendations}

- A university-wide land acknowledgement statement should be created, as currently only select colleges within U-M have such statements (e.g., College of LSA).

- This university-wide land acknowledgement should be read at the beginning of formal events and prominently published online and in printed materials.

- A succinct land acknowledgement should be used in the signature lines of emails or communications from U-M administration.

- Each U-M entity holding land (e.g., U-M Biological Station, U-M School for Environment and Sustainability, Matthaei Botanical Gardens, and Nichols Arboretum) should acknowledge the specific tribal history of the land they now occupy through signage on their property and in online and printed material.

- A unit should exist on campus at which U-M entities can research to better understand the history of the land they occupy. The Bentley Historical Library is the recommended unit.

- Signage and materials involving projects on U-M lands to improve biosequestration (recommended later in this document) and sustainability should acknowledge the specific tribal history of the associated land. 


\section{EXECUTIVE SUMMARY}

This report was compiled during the academic year of 2019-2020 for the University of Michigan President's Commission on Carbon Neutrality. In the following document, the Biosequestration Internal Analysis Team evaluates and recommends approaches for optimizing biosequestration on land owned or managed by the University of Michigan (U-M). The team defined its scope as having three overarching goals: 1) assessment of current U-M landholdings, 2) categorization of land use on U-M properties by estimation of carbon storage and biosequestration rates, and 3) evaluation of land-use changes, where possible, that would maximize biosequestration potential. Through our data gathering process, we reviewed approaches of comparable institutions and discussed opportunities and potential barriers of different methods to increase biosequestration with internal and external stakeholders and experts.

Before we describe biosequestration-related recommendations, we want to first acknowledge that U-M is located on the traditional territory of the Anishinaabe and Shoshoni people. We request formalized language for a university-wide land acknowledgement to be included in signage on U-M properties and in U-M written materials as well as read at U-M events and ceremonies (see Appendix A).

Our analysis resulted in three prioritized recommendations, each of which contains a number of sub-recommendations (see Appendix B):

1. Protect and expand U-M owned natural lands and include their ecosystem service contribution in land-use decision-making processes.

a. Protect U-M owned natural lands in perpetuity.

b. Include valuation of ecosystem services provided by natural lands in U-M expansion planning.

c. Purchase and protect undeveloped sites contiguous with current natural landholdings with prioritization of wetland ecosystems.

2. Enhance biosequestration potential on U-M owned natural lands through restoration and enhancement.

a. Convert agricultural land to wetland.

b. Provide resources for restoration and enhancement efforts on natural lands.

c. Provide resources for long-term management of natural and restored lands.

3. Cultivate physical and cultural campus landscapes with ecologically and environmentally friendly practices prioritizing justice, inclusivity, and transparency.

a. Plant trees to increase campus canopy cover to $60 \%$.

b. Replace turfgrass with environmentally and ecologically friendly alternatives.

c. Create green infrastructure, including rain gardens, native gardens, bioswales, and green roofs. 


\section{FINAL REPORT}

\section{Overview of the Challenge}

Biosequestration is the process by which plants and other microorganisms capture carbon dioxide from the atmosphere. First discovered in the late 1700 s as the ability of plants to collect carbon from the air (via photosynthesis) and store carbon structurally via growth (e.g., in wood, photosynthetic tissues, roots, etc.), biosequestration currently plays a large role in mitigating carbon emissions on local and global scales.

This natural form of carbon capture has been lauded as a potential "silver bullet" in the face of climate change, but the dynamics of ecosystems are complex and depend on geographic and climatic realities (Popkin 2019). For example, in California, to best plan for a resilient landscape able to sequester the most carbon in the future climatic reality, grasslands can be more impactful than trees (Dass et al. 2018). In the midwestern United States, wetlands are the biosequestration powerhouse habitat, and the largest gains can be made in converting agricultural lands to wetlands or to the respective natural land cover (Nahlik and Fennessy 2016).

Beyond the ecological and environmental complexities, biosequestration as a carbon mitigation strategy is inextricably intertwined with social and environmental justice inequities that must additionally be acknowledged. The negative impacts of climate change, caused in part by $\mathrm{CO}_{2}$ emissions, will be a burden disproportionately experienced by low-income communities and communities of color (Miranda et al. 2011). Creative solutions involving biosequestration, as they relate to landownership, land stewardship, and open access to natural lands and urban green spaces must be developed with communities to be successful and inclusive.

In the following report, we inventory all U-M landholdings, linking the plant communities and habitats to their potential carbon storage, estimated range of carbon sequestration rates, and their economic values (social cost of carbon and valuation of all ecosystem services provided (de Groot et al. 2012; Costanza et al. 2014). Specifically, we used aerial imagery and geographic information systems (GIS) to analyze existing land use and land cover (LULC) of all U-M owned lands (see Appendix C). At a subset of U-M properties (U-M School for Environment and Sustainability [SEAS] properties), our team conducted field-based vegetation surveys (see Appendix C) to provide ground truth data for accuracy assessments of the LULC classification maps and the carbon storage and biosequestration rate calculationswhich can vary significantly based on specificity of the input data (i.e., by land cover compared to by tree, which requires data for each individual tree's species, age, and size; Jana et al. 2009). Having found similar results (high accuracy) comparing methodologies, we continued with our LULC map methodology across all U-M sites (beyond SEAS properties) to calculate baseline carbon storage, biosequestration rate ranges, and their current market valuations by habitat type as reported in the literature (see Appendix C).

Throughout the project, we investigated the approach of comparable institutions to maximize biosequestration (Appendix D) and had discussions with internal and external partners (Appendix E) to inform our approach, determine relevant ongoing projects, and understand perceived benefits and barriers to the recommendations made by our team. Here we present cost-effective, inclusive, high-impact recommendations to inform U-M's approach to carbon neutrality goals. 
Key Findings

- We must first acknowledge that U-M is located on the traditional territory of the Anishinaabe and Shoshoni people.

- U-M owns approximately 8,640 hectares (ha) of land, $99.4 \%$ of which is in Michigan.

- Annual biosequestration for all U-M landholdings is estimated at 45,000-86,000 metric tons $(\mathrm{t})$ of carbon dioxide equivalent $\left(\mathrm{CO}_{2} \mathrm{e}\right)$ per year $(\mathrm{yr})$, valued at $\$ 2.2$ million to $\$ 4.3$ million annually ( $\$ 50 / \mathrm{t}$, social cost of carbon).

- U-M landholdings are estimated to store 1.37 million to 3.68 million metric tons of carbon.

- U-M natural lands provide ecosystem services valued at \$250 million annually.

- Converting 36 ha of agricultural land at Harper Preserve (SEAS property) to a wetland and enhancing 51.5 ha of wetlands at Matthaei Botanical Gardens (MBG) could increase biosequestration rates at these properties by $257 \%$ and $48 \%$, respectively.

- Planting trees to achieve $60 \%$ canopy cover on each campus can increase biosequestration by $753-1,618 \mathrm{tCO}_{2} / \mathrm{yr}$.

- Creating green infrastructure including rain gardens, native gardens, urban meadows, bioswales and extensive green roofs on campus is invaluable for the promotion of carbon neutrality efforts and community engagement.

- U-M actions to increase biosequestration could lead to significant positive impact for communities. In Flint, approximately $40 \%$ of residents live below the poverty line and disproportionately experience climate crises tied to carbon emissions.

- Creative solutions involving biosequestration related to land ownership, stewardship, and access to natural lands and urban green spaces must be developed with communities to be successful and inclusive.

\section{Prioritized Recommendations Summary}

1. U-M owned natural lands should be protected and expanded and their ecosystem service contributions should be included in land-use decision-making processes.

2. Enhance biosequestration potential on natural lands through restoration and enhancement.

3. Cultivate physical and cultural campus landscapes with ecologically and environmentally friendly practices prioritizing justice, inclusivity, and transparency.

\section{Priority \#1 Recommendation: Protect natural lands}

The conservation of U-M owned natural lands (over 7,000 ha, representing $85 \%$ of U-M lands; Table 1, see Appendix $F$ for details by site) ensures protection of ecosystem services they provide while valuing their carbon storage contribution and biosequestration potential. Though important to note that natural landholdings warrant protection and conservation in their own right, these sites provide a myriad of ecosystem services valued at over $\$ 250$ million annually (Costanza et al. 2014, converted to 2019\$; Table 1). Ecosystem services accounted for include regulating services (e.g., biosequestration of carbon, air quality, and climate regulation), habitat (e.g., gene pool protection), provisioning services (e.g., raw materials, genetic resources), and cultural services (e.g., recreation) (de Groot et al. 2012; Costanza et al. 2014; see Appendix $\mathrm{F}$ for full list).

\section{A. University of Michigan-owned natural lands should be protected in perpetuity} U-M natural lands are estimated to store 1.25 million to 3.37 million t carbon and additionally sequester carbon at a rate of $41,000-78,500 \mathrm{tCO}_{2} \mathrm{e} / \mathrm{yr}$ (Table 1). This biosequestration rate is valued at a range of $\$ 2.1$ million to $\$ 3.9$ million annually $(\$ 50 / t$ California market price of social carbon (California Environmental Protection Agency 2017, converted to 2019\$; Table 1). These 
lands contribute $90 \%$ of carbon sequestration and $92 \%$ of carbon storage for all U-M landholdings.

Table 1. Carbon stored and biosequestration rates in U-M natural lands by property type. Area and land cover classifications based on GIS assessment, carbon storage estimates, and biosequestration rates based on literature. See Appendix $F$ for detailed information by site and Appendix $C$ for methods.

\begin{tabular}{|c|c|c|c|c|c|}
\hline U-M property type & $\begin{array}{c}\text { Area } \\
\text { (ha) }\end{array}$ & $\begin{array}{l}\text { Carbon stored } \\
\text { (t C) }\end{array}$ & $\begin{array}{l}\text { Annual } \\
\text { biosequestration } \\
\text { rate }\left(\mathrm{tCO}_{2} \mathrm{e} / \mathrm{yr}\right)\end{array}$ & $\begin{array}{c}\text { Annual } \\
\text { biosequestration value } \\
\left(\$ 50 / \mathrm{CO}_{2} / \mathrm{yr}\right)\end{array}$ & $\begin{array}{c}\text { Annual } \\
\text { ecosystem service } \\
\text { value* }^{*}\end{array}$ \\
\hline SEAS properties & 721 & $116,196-310,136$ & $3,807-7,219$ & $\$ 190,363-\$ 360,928$ & $\$ 22,957,498$ \\
\hline MBGNA & 345 & $54,652-219,798$ & $1,804-3,969$ & $\$ 90,207-\$ 198,443$ & $\$ 25,487,703$ \\
\hline UMBS & 4093 & $712,594-1,733,850$ & $23,279-42,963$ & $\$ 1,163,959-\$ 2,148,147$ & $\$ 107,978,127$ \\
\hline $\begin{array}{l}\text { Reserves and } \\
\text { preserves }\end{array}$ & 2123 & $353,803-1,072,382$ & $12,059-23,803$ & $\$ 602,968-\$ 1,190,132$ & $\$ 88,873,822$ \\
\hline Camps & 99 & $12,335-38,287$ & $371-744$ & $\$ 18,525-\$ 37,177$ & $\$ 4,064,734$ \\
\hline
\end{tabular}

${ }^{*}$ Costanza et al. 2014 , converted to $2019 \$$.

Biosequestration and carbon storage estimates are based on GIS work to calculate land cover and habitat-based carbon accounting estimates in the literature (see Appendices $\mathrm{C}$ and $\mathrm{F}$, Table 1). Continued valuation of sites can be conducted in this manner, updating financial valuations each year for estimated contributions and values (de Groot et al. 2010). Alternatively, for the most accurate readings, university researchers can conduct long-term studies on carbon storage and sequestration rates using carbon towers, soil cores, vegetation growth, and decomposition rate to better inform the literature and identify U-M as a leader and innovator in carbon accounting in urban ecosystems. Work to this degree of specificity in natural systems, using similar methods, is already underway at U-M Biological Station (UMBS), led by a team of U-M researchers.

Financially, continued non-development on these lands will not increase current baseline costs. However, sustainable management practices to optimize ecological and ecosystem service outcomes will incur additional costs and/or reallocation of funds or person hours (outlined in recommendation 2). The biosequestration occurring at these sites can be used as a counterbalance against emissions in other arenas without needing to invest in offsets.

\section{B. Valuation of ecosystem services should be included in U-M expansion planning} Combined, U-M natural area landholdings provide more than $\$ 250$ million in ecosystem services annually, including regulating services, habitat provisioning, and cultural services (Costanza et al. 2014; Table 1). Ecosystem services are rarely included in cost-benefit analyses of new construction or development, leading to projects where costs far outweigh the benefits (Costanza, de Groot, and Farberk 1997). Projected losses can be compared to current offset market costs or potential land purchase values to counteract biosequestration losses (among other ecosystem services). Inclusion of ecosystem costs can assist in campus expansion planning (with projected $2 \%$ expansion per year) to best evaluate inherent values of undeveloped lands.

We recommend any development and/or expansion planning consider the ecosystem service values of undeveloped lands - including those within urban systems - to fully acknowledge the inherent and economic values of open spaces. 


\section{Purchase and protect undeveloped sites contiguous with current natural landholdings with prioritization of wetland ecosystems}

In addition to being vital carbon sinks, wetlands also provide critical ecosystem services related to biodiversity, wildlife habitat, water quality, and flood regulation (Junk et al. 2013). Wetlands contain a disproportionate amount of the Earth's total soil carbon, holding between $20 \%-30 \%$ of the estimated 2,500 petagrams $(\mathrm{Pg})$ (2.5 trillion t) of global soil carbon (Lal 2008) despite occupying only $5 \%-8 \%$ of its land surface (Mitsch et al. 2012). However, the rates of loss and deterioration of global wetlands are accelerating due to human development (i.e., more than $35 \%$ loss in less than 50 years, three times faster than forests; UNFCCC 2018); therefore, it is crucial to conserve and protect these unique ecosystems.

We have identified two freshwater inland wetland properties for sale adjacent to St. Pierre Wetlands, a field research property managed by U-M SEAS (see Appendix G for details). According to the Huron River Watershed Council (HRWC), these properties are the last intact wetland prairie ecosystems in Hamburg Township that remain unprotected (see HRWC Bioreserve Site Assessments, Appendix G). In the first six months of ownership, ecosystem services provided by these sites will outweigh the listed purchase cost (Table 2; Costanza et al. 2014). We recommend U-M purchase these properties and partner with community groups and local and regional conservation organizations to maintain and protect these sites in perpetuity.

Table 2. Freshwater inland wetland properties contiguous with U-M SEAS properties recommended for purchase. Area and land cover classifications based on GIS assessment by the biosequestration team, carbon storage estimates and biosequestration rates based on literature estimations (see Appendix C). For detailed information per property, see Appendix F.

\begin{tabular}{|c|c|c|c|c|c|c|}
\hline Property & $\begin{array}{l}\text { Area } \\
\text { (ha) }\end{array}$ & $\begin{array}{l}\text { Carbon } \\
\text { stored (t C) }\end{array}$ & $\begin{array}{c}\text { Annual } \\
\text { biosequestration } \\
\text { rate }\left(\mathrm{tCO}_{2} \mathrm{e} / \mathrm{y}\right)\end{array}$ & $\begin{array}{c}\text { Annual } \\
\text { biosequestration } \\
\text { value }\left(\$ 50 / \mathrm{tCO}_{2} / \mathrm{y}\right)\end{array}$ & $\begin{array}{c}\text { Annual } \\
\text { ecosystem } \\
\text { service value* }\end{array}$ & $\begin{array}{c}\text { Listed } \\
\text { purchase } \\
\text { price }\end{array}$ \\
\hline Hooker Rd & 20.5 & $2,000-13,600$ & 64-185 & $\$ 3,200-9,250$ & $\$ 2.2$ million & $\$ 1.9$ million \\
\hline Whitewood & 28.5 & $4,500-21,700$ & $142-343$ & $\$ 7,100-17,150$ & $\$ 2.9$ million & $\$ 599,000$ \\
\hline
\end{tabular}

${ }^{*}$ Costanza et al. 2014, converted to $2019 \$$.

${ }^{*}$ It was indicated to the biosequestration team that an agreement to protect the property in perpetuity would result in sale commissions being waived.

\section{Priority \#2 Recommendation: Restore and enhance natural lands}

We recommend three synergistic approaches to manage natural lands to optimize biosequestration: A) convert a large tract of leased-out agricultural land to wetland; B) provide resources for restoration and enhancement efforts on natural lands; and C) provide resources for long-term management of natural and restored lands.

A. Convert agricultural land to wetland A large tract of agricultural land owned by U-M should be converted to wetland. Harper Preserve (Figure 1), an off-campus SEAS property (Figure C2), contains $\sim 36$ hectares of agricultural land currently leased to farmers in the local community using conventional farming practices. At the end of the current lease cycle, if there is not a superseding interest to reestablish this land as a sustainable or regenerative agriculture research site and outdoor learning lab (in partnership with the SEAS program and interested internal research teams), we recommend conversion to a constructed free surface area wetland to maximize carbon sequestration and long-term carbon storage. 
Agriculture accounted for $10 \%$ of total US greenhouse gas (GHG) emissions in 2016 (Congressional Research Service 2018), whereas wetlands can sequester more carbon per area than any other land cover type in the Midwest (Nahlik and Fennessy 2016) and serve as a sink for GHGs when evaluated over longer time scales (Brix, Sorrell, and Lorenzen 2001; Mitsch et al. 2013).

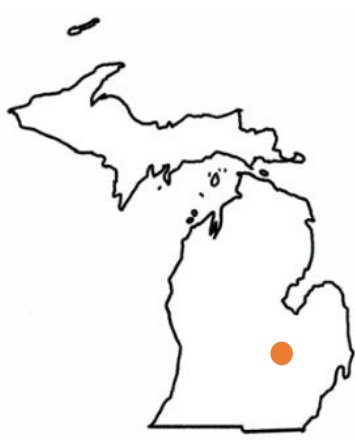

A
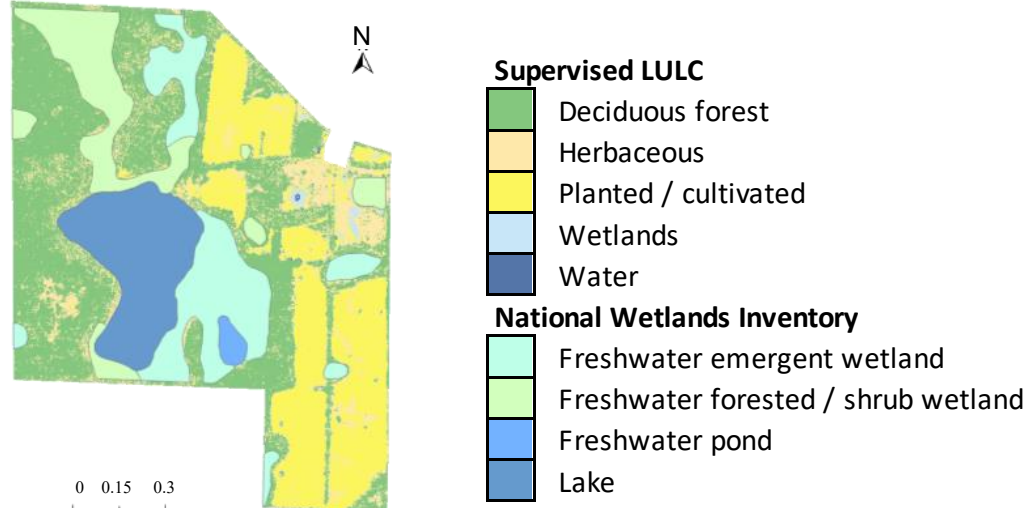

Figure 1. Current LULC of Harper Preserve with National Wetlands Inventory data. A) Map of Michigan with location of Harper Preserve designated with a point; and B) Map of Harper Preserve with agricultural land (Planted/cultivated) in yellow. Data Sources: ESRI 2020; U.S. Fish and Wildlife Service 2020.

Biosequestration rates measured in natural, freshwater wetlands vary but have been estimated at up to $9.8 \mathrm{tCO}_{2} \mathrm{e} / \mathrm{ha} / \mathrm{yr}$ for herbaceous wetlands (Bernal and Mitsch 2012; see Appendix F). By converting Harper Preserve's 36 hectares of agricultural land to wetland, it is estimated that U-M could increase biosequestration at this site by an average of $7.15(4.54-9.80) \mathrm{tCO}_{2} \mathrm{e} / \mathrm{ha} / \mathrm{yr}$, or $257.4 \mathrm{tCO}_{2} \mathrm{e} / \mathrm{yr}$ based on biosequestration rates of agricultural lands and constructed wetlands (de Klein and van der Werf 2014; see Appendix F).

The cost of constructed wetlands varies depending on initial site conditions, total wetland area/drainage area, and initial design costs but is estimated at Harper Preserve to be approximately \$2.3 million (Environmental Protection Agency 2000; Tyndall and Bowman 2016), while operating and maintenance costs are estimated to be approximately $\$ 1,205$ per hectare per year (Environmental Protection Agency 2000). Annualized over a 100-year time frame, this is an annual cost of $\$ 24,205$. Average biosequestration rate of this wetland is estimated at $257.4 \mathrm{tCO}_{2} \mathrm{e} / \mathrm{yr}$, at a cost of $\$ 94.03$ per $\mathrm{tCO}_{2} \mathrm{e} / \mathrm{yr}$ (see Appendix $\mathrm{F}$ ). Therefore, this project would be valued at $\$ 12,870$ annually (California Environmental Protection Agency 2017) for biosequestration (converted to $2019 \$$ ). Annualizing over a 100 -year time frame is relevant when considering costs in relation to benefits of wetlands and forested areas (Nabuurs et al. 2007). Estimated planning and design time for the constructed wetland would be one year, with construction time to last six months. Performance of the constructed wetland is expected to reach optimal levels five years after construction (Environmental Protection Agency 1994).

B. Provide resources for restoration and enhancement efforts on natural lands To conserve and maximize biosequestration potential, we recommend additional staffing for the management of off-campus SEAS properties and additional staffing and equipment at MBG (see Figure C3 for LULC map of MBG; see recommendation 2C for estimated costs). While wetland and forested areas hold some of the highest biosequestration rates (Bernal and Mitsch 
2012; Ma et al. 2020; see Appendix F), continual habitat maintenance, including restoration, is needed to reach biosequestration potentials.

We recommend enhancement of all U-M wetland areas to improve biosequestration and planting 100 trees each year for a decade to enhance biosequestration in mixed forest landscapes. We recommend continued removal of invasive plant species to increase plant biodiversity and increase ecosystem services provided by the lands. In addition, we recommend increasing the capabilities of UMBS to continue serving as a carbon cycle research site by providing resources for staffing. This will help make U-M a leader in carbon sequestration research.

Enhancement efforts at all wetland sites at MBG are estimated to increase biosequestration rates by $252.35 \mathrm{tCO}_{2} \mathrm{e} / \mathrm{yr}$, or $48 \%$. This is based on restoring 51.5 hectares from a biosequestration rate of $5.24 \mathrm{tCO}_{2} \mathrm{e} / \mathrm{ha} / \mathrm{yr}$ (low estimate) to a biosequestration rate of 10.14 $\mathrm{tCO}_{2} \mathrm{e} / \mathrm{ha} / \mathrm{yr}$ (midpoint of estimate) based on improved biosequestration rates of natural wetlands (Bernal and Mitsch 2012; see Appendix F). Wetland enhancement projects are less expensive than creation or restoration projects by approximately a factor of three (King and Bohlen 1994). With our estimate of a constructed wetland at an annual cost of $\$ 672.3 /$ ha over a 100 -year time frame, this suggests a cost of an enhanced wetland to be $\$ 224.1 /$ ha annually. Thus, enhancing wetland at MBG is estimated to cost $\$ 11,541.1$ annually over a 100 -year time frame. Biosequestration rates are estimated to increase by $252.35 \mathrm{tCO}_{2} \mathrm{e} / \mathrm{yr}$, which is at an estimated cost of $\$ 45.73$ per $\mathrm{tCO}_{2} \mathrm{e} / \mathrm{yr}$. This project would be valued at $\$ 12,617.5$ (California Environmental Protection Agency 2017) for annual biosequestration, which is lower than the cost of the project.

Enhancement efforts in forested sites through a 10-year tree planting would be equivalent to approximately 5 hectares of increased canopy cover. This would result in an estimated average increase in biosequestration rate of 46 (33-59) $\mathrm{tCO}_{2} \mathrm{e} / \mathrm{yr}$ after 10 years (see Appendix $\mathrm{F}$ ). Planting trees could be done rather inexpensively, as MBG has indicated that they can plant trees small and have the expertise to maximize tree survival, with each planted tree on average costing \$27. Equipment and materials to plant and to maintain a tree until active management is not necessary is $\$ 200$. If 100 trees are planted each year for 10 years, the cost of this project is $\$ 2,270$ annualized over 100 years. Biosequestration rates are estimated to increase by 46 $\mathrm{tCO}_{2} \mathrm{e} / \mathrm{yr}$ at an estimated cost of $\$ 49.34$ per $\mathrm{tCO}_{2} \mathrm{e} / \mathrm{yr}$. This project would be valued at $\$ 2,300$ for annual biosequestration (California Environmental Protection Agency 2017), which is approximately the cost of the project.

Removal of invasive plant species at MBG increases biodiversity, and empirical data repeatedly illustrate the positive correlation between biodiversity and ecosystem function across a multitude of service metrics (i.e., productivity, resilience, stability, and resistance to invasion are all inextricably linked to biosequestration potentials of the plant community) within many habitats and regions (e.g., Tilman, Isbell, and Cowles 2014; Hooper et al. 2005). Essentially, conservation and ecosystem service provisioning can go hand in hand when both outcomes are optimized in restoration and management planning. Costs vary, but additional staffing and equipment (see this recommendation, part $\mathrm{C}$ ) will provide needed resources for this effort.

UMBS has two AmeriFlux towers to measure carbon flux. U-M faculty, students, and researchers from across the country conduct climate research at UMBS. A long-term research project is the Forest Resilience Threshold Experiment (FoRTE), which investigates forests' ability to sequester carbon especially in a changing climate. While UMBS is not suggested as a site where biosequestration could be increased significantly (as it is already heavily forested), it 
is a natural laboratory (see Figure C4 for LULC map of UMBS). A researcher from the Department of Energy commented that "UMBS could uniquely accommodate a large-scale experimental manipulation. There really aren't that many places, given land size restrictions, where that's possible" (Kalejs 2018).

\section{Provide resources for long-term management of natural and restored lands}

The off-campus SEAS properties comprise over 720 hectares and require their own natural areas manager, with an additional manager for other SEAS facilities such as the Dana Building. MBG has over 340 hectares of land, composed mostly of natural lands. Providing resources and staff could help maximize long-term biosequestration at MBG by enhancing wetlands, planting trees, and removing invasive species. If the wetlands, particularly constructed wetlands, are not being managed and designed properly, they could become GHG sources, considering methane production is also a natural behavior of wetlands (Rosli et al. 2017). Management practices can act to favor net carbon fixation and accumulation while also limiting $\mathrm{CH}_{4}$ emissions in both natural and created wetlands as much as possible (Brix, Sorrell, and Lorenzen 2001).

By providing resources for long-term management of enhanced and restored lands, U-M would ensure that annual biosequestration rates estimated here are likely to be reached. Dedicated staff and equipment are needed to advance carbon neutrality goals on U-M lands and ensure maximization of long-term biosequestration. In addition to the costs outlined in 1) and 2) for specific projects, additional natural areas staff are needed for SEAS properties, MBG, and UMBS. We recommend 1.0 FTE for SEAS properties, 2.0 FTEs for MBG, 0.5 FTE for UMBS, and $\$ 30,000$ for student interns and work-study students for MBG. The cost of 1 FTE is approximately $\$ 100,000$ per year, so staff cost for long-term management of restored lands is $\$ 350,000$ per year. Transportation costs of $\$ 25,000$ annually are needed for student workers as well as students/faculty/staff to allow easy engagement with MBG as part of the campus. Additionally, a one-time equipment cost of $\$ 50,000$ is needed for MBG.

\section{Priority \#3 Recommendation: Cultivate physical and cultural campus landscapes with ecologically and environmentally friendly practices prioritizing justice, inclusivity, and transparency}

We recommend that $\mathrm{U}-\mathrm{M}$ take steps to cultivate the campus landscape to increase the biosequestration potential of each campus while being conspicuous examples of U-M's commitment to carbon neutrality. These steps are: A) plant trees on U-M campuses to increase canopy cover to $60 \%$, B) replace remaining turfgrass with environmentally friendly alternatives, and C) create purposeful green infrastructure (rain gardens, native gardens, bioswales, and green roofs). To highlight the importance of these ecologically, environmentally, and carbonfriendly practices, we advocate a significant increase in signage and other communications in addition to providing student opportunities through courses and workshops. Financially, initial costs for construction should be considered; however, land management costs on campus lands overall are estimated to be lower.

\section{A. Plant trees to increase canopy cover}

Forests have the largest terrestrial carbon stocks of any land cover type and are an important component of the global carbon cycle. Globally, carbon sequestration in forests accounts for 4.1 $\mathrm{Pg} \mathrm{C} / \mathrm{yr}$ (4.1 trillion $\mathrm{tCO}_{2} \mathrm{e} / \mathrm{yr}$ ) (Pan et al. 2011), the equivalent of $30 \%$ of all fossil fuel emissions in 2010 (Gren and Zeleke 2016; IPCC 2014). Forests in the Great Lakes region have carbon sequestration rates between 5.46-11.73 $\mathrm{tCO}_{2} \mathrm{e} / \mathrm{ha} / \mathrm{yr}$ (Curtis et al. 2002), but studies on reforestation of disturbed areas have shown greater short-term sequestration rates between 8.8-18.33 $\mathrm{tCO}_{2} \mathrm{e} / \mathrm{ha} / \mathrm{yr}$, as soil carbon stocks recover over a 20-year period (Niu and Duiker 2006). Trees should be planted on each campus in an effort to reach $60 \%$ canopy cover. 
Benefits of this action include greater carbon sequestration, increased cooling by negating the urban heat island effect (Ziter et al. 2019), and support for increased biodiversity.

Currently, the Ann Arbor campus has $48 \%$ canopy cover, Dearborn has $50 \%$ canopy cover, and Flint has 18.5\% (see Appendices $\mathrm{C}$ and $\mathrm{H}$; Table 3 ). In order to increase canopy cover across all campuses, U-M needs to plant an additional 138 hectares in trees, with approximately 28,000 trees required, assuming each tree eventually achieves a $7.6 \mathrm{~m}$ canopy diameter. Converting 138 hectares of the total 180 hectares of turfgrass cover across the three campuses to forest cover would increase the sequestration potential of these areas by $753-1,618 \mathrm{tCO}_{2} \mathrm{e} / \mathrm{yr}$ (see Appendix F). To ensure no net loss of trees occurs once trees have been planted, canopy cover would have to be monitored regularly by U-M Grounds using GIS or direct measurements (e.g., large, mature trees that are lost should be replaced by planting multiple small, young trees).

Total cost to plant 28,000 trees on campuses is approximately $\$ 22.4$ million, or $\$ 800 /$ tree (cost estimated by U-M Grounds), which covers the cost of the trees in addition to the time and materials required by Grounds departments. Annualized over 100 years, this is a cost of $\$ 224,000$ annually. Annual sequestration would reduce costs by $\$ 37,650-\$ 80,900$ annually in terms of the social cost of carbon (California Environmental Protection Agency 2017). Annual ecosystem services provided by converting turfgrass to forest cover is valued at $\$ 532,474 / \mathrm{yr}$ (de Groot et al. 2012; converted to $2019 \$$ ). Thus, this is an overall net positive investment.

Table 3. Percentage of tree canopy cover and turfgrass cover of each U-M campus as calculated by GIS. See Appendix C.

\begin{tabular}{|c|c|c|c|}
\hline U-M campus & Area (ha) & Tree canopy cover (\%) & Turfgrass cover (\%) \\
\hline Ann Arbor & 1012.0 & $48.3 \%$ & $29.2 \%$ \\
\hline Dearborn & 70.5 & $49.9 \%$ & $14.9 \%$ \\
\hline Flint & 31.5 & $18.5 \%$ & $23.8 \%$ \\
\hline
\end{tabular}

B. Replace turfgrass with environmentally friendly alternatives

Turfgrass on campus, most of which has been in place much longer than the 30-year life span in which it can sequester carbon, should be converted to either a no-mow low-growing fescue or taken out of mowing and seeded over to become "meadow." Both options will continue to sequester carbon at similar rates to other turfgrass systems but greatly reduce the emissions due to management from mowing, fertilizing, irrigating, and applying pesticides. Turfgrass systems have been shown to have limited carbon sequestration potential, and in the long term, even become carbon sources when in place longer than 30 years (Selhorst and Lal 2012; Qian and Follett 2002). New turfgrass systems can sequester carbon at a rate of 0.92-7.4 $\mathrm{tCO}_{2} \mathrm{e} / \mathrm{ha} / \mathrm{yr}$. However, as soil organic carbon builds in the soil, the rate of sequestration declines (Zirkle, Lal, and Augustin 2011). While the species of turfgrass can ameliorate this somewhat (i.e., tall fescue has been shown to have a greater carbon sequestration potential than Kentucky Bluegrass; Qian, Follett, and Kimble 2010), the continued mowing and fertilization required of many turfgrass systems eventually overwhelm soil organic carbon accumulation.

Converting turfgrass systems would eliminate the $21.7 \mathrm{tCO}_{2} / \mathrm{yr}$ (see Appendix C) emitted by mowers every year and reduce the impact of fertilization, decreasing emissions from (up to) 24 $\mathrm{tCO}_{2} / \mathrm{yr}$ to zero (see Appendix C), following a conversion to compost-only fertilization (see 
Appendix C). These recommendations would have a high visual impact as well, showing the student body that steps are being taken toward carbon neutrality. Costs to convert current turfgrass land cover into low-maintenance eco-grass through reseeding would be about $\$ 550,000$ (129,000 lbs of eco-grass mix, Prairie Moon Seed, Winona, MN), while simply taking current turfgrass areas out of the mowing rotation would be very low cost. Turfgrass areas can also be seeded over with native wildflowers to add beauty and increase biodiversity in the campus landscape (Perrow and Davy 2002). Significantly lower maintenance costs would result by eliminating or greatly reducing mowing, fertilizer use, and watering (Dernoeden et al. 2003).

C. Create green infrastructure: rain gardens, native gardens, bioswales, and green roofs Green infrastructure, including rain gardens, native gardens, urban meadows, bioswales, and extensive green roofs, should be incorporated into existing campus infrastructure and all future development and stormwater management plans. These cost-effective installations would help increase carbon sequestration while also assisting to improve water quality and stormwater management (Table 4). In addition, green infrastructure provides other socioeconomic and environmental benefits, including reducing air and noise pollution, decreasing the urban heat island effect, improving building energy efficiency, and providing wildlife habitat to increase biodiversity (Odefey et al. 2012; Meerow and Newell 2017).

Beyond providing beneficial ecosystem services, green infrastructure projects would serve as prominent examples of U-M's commitment to becoming a more sustainable and carbon neutral institution. U-M Grounds and Facilities, local municipalities, and the community at large will need to be consulted on all projects to identify areas where green infrastructure and stormwater management would be most beneficial. In Michigan cities, interviews with residents show widespread support for green infrastructure solutions, but residents were concerned about governance and maintenance (Carmichael, Danks, and Vatovec 2019). See Appendix I for costbenefit resources for green infrastructure in comparison to conventional methods.

Table 4. Biosequestration rates, values, and estimated costs by green infrastructure type.

\begin{tabular}{|c|c|c|c|c|c|}
\hline Green infrastructure type & $\begin{array}{c}\text { Annual } \\
\text { biosequestration } \\
\text { rate } \\
\left(\mathrm{tCO}_{2} \mathrm{e} / \mathrm{ha} / \mathrm{yr}\right)\end{array}$ & $\begin{array}{c}\text { Annual } \\
\text { biosequestration } \\
\text { value } \\
\left(\$ 50 / \mathrm{CO}_{2} \mathrm{e} / \mathrm{ha} / \mathrm{yr}\right)\end{array}$ & $\begin{array}{l}\text { Estimated } \\
\text { installation } \\
\text { cost per/sq } \\
\mathrm{ft}(2019 \$)^{*}\end{array}$ & $\begin{array}{c}\text { Estimated } \\
\text { maintenance } \\
\text { cost per/sq ft } \\
(2019 \$)^{\star \star}\end{array}$ & $\begin{array}{l}\text { Estimated } \\
\text { life span }\end{array}$ \\
\hline Rain gardens & $25.17 \pm 22.8^{6}$ & $\$ 1,258.5 \pm \$ 1,140$ & $\$ 10-\$ 40$ & $\$ 0.41-\$ 0.80^{2}$ & $25-50$ years \\
\hline Native gardens/urban meadows & $1.24-4.94^{1}$ & $\$ 62-\$ 247$ & $\$ 0.02-\$ 0.18^{2}$ & $\$ 0.04-\$ 0.11^{2}$ & 100 years \\
\hline Bioswales & $2.86 \pm 0.08^{6}$ & $\$ 143 \pm \$ 4$ & $\$ 7.2-\$ 28.60^{2}$ & $\$ 0.08-\$ 27^{2}$ & $25-50$ years \\
\hline Extensive green roofs & $6.9^{5,6}$ & $\$ 345$ & $\$ 10^{4}$ & $\$ 0.81-\$ 1.62^{4}$ & $25-50$ years \\
\hline
\end{tabular}

${ }^{*}$ Costs are provided per sq ft to align with the cost-benefit tools and resources in Appendix I.

** Once native plants are fully established, little maintenance will be required.

${ }^{1}$ Odefey 2012; ${ }^{2}$ CNT 2009; ${ }^{3}$ Costanza et al. 2014; ${ }^{4}$ Environmental Protection Agency 2014; ${ }^{5}$ Getter et al. $2009 ;{ }^{6}$ Kavehei et al. 2018.

\section{Additional considerations for all recommendations}

We do not wish to discount the importance of the remaining information needed to implement the recommendations proposed. However, there are many similarities in our recommendations in regard to follow-up and considerations required. Therefore, Table 5 serves as a quick reference. Equity and justice considerations do differ between our recommendations, and so we detail those here. Additionally, the most significant implementation challenges we see for our recommendations are a potential lack of coordination between groups identified in 
organizational structure considerations or a lack of communication regarding the projects undertaken and their purpose (Table 5).

- Land acknowledgements should be made in partnership with tribal leadership and U-M experts. They should be visible and accessible, especially at events and ceremonies.

- Access to natural lands and green spaces is correlated with socioeconomic standing, but these spaces provide cultural benefits, and accessibility is important.

- Explicit consideration could be made for women- and minority-owned businesses to provide services for the construction and enhancement of natural lands.

- Planting trees provides urban heat island mitigation, stormwater retention, and air quality improvements.

- Long-term management of natural and restored lands could reflect a land ethic prioritization and be an example of the U-M cultural value system.

- Green infrastructure designs should improve biosequestration potential and ecosystem services and promote public education and engagement while also being sustainable, accessible, and inclusive.

Table 5. Additional considerations for metrics and tracking, organizational structure and internal partners, campus culture, and transferability and external partners as related to the biosequestration recommendations. An $x$ indicates our designation that the consideration or partnership is a requirement and a / indicates a suggested consideration or partnership.

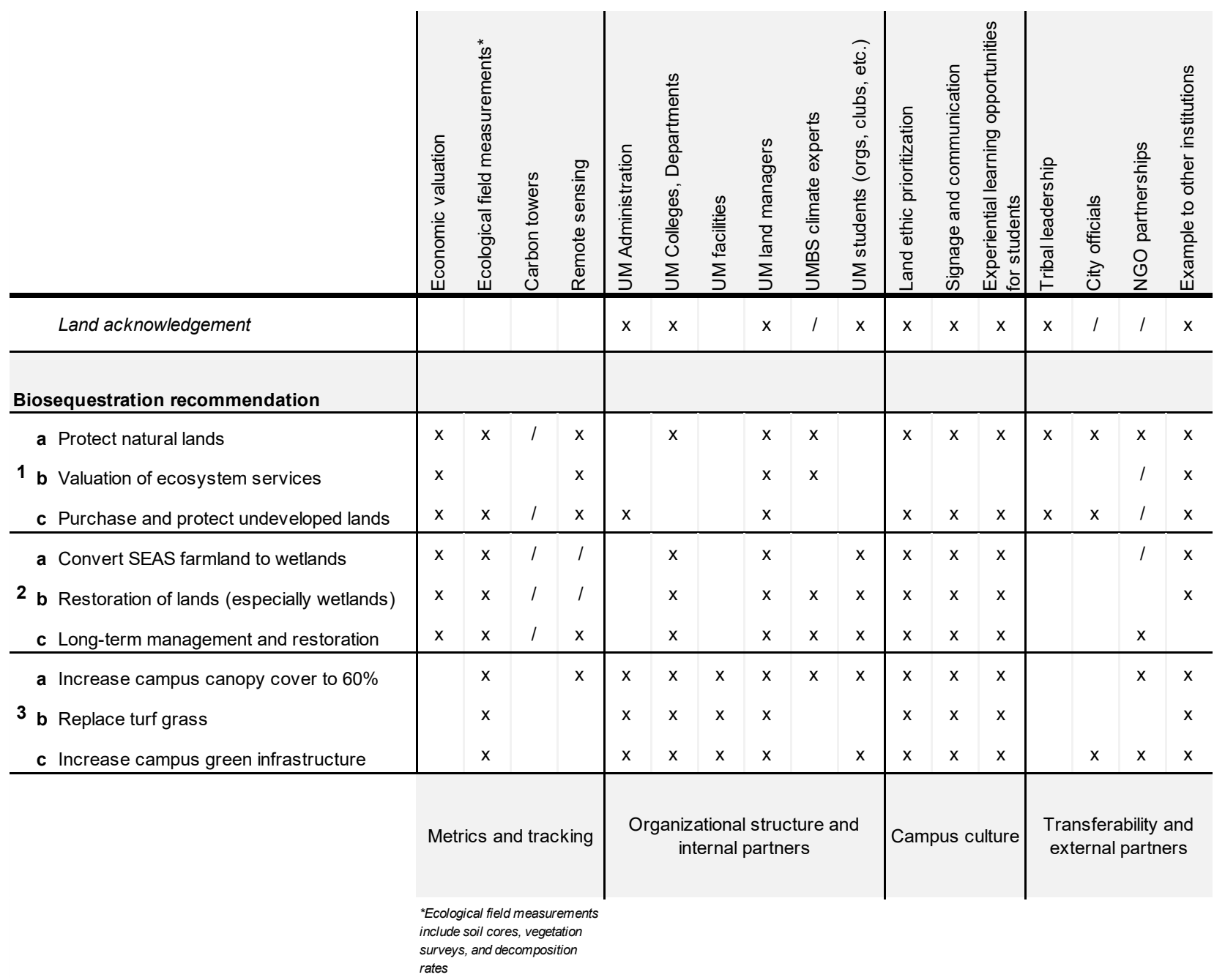


Additional analyses, knowledge gaps, next steps to catalyze work

Land acknowledgement: gather information on previous attempts and begin respectful engagement of tribal leadership working through existing partnerships. Recommendation \#1: land managers need to be part of planning process, U-M funds and budgetary constraints to purchase land and hire new positions, potential partnerships with local NGOs and community groups should be explored. Recommendation \#2: bandwidth of the land managers, need for more staffing support, whether restoration will be completed in house or outsourced.

Recommendation \#3: identify local nurseries for appropriate genetic source material and to boost local economy with consideration for women- and minority-owned businesses. 


\section{APPENDICES}

\section{Appendix A - Land acknowledgement resources}

\section{Examples of land acknowledgement statements from comparable institutions}

Michigan State University

Ohio State University

\section{UM-LSA EBB Land acknowledgement statement UMBS Indian Point Land Acknowledgement}

Example U-M email signature line land acknowledgement

The University of Michigan is located on the territory of the Anishinaabe people. In 1817, the Ojibwe, Odawa, and Bodewadami Nations made the largest single land donation to the University of Michigan, ceded through the Treaty at the Foot of the Rapids so that their children could be educated. These lands were later sold, and formed the original corpus of the university's endowment, founded on the principle of educating a diverse population. A plaque commemorating this ceding of lands and quoting this educational purpose is in place on the Diag, the central outdoor area in the middle of Central Campus, where the campus community gathers in times of joy, grief, and protest by way of practicing the tools of democracy.

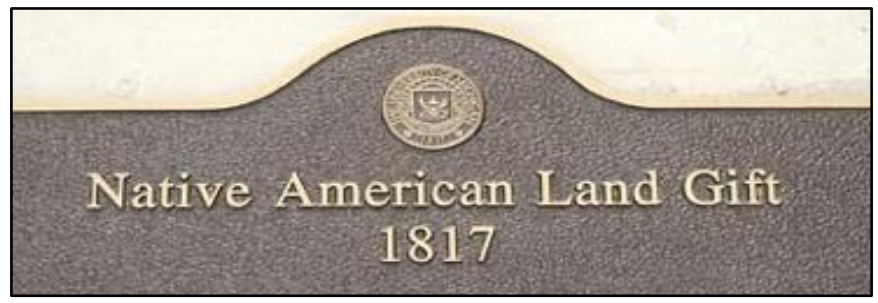

Figure A1. Plaque located on campus commemorating the ceding of lands. Text of the plaque: This plaque commemorates the grant of lands from the Ojibwe (Chippewa), Odawa (Ottawa), and Bodewadimi (Potawatomi), through the Treaty of Fort Meigs, which states that "believing they may wish some of their children hereafter educated, [they] do grant to the rector of the Catholic church of St. Anne of Detroit ... and to the corporation of the college at Detroit, for the use of the said college, to be retained or sold, as the said rector and corporation may judge expedient ..." The rector was Gabriel Richard, a founder and first vice president of the corporation of the college, chartered by the territorial legislature as the University of Michigania in 1817. These lands were eventually sold to the benefit of the University of Michigan, which was relocated to Ann Arbor in 1837.

\section{History of U-M land transfer}

Treaty of Fort Meigs, Article 16 describes the grant of lands by Chippewa, Ottawa, and Potawatomi

U-M originally passed The Waiver of Tuition for North American Indians Act in 1976 
Members of the Anishinaabek Tribes (Ojibwe, Odawa, and Potawatomi) sought instruction for their children in the text of the treaty and were aboriginal to the areas associated with the school's founding. Additional Tribes who signed the treaty and have aboriginal ties to southeast Michigan are most notably the Wyandot (a.k.a. Huron) who were also aboriginal to the Detroit area, including the Huron River Valley. They were historically on friendly terms with the Anishinaabek Tribes.

\section{Additional history of select U-M properties}

SEAS Property-Ringwood Forest

- Lumbered in 1862, U-M received in 1930

- There is historical information about indigenous tribes in Saginaw county, but so far no land acknowledgement directly relating to the U-M owned property

Chase S. Osborn Preserve (Sugar Island)

- Chippewa county, Bay Mills Indian Community owns some reservation land on the island and Native Americans make up $1 / 3$ of the population (Eastern Upper Peninsula Planning)

Missaukee Preserve

- Book from 1920 describing some of the history of this preserve

- Main object of preserve was to preserve remarkable Indian earthworks

- Preserve was a gift, and earthworks were acquired through a purchase of 120 acres

- Preserve later increased to 240 acres

UMBS

- $\quad$ Exists on land (like most of Michigan) once occupied by indigenous people

- Indian Point lies on land near the site of a tragic event termed the burnout, which was a "forced relocation of the Burt Lake Band of Chippewa and Ottawa Indians in 1900"

- $\quad$ Burt Lake burnout report and letter-Has more details on the acquisition of UMBS lands near the burnout location

Resources that may help the university engage with the indigenous community MACPRA-Michigan Anishinaabek Cultural Preservation \& Repatriation Alliance

- Established in 2000, consists of eleven Indian Tribes and two State Historic Tribes

- Main goal is to protect and preserve all cultural resources past present and future, including: former habitation areas of ancestors, burials, grave goods, and other traditional cultural properties

- Representatives include those in the Bay Mills Indian Community and Burt Lake Band of Ottawa and Chippewa Indians

MACPRA members include:

Federally Recognized Tribes:

- Bay Mills Indian Community (Michigan)

- Grand Traverse Band of Ottawa and Chippewa Indians (Michigan)

- Hannahville Indian Community (Michigan)

- Keweenaw Bay Indian Community, Lake Superior Band of Chippewa Indians (Michigan)

- Lac Vieux Desert Band of Lake Superior Chippewa Indians (Michigan)

- Little River Band of Ottawa Indians (Michigan) 
- Little Traverse Bay Bands of Odawa Indians (Michigan)

- Match-E-Be-Nash-She-Wish Band of Pottawatomi Indians (Gun Lake Tribe) (Michigan)

- Nottawaseppi Huron Band of Potawatomi Indians (Michigan)

- Pokagon Band of Potawatomi Indians (Michigan and Indiana)

- Saginaw Chippewa Indian Tribe of Michigan

- Sault Sainte Marie Tribe of Chippewa Indians (Michigan)

- State Historic Tribes:

- Burt Lake Band of Ottawa and Chippewa Indians (Michigan)

- Grand River Band of Ottawa Indians (Michigan)

\section{Native American Graves Protection and Repatriation Act}

- US federal law mandates the transfer of Native American human remains, funerary objects, sacred objects, and objects of cultural patrimony that meet the requirements of the law and regulations to the lineal descendants, and Indian Tribes or Native Hawaiian Organizations that are culturally affiliated to them or that have requested them as coming from locations where the requesting Indian Tribe/Native Hawaiian Organization has aboriginal status as determined by the law and regulations.

- Passed in 1990; federally funded museums and institutions must comply with the federal government's NAGPRA law and regulations.

- The University's collections include human remains/funerary objects from (based on current information) 38 states (including Michigan), with (based on current estimates) approximately $70 \%$ of the human remains and approximately $50 \%$ of funerary objects coming from Michigan sites (thus, the University has made the transfer of Native American human remains and funerary objects from NAGPRA-eligible sites in Michigan the first priority).

- Sites and Collections database-includes counties and site names with MNI (minimum \# individuals) and FO (funerary object)

\section{College Horizons}

- Since 1998, non-profit dedicated to increasing the number of Native American, Alaska, and Hawaiian students succeeding in college

- Graduate Horizons Conference at U-M

\section{Ziibiwing Center in Mount Pleasant}

- Mission statement: "This promotes the society's belief that the culture, diversity and spirit of the Saginaw Chippewa Indian Tribe of Michigan and other Great Lakes Anishinabek must be recognized, perpetuated, communicated and supported."

Matthaei Botanical Gardens

- David Michener lighting talk-Indigenous seeds

- Anishinabe Collaborative Garden at Matthaei Botanical Gardens 
Appendix B - Recommendations summary matrix

Figure B1. Recommendation summary matrix for biosequestration impact vs.

\$value/\$cost of recommended projects. Dollar values of biosequestration and ecosystem services included in \$value, while cost included only estimated cost of project in dollars. Bubble color corresponds to overarching priority recommendation number \#1 blue, \#2 green, \#3 orange.

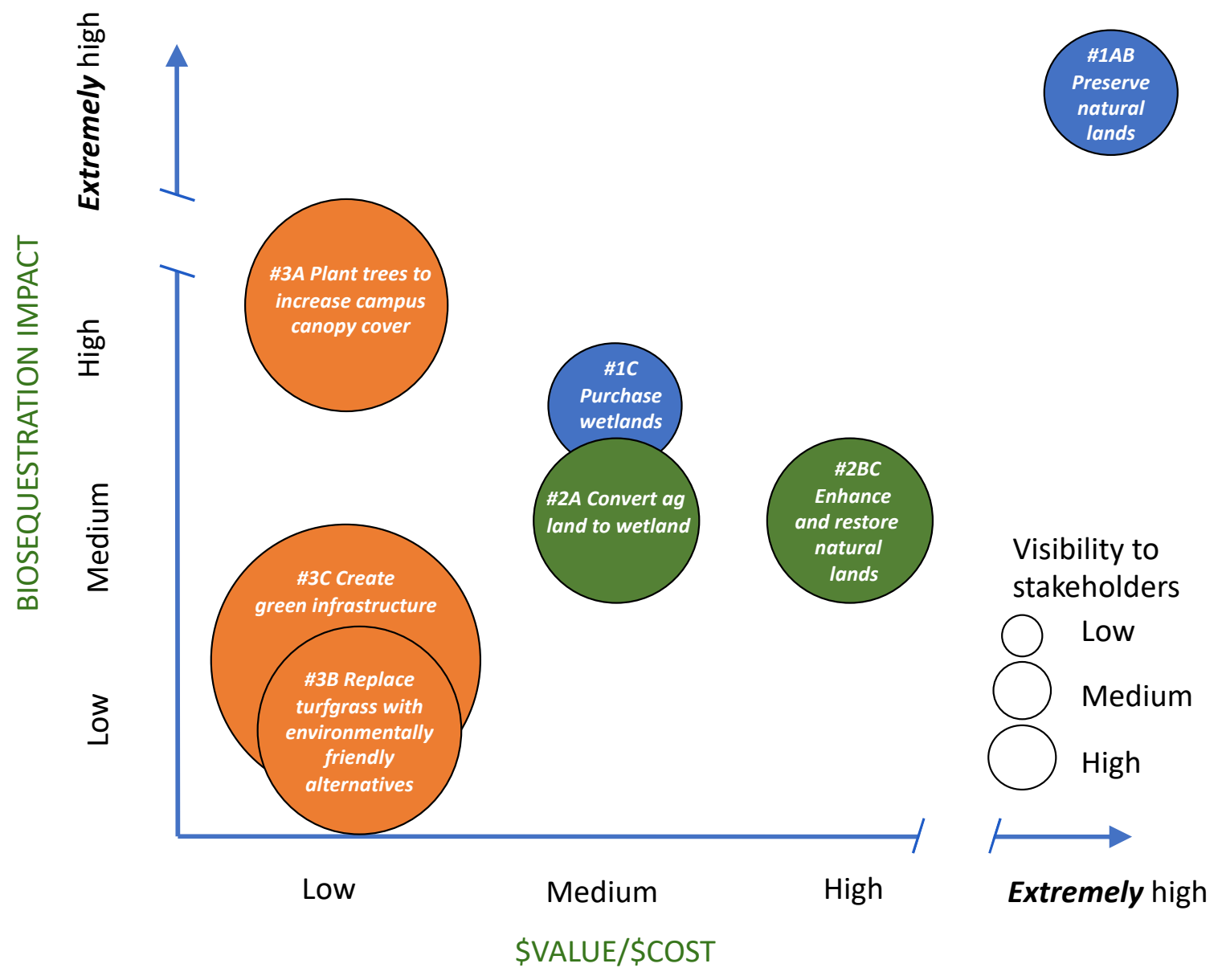




\section{Appendix C - Research methods}

To assess the biosequestration potential for all U-M landholdings, an inventory of the current land use and land cover (LULC) had to be conducted. Using a combination of aerial imagery, GIS data, and vegetation surveys, LULC maps were created for each property to calculate the approximate land cover area by plant community and habitat type. These calculations were used to estimate baseline carbon sequestration rates, carbon storage, and economic value based on the social cost of carbon and ecosystem services provided. Once a baseline was calculated, potential areas could be examined where biosequestration might be improved. The team also researched comparable institutions (Appendix D) and consulted with internal and external partners (Appendix $\mathrm{E}$ ) to better inform our decisions and ensure that recommendations made to the PCCN are the most cost-effective and impactful solutions to help the University of Michigan reach its goal of carbon neutrality.

\section{GIS-Based Methods}

\section{Method 1: Supervised LULC classifications}

To analyze the current land use and land cover (LULC) for all U-M landholdings (30+ properties totaling over 8,640 hectares), we conducted supervised LULC classifications for each property. We first acquired GIS data and imagery files, including property boundary shapefiles, high resolution aerial imagery from Nearmap, and 2018 color infrared imagery from the USDA's National Agriculture Imagery Program (NAIP)(USDA-FSA-APFO Aerial Photography Field Office 2015). Using the NAIP imagery and ArcGIS Pro software, training samples were created for the seven main land cover types from the National Land Cover Database 2011 (NLCD2011) - developed, deciduous forest, evergreen (coniferous) forest, herbaceous, planted/cultivated, wetlands, and water. Nearmap (natural color, leaf-on) and the ESRI Basemap: World Imagery (natural color, leaf-off) were also used to help interpret the different land cover types (ESRI 2020).

Once a sufficient number of training sample polygons were created to represent the full spectral range within each class (e.g., darkest to lightest areas of water), a supervised classification was run using the Support Vector Machine method to create the final LULC outputs for each U-M property (Figure C1). To calculate the area (in hectares) of each of the classified land cover types, the LULC raster was transformed into a polygon feature class. A new field was then created in the attribute table to calculate the areas and summarize the results.

Accuracy assessments for the forested LULC classifications were conducted by comparing the supervised LULC classifications with data from vegetation surveys from five of the SEAS properties (Figure C2; St. Pierre Wetland was not included due to lack of forested land cover). (see Method 5.) Using NAIP 2018 imagery, the GPS points from the field were plotted and $10 \mathrm{~m}$ $\mathrm{x} 10 \mathrm{~m}$ polygon squares were drawn for each vegetation survey plot. Training samples were created for the polygons, which were designated as either deciduous or evergreen forest based on the vegetation surveys and a majority rules method. Accuracy assessments were then run with the ground truth training samples as the reference dataset to create output confusion matrices.

Overall, accuracy of the supervised LULC classifications for the forested land cover types was quite high. For example, with the Newcomb Tract property, the land cover classification for deciduous forest had a $98 \%$ user accuracy, which is the probability that a pixel classified into a given mapped class actually represents that class on the ground. Evergreen forest was slightly 
less at $79 \%$ as it contained more mixed vegetation. Overall, accuracy was $78 \%$, which indicated that this method was valid and could be successfully applied to other U-M properties.

\section{Method 2: Supervised LULC Classifications combined with data from the National Wetlands Inventory}

Unlike forested land cover, supervised LULC classifications for wetlands do not have a high accuracy rate as there is a high probability that forested wetlands will be classified as forest and emergent wetlands will be classified as herbaceous. Therefore, to get a more accurate assessment of the wetlands land cover area for each of the properties, the supervised LULC classifications were rerun without the training samples for wetlands. The latest data from the US FWS National Wetlands Inventory was then downloaded and clipped to the individual property boundary polygons.

After converting the supervised LULC raster files to polygons, the wetlands polygons were erased from the LULC polygons. In the LULC attribute table, a new field was created to calculate the area in hectares for each cover type and summarize the results. The same was done for the wetlands polygons to find the area of each wetland type (freshwater forested/shrub and freshwater emergent). For the final map output, the wetlands polygon layer was overlaid onto the supervised LULC classification (Figure C2). This method was then applied to all U-M properties, including Matthaei Botanical Gardens (MBG; Figure C3) and U-M Biological Station (UMBS; Figure C4).
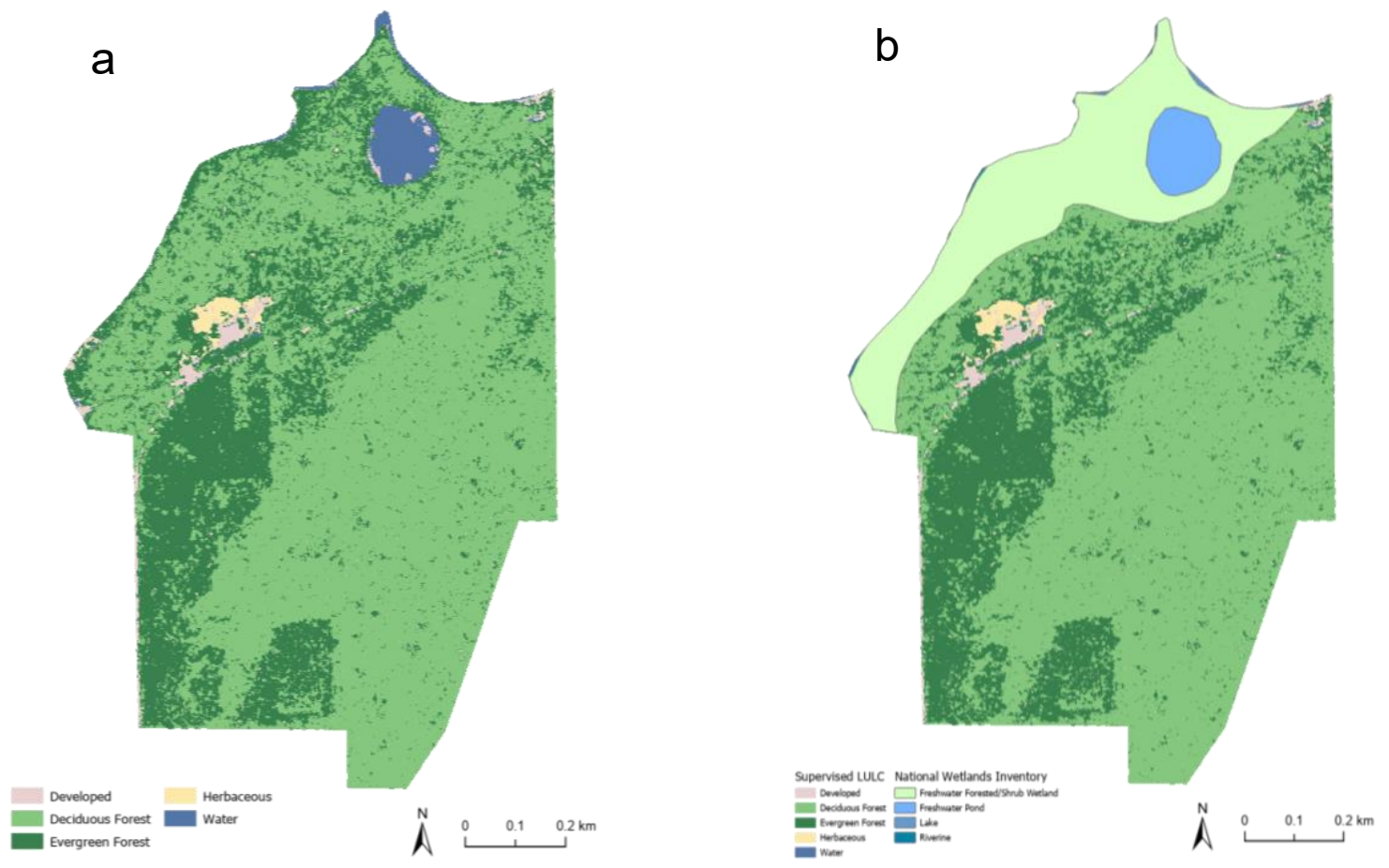

Figure C1. Land use land cover classifications of Newcomb Tract, Webster Township, Washtenaw County, MI, illustrating classifications using a) Method 1: Supervised LULC classification, and b) Method 2: Supervised LULC with National Wetlands Inventory data (Data Sources: ESRI, NAIP 2018, US FWS National Wetlands Inventory). 


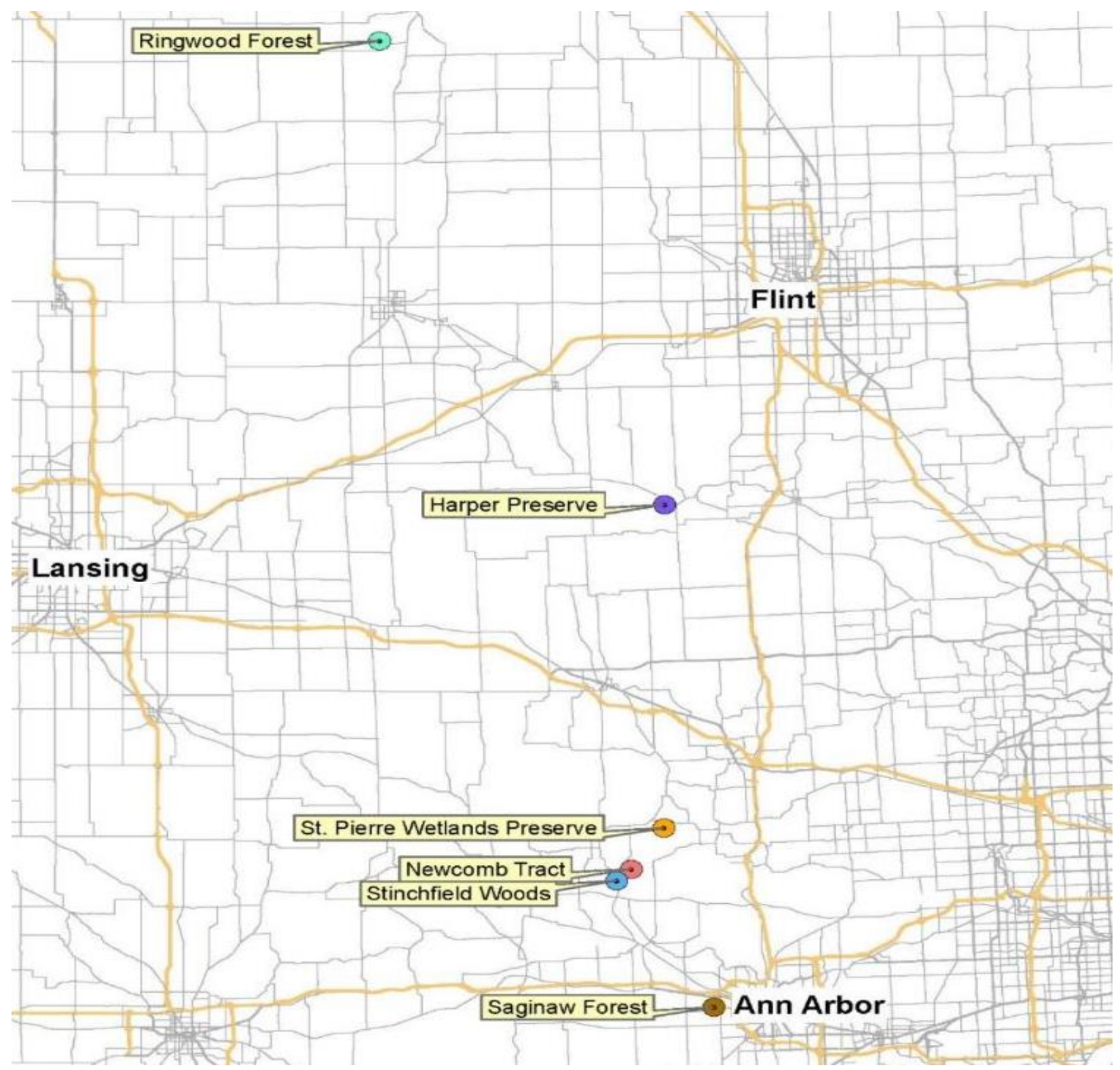

Figure C2. Locations of the six U-M SEAS properties (Source: SNRE Properties Committee PowerPoint Presentation to Faculty 2016). 

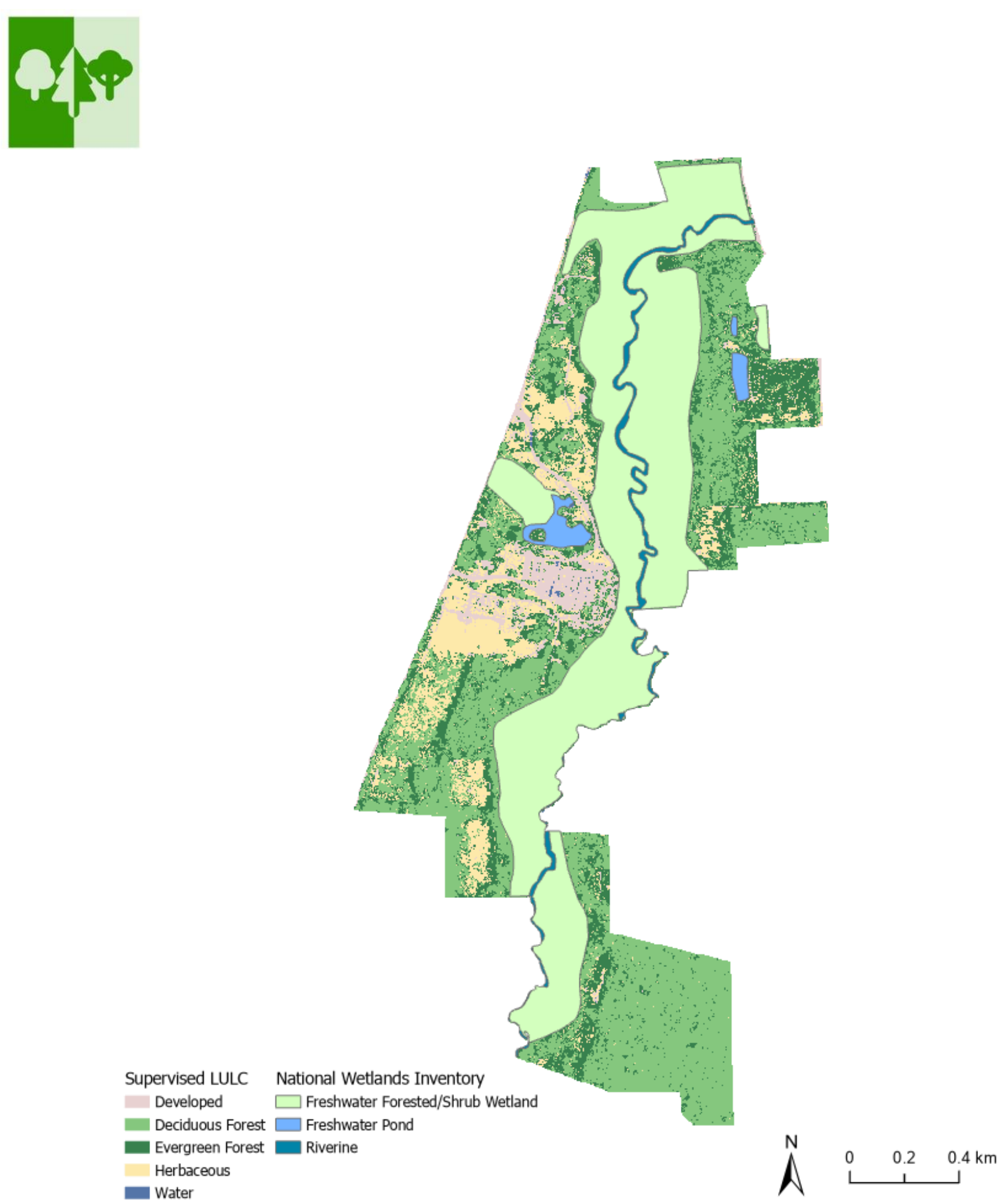

Data Sources: ESRI, NAIP 2018, US FWS National Wetlands Inventory. Projection/Datum: WGS 1984 Web Mercator Auxiliary Sphere. Map Layout by Lara O'Brien, April 22, 2020.

Figure C3. Current LULC of Matthaei Botanical Gardens, Ann Arbor, Washtenaw County, MI, with data from the National Wetlands Inventory (Data Sources: ESRI, NAIP 2018, US FWS National Wetlands Inventory). 

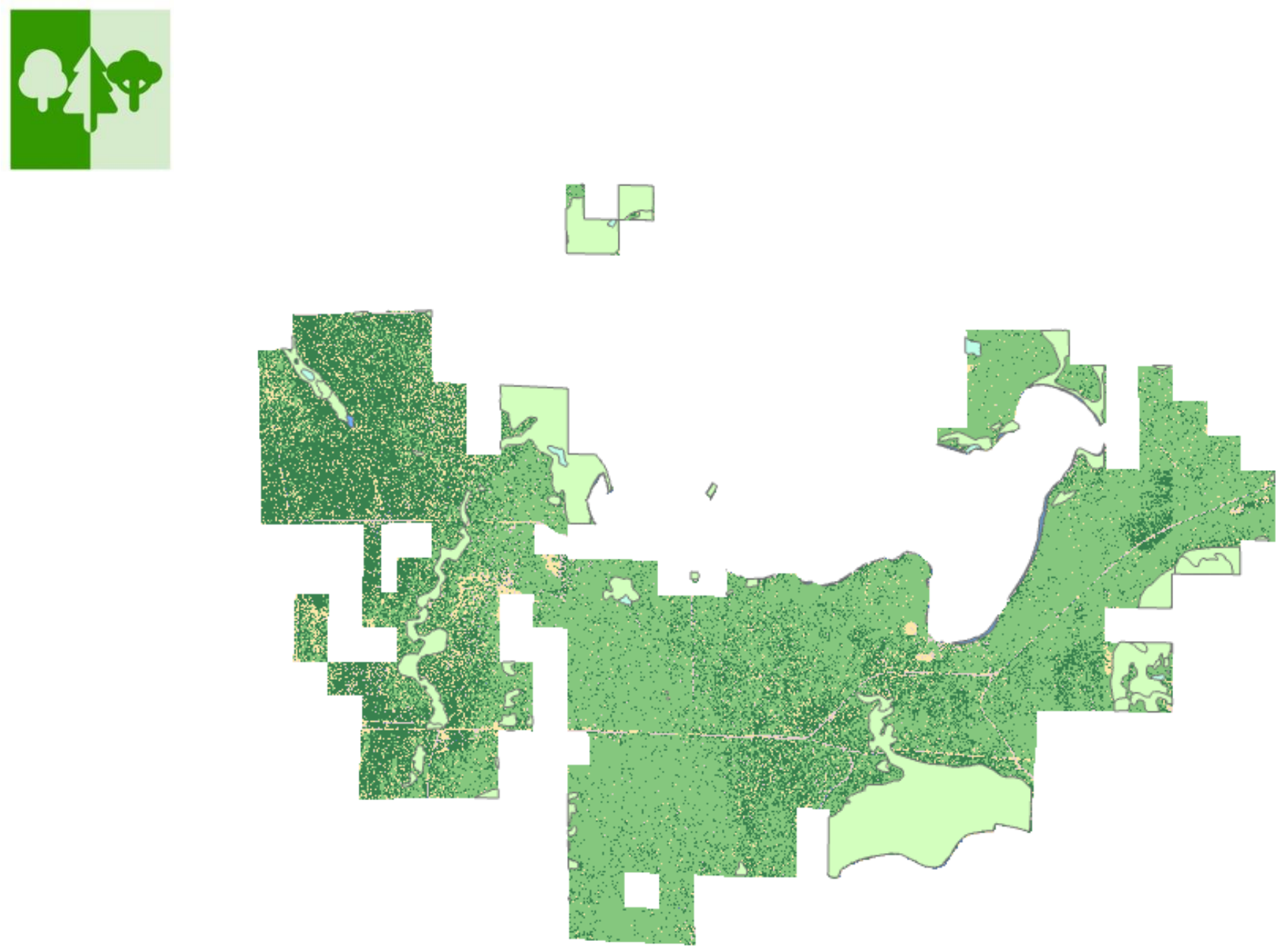

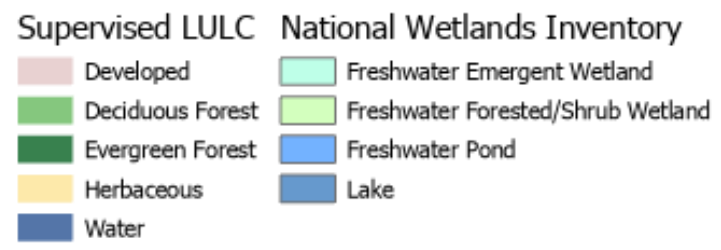

Data Sources: ESRI, NAIP 2018, US FWS National Wetlands Inventory. Projection/Datum: WGS 1984 Web Mercator Auxiliary Sphere. Map Layout by Lara O'Brien, April 22, 2020.
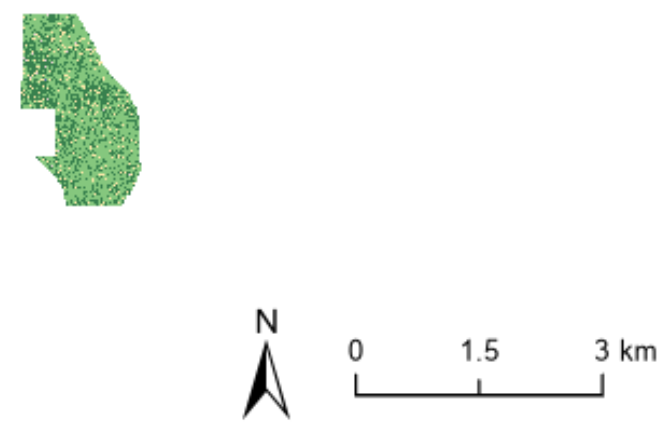

Figure C4. Current LULC of the University of Michigan Biological Station, Pellston, Emmet County, MI, with data from the National Wetlands Inventory (Data Sources: ESRI, NAIP 2018, US FWS National Wetlands Inventory). 
Method 3: Use of Circa 1800 Land Cover Maps and LANDFIRE to assess potential LULC

Because land use and land cover have changed significantly over millennia, understanding appropriate baseline historic land cover is necessary. This will allow for informed recommendations for habitat restoration on U-M properties with carbon sequestration as a prioritized goal. With that goal in mind, the team used the Michigan Land Cover Circa 1800 database and LANDFIRE, a land management tool that provides data layers with potential vegetation types, including biophysical settings (dominant vegetation prior to European colonization and settlement), and environmental site potential (vegetation that could be supported based on the biophysical environment; Figure C5).
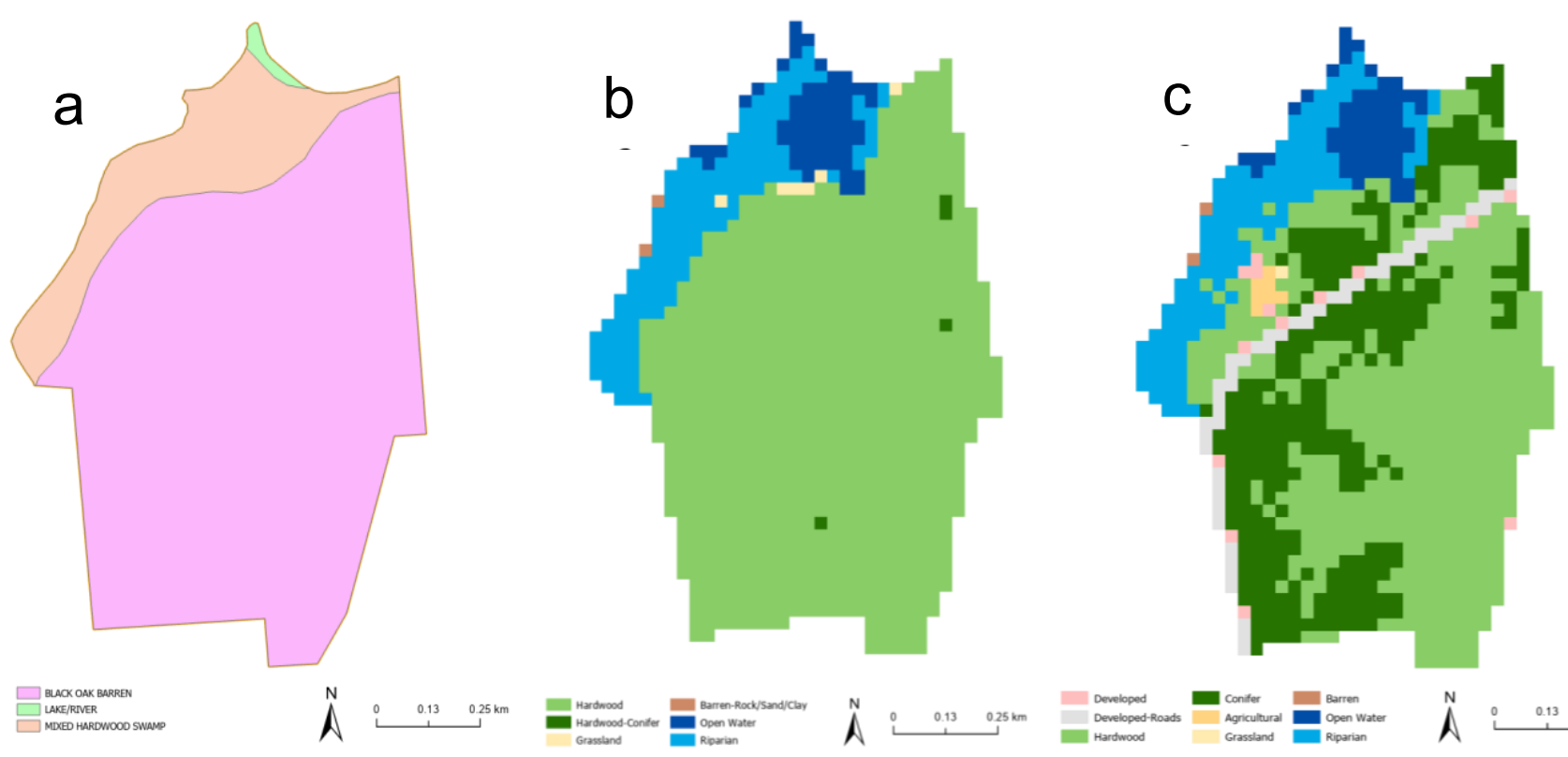

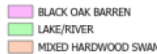
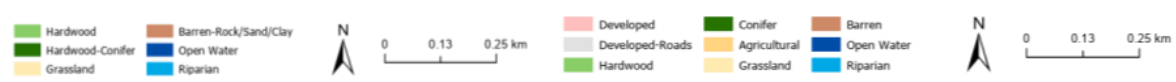

Figure C5. Potential LULC classifications for Newcomb Tract, Webster Township, Washtenaw County, Ml using the following three different datasets: a) Land Cover Circa 1800 (Data Sources: ESRI, Land Cover Circa 1800-Michigan GIS Open Data), b) LANDFIRE Biophysical Settings Data Sources: ESRI, LANDFIRE), and c) LANDFIRE Environmental Site Potential (Data Sources: ESRI, LANDFIRE).

\section{Field-Based Methods}

\section{Method 4: Tree data collection}

Our team calculated carbon storage of trees on all three campuses (Ann Arbor, Flint, and Dearborn). Data regarding trees on the Ann Arbor campus were provided by UM-Ann Arbor Facilities and Operations, tree data on the UM-Flint campus were collected by team members, data for trees on the Dearborn campus were collected by a UM-Dearborn Environmental Science course, and represent a subset of campus. On the UM-Flint campus, team members collected diameter-at-breast-height (DBH) measurements of each tree and identified species. 
Trees were then geolocated using a Trimble field computer (GeoExplorer 6000 series, Trimble Navigation Limited, Sunnyvale, CA).

\section{Method 5: Vegetation Surveys}

To assess carbon storage within woody biomass, vegetation surveys were conducted at each of the five forested SEAS properties. No plots were established at St. Pierre Wetland because there were not enough large trees to warrant the use of woody biomass calculations. Within each property, a series of $10 \mathrm{~m} \times 10 \mathrm{~m}$ plots was established in order to cover a representative sampling of forested land cover types across each property. Before each site visit, rough placements of the plot locations were selected using aerial imagery (Figure C6). Each property contained 8-12 plots divided between deciduous and coniferous cover types. In the field, plots were randomly established by blindly throwing a flag to establish the southwest (SW) corner of the plot. The location of the SW corner was recorded with a Garmin GPS unit. Within the plot, every tree larger than $10 \mathrm{~cm}$ in diameter at breast height (dbh) was counted. Tree species and $\mathrm{dbh}$ were then recorded. Vegetation surveys took place between November 2019 and February 2020.
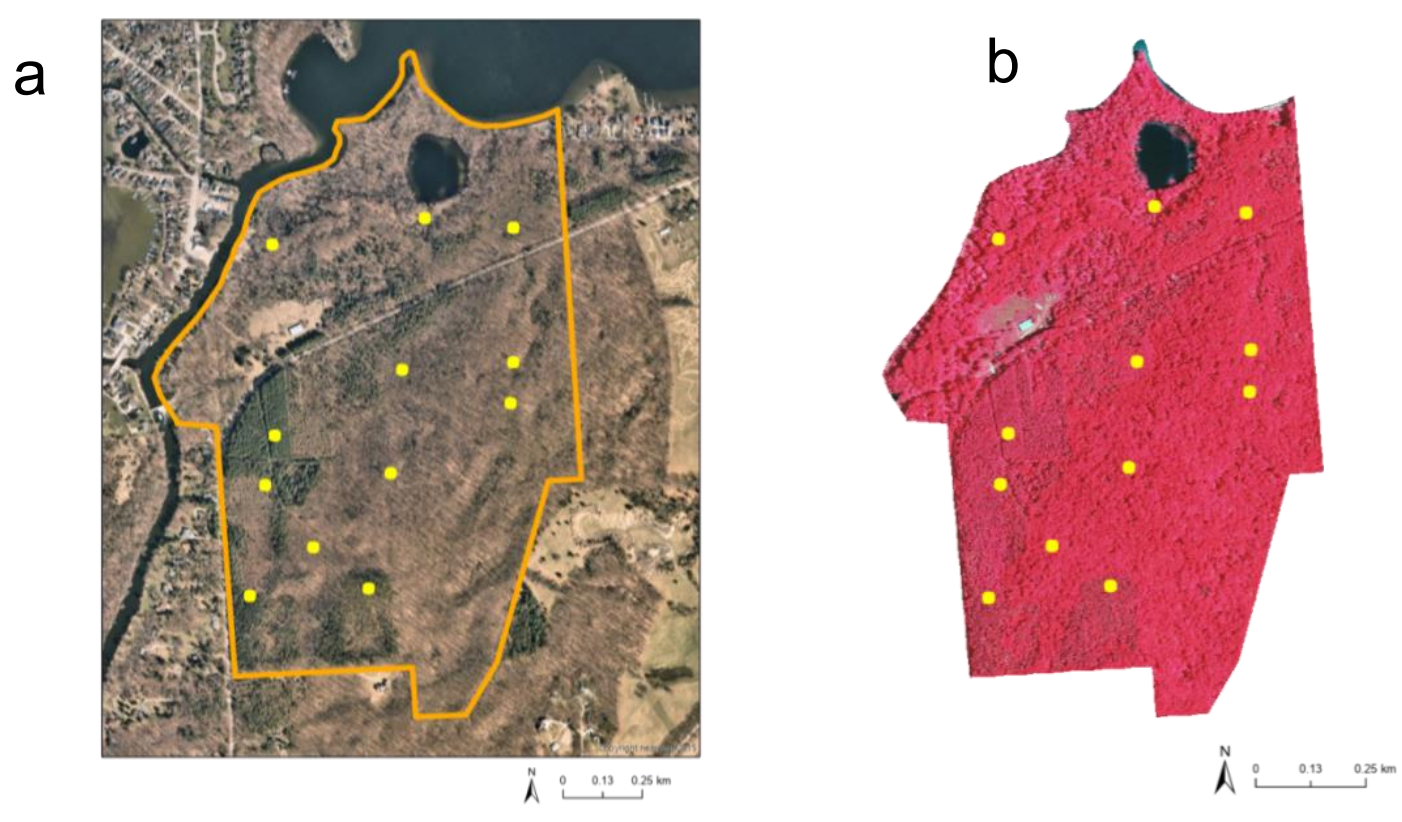

Figure C6. Field sample plots at Newcomb Tract, Webster Township, Washtenaw County, MI, with imagery from a) Nearmap (Data Sources: ESRI, Nearmap), and b) NAIP 2018 (Data Sources: ESRI, NAIP 2018).

\section{Calculation Methods}

\section{Method 6: Carbon storage and sequestration estimations}

The team used a range of carbon storage and sequestration numbers for each cover type identified in the LULC classification maps. These ranges were identified through compiling the maximum and minimum published estimates in literature review, limited to studies that took 
place primarily in the Midwest/Great Lakes region (for ranges of carbon sequestration, see Appendix F). The range of carbon storage and sequestration for each cover type was then multiplied by the total area of that cover type on each U-M property to obtain the total carbon storage and sequestration values across all U-M landholdings. The calculated carbon storage and sequestration rates of each property can be found in Appendix F.

Method 7: Calculations for estimating economic value based on the social cost of carbon and ecosystem services provided

Using a social cost of carbon of $\$ 50$ per metric ton of $\mathrm{CO}_{2}$ (California Environmental Protection Agency 2017), the team calculated the value of biosequestration currently occurring on U-M landholdings. The team also evaluated other ecosystem services provided by U-M properties, according to the economic valuation of ecosystem services done by Costanza et al. (2014).

\section{Comparable Institutions and External Engagement Methods}

\section{Method 8: Peer Benchmarking}

The team has conducted and compiled research on biosequestration methods, including those used by comparable institutions. We conducted web search for comparable institutions in the United States with relevant keywords including biosequestration, carbon sequestration, climate action plans and sustainability. After going through the website, we systemized the information into a chart. We recorded any directly relevant term use, relevant projects, and alternative methods that would contribute to biosequestration of carbon but was not directly mentioned as part of biosequestration. A more detailed description of the approaches was included for each institution researched. We additionally reached out to over 30 people who have been or are currently involved in biosequestration-related projects, and managers of large tracts of U-M owned lands. Biosequestration efforts by comparable institutions can be found in Appendix $D$ and external engagement is further described in Appendix $\mathrm{E}$. 
Appendix D - Peer benchmarking

\begin{tabular}{|c|c|c|c|c|c|c|}
\hline $\begin{array}{c}\text { Institution } \\
\text { name }\end{array}$ & Term usage & Project(s) & $\begin{array}{l}\text { Alternative } \\
\text { methods }\end{array}$ & Description & $\begin{array}{l}\text { Resource } \\
\text { links }\end{array}$ & References \\
\hline $\begin{array}{c}\text { Yale } \\
\text { University }\end{array}$ & $\begin{array}{l}\text { Carbon } \\
\text { Sequestration }\end{array}$ & $\begin{array}{l}\text { - The Yale Carbon } \\
\text { Containment Lab (CC } \\
\text { Lab) } \\
\text { - Urban Meadows } \\
\text { - Rain gardens } \\
\text { - Urban Resource } \\
\text { Initiative, collaboration } \\
\text { with the city on } \\
\text { bioswale projects } \\
\text { - Yale Tree } \\
\text { Management Plan } \\
\text { - Biochar }\end{array}$ & --- & $\begin{array}{l}\text { The CC Lab: } \\
\text { identifying projects } \\
\text { with long-term potential } \\
\text { to reduce net GHG, } \\
\text { focusing on carbon- } \\
\text { storage potential in } \\
\text { natural ecosystems } \\
\text { Landscape management } \\
\text { and tree management } \\
\text { on campus and in the } \\
\text { City of New Haven; } \\
\text { development for } \\
\text { improved biodiversity } \\
\text { and enhanced } \\
\text { environmental quality }\end{array}$ & $\begin{array}{l}\frac{\text { Yale }}{\text { Sustainability }} \\
\underline{\text { The CC Lab }}\end{array}$ & $\begin{array}{l}\text { "Homepage | Yale } \\
\text { Sustainability." n.d. } \\
\text { Accessed April 27, } 2020 . \\
\text { https://sustainability.yale.e } \\
\text { du/. } \\
\text { "Carbon Containment Lab } \\
\text { |." n.d. Accessed April 27, } \\
\text { 2020. } \\
\text { https://carboncontainmentl } \\
\text { ab.yale.edu/. }\end{array}$ \\
\hline $\begin{array}{l}\text { Harvard } \\
\text { University }\end{array}$ & None & $\begin{array}{l}\text { - Harvard Forest } \\
\text { Carbon Studies program } \\
\text { - Two assets of } 4000 \\
\text { acres of forests for } \\
\text { active climate change } \\
\text { research }\end{array}$ & $\begin{array}{l}-75 \% \\
\text { Organic } \\
\text { landscaping } \\
\text { by } 2020 \\
\text { - Sustainable } \\
\text { campus } \\
\text { design for } \\
\text { robust plant } \\
\text { species and } \\
\text { appropriate } \\
\text { biodiversity }\end{array}$ & $\begin{array}{l}\text { Academic projects in } \\
\text { carbon sequestration } \\
\text { through forests and on } \\
\text { campus commitment for } \\
\text { more diverse and robust } \\
\text { plant community }\end{array}$ & $\underline{\text { Harvard }} \underline{\underline{\text { Sustainability }}}$ & $\begin{array}{l}\text { "Nature \& Ecosystems | } \\
\text { Sustainability at Harvard." } \\
\text { n.d. Accessed April 27, } \\
2020 . \\
\text { https://green.harvard.edu/t } \\
\text { opics/nature-ecosystems. } \\
\text { "Sustainability Strategic } \\
\text { Plan | Sustainable Duke." } \\
\text { n.d. Accessed April 27, } \\
\text { 2020. } \\
\text { https://forms.hr.duke.edu/s } \\
\text { ustainability/ssp2017/. }\end{array}$ \\
\hline $\begin{array}{c}\text { Duke } \\
\text { University }\end{array}$ & $\begin{array}{l}\text { Carbon } \\
\text { Offsets }\end{array}$ & $\begin{array}{l}\text { - 10,000 acre Carbon } \\
\text { farming } \\
\text { - Urban Forestry Offset } \\
\text { Tree Planting Program }\end{array}$ & --- & $\begin{array}{l}\text { Enhanced land } \\
\text { management and } \\
\text { conservation practices } \\
\text { to increase carbon }\end{array}$ & $\frac{\underline{\text { Sustainability }}}{\underline{\text { Strategic Plan }}}$ & $\begin{array}{l}\text { "Sustainability Strategic } \\
\text { Plan | Sustainable Duke." } \\
\text { n.d. Accessed April 27, } \\
2020 .\end{array}$ \\
\hline
\end{tabular}




\begin{tabular}{|c|c|c|c|c|c|c|}
\hline & & & & $\begin{array}{l}\text { storage from former } \\
\text { agriculture lands } \\
\text { Planted } 6000 \text { trees } \\
\text { across NC and AZ till } \\
2017 .\end{array}$ & & $\begin{array}{l}\text { https://forms.hr.duke.edu/s } \\
\text { ustainability/ssp2017/. } \\
\text { "Carbon Farming Comes } \\
\text { to North Carolina| } \\
\text { Nicholas School of the } \\
\text { Environment." n.d. } \\
\text { Accessed April 27, 2020. } \\
\text { https://nicholas.duke.edu/n } \\
\text { ews/carbon-farming- } \\
\text { comes-north-carolina. }\end{array}$ \\
\hline $\begin{array}{l}\text { Cornell } \\
\text { University }\end{array}$ & $\begin{array}{l}\text { Carbon } \\
\text { capture and } \\
\text { sequestration }\end{array}$ & $\begin{array}{l}\text { - Mission linked offsets } \\
\text { - Carbon management } \\
\text { - biochar } \\
\text { - Green infrastructure }\end{array}$ & --- & $\begin{array}{l}\text { Conversion of about } \\
4000 \text { acres idle } \\
\text { cropland to forest by } \\
\text { planting trees } \\
\text { Continued estimation } \\
\text { and effort in refining } \\
\text { carbon sequestration } \\
\text { potential } \\
\text { Green infrastructure on } \\
\text { campus, including } \\
\text { bioswale, green roofs, } \\
\text { rain garden sidewalk, } \\
\text { soil mitigation- } \\
\text { restoration } 50 \text { acres of } \\
\text { open space on campus }\end{array}$ & $\begin{array}{l}\frac{\text { Sustainability }}{\text { Report }} \\
\underline{\text { Cornell }} \\
\underline{\text { Sustainability }}\end{array}$ & $\begin{array}{l}\text { University President, } \\
\text { Cornell, and Sustainable } \\
\text { Campus Committee. n.d. } \\
\text { "2013 Climate Action } \\
\text { Plan Update \& Roadmap } \\
\text { 2014-2015." Accessed } \\
\text { April 27, 2020. } \\
\text { www.irondesign.com. } \\
\text { "Sustainability | Cornell } \\
\text { University." n.d. Accessed } \\
\text { April 27, 2020. } \\
\text { https://sustainability.corne } \\
\text { ll.edu/. }\end{array}$ \\
\hline $\begin{array}{l}\text { Massachuset } \\
\text { ts Institute } \\
\text { of } \\
\text { Technology }\end{array}$ & $\begin{array}{l}\text { Carbon } \\
\text { capture and } \\
\text { sequestration }\end{array}$ & $\begin{array}{l}\text { - Green infrastructure } \\
\text { and landscape } \\
\text { innovation }\end{array}$ & $\begin{array}{l}\text { - Non- } \\
\text { biological } \\
\text { carbon } \\
\text { sequestration } \\
\text { projects }\end{array}$ & $\begin{array}{l}\text { Mostly power plant } \\
\text { based carbon capture } \\
\text { and sequestration } \\
\text { projects } \\
\text { Create an ecologically } \\
\text { resilient community }\end{array}$ & $\begin{array}{l}\text { MIT } \\
\underline{\text { Sustainability }}\end{array}$ & $\begin{array}{l}\text { "Resilient Ecosystems | } \\
\text { MIT Sustainability.” n.d. } \\
\text { Accessed April 27, 2020. } \\
\text { https://sustainability.mit.e } \\
\text { du/topic/resilient- } \\
\text { ecosystems\#!landscape. }\end{array}$ \\
\hline $\begin{array}{l}\text { University } \\
\text { of } \\
\text { California, } \\
\text { Berkeley }\end{array}$ & Carbon offset & $\begin{array}{l}\text { - Adopt Urban Forest, } \\
\text { Forest as a percentage } \\
\text { of offset tools }\end{array}$ & --- & $\begin{array}{l}\text { Consider biological } \\
\text { offset projects with } \\
\text { connection to campus } \\
\text { research and a learning } \\
\text { component }\end{array}$ & $\begin{array}{l}\frac{\text { Carbon }}{\text { Neutrality Plan }} \\
\underline{\underline{2025}}\end{array}$ & $\begin{array}{l}\text { Stoll, Kira. 2016. "2025 } \\
\text { Carbon Neutrality } \\
\text { Planning Framework } \\
\text { Physical and } \\
\text { Environmental Planning }\end{array}$ \\
\hline
\end{tabular}




\begin{tabular}{|c|c|c|c|c|c|c|}
\hline & & & & & & $\begin{array}{l}\text { Office of Sustainability } \\
\text { and Energy Carbon } \\
\text { Neutrality Initiative." }\end{array}$ \\
\hline $\begin{array}{l}\text { Northwester } \\
\text { n University }\end{array}$ & None & --- & $\begin{array}{l}\text {-Land use } \\
\text { management }\end{array}$ & $\begin{array}{l}\text { Doubled the use of } \\
\text { adapted plants on } \\
\text { campus }\end{array}$ & $\begin{array}{l}\text { Northwestern } \\
\text { Sustainability } \\
\text { Roadmap }\end{array}$ & $\begin{array}{l}\text { "Northwestern University } \\
\text { Sustainability Road Map - } \\
\text { Built Environment (2017- } \\
\text { 2021)." n.d. }\end{array}$ \\
\hline $\begin{array}{l}\text { University } \\
\text { of } \\
\text { California, } \\
\text { Davis }\end{array}$ & $\begin{array}{l}\text { Sequestration } \\
\text {, offset }\end{array}$ & $\begin{array}{l}\text { - Land use conversion } \\
\text { - Campus urban tree }\end{array}$ & --- & $\begin{array}{l}\text { Expanding urban forest } \\
\text { Conversion of } 380 \text { acres } \\
\text { from agricultural sues } \\
\text { to native bunch grasses }\end{array}$ & $\begin{array}{l}\frac{\text { UC Davis }}{2009-2010} \\
\frac{\text { Climate Action }}{\underline{\text { Plan }}} \\
\frac{\text { UC Davis }}{\underline{\text { Sustainability }}}\end{array}$ & $\begin{array}{l}\text { Kirk, Camille, Bill Starr, } \\
\text { Erdem Savasir, and David } \\
\text { Soares. 2009. "UC Davis } \\
\text { 2009-2010 Climate Action } \\
\text { Plan." } \\
\text { "Sustainable 2nd Century } \\
\text { UC Davis: Climate." n.d. } \\
\text { Accessed April 27, 2020. } \\
\text { https://sustainability.ucdav } \\
\text { is.edu/progress/climate/ind } \\
\text { ex.html. }\end{array}$ \\
\hline $\begin{array}{l}\text { University } \\
\text { of Maryland }\end{array}$ & $\begin{array}{l}\text { Carbon } \\
\text { Sequestration }\end{array}$ & $\begin{array}{l}\text {-Carbon Neutral } \\
\text { grounds and } \\
\text { landscaping } \\
\text { - Offsets from UMD- } \\
\text { owned forests } \\
\text { - Algae-based carbon } \\
\text { capture }\end{array}$ & --- & $\begin{array}{l}\text { Carbon neutral grounds } \\
\text { Quantifying the carbon } \\
\text { sequestration of forests } \\
\text { on university land and } \\
\text { increase tree canopy on } \\
\text { campus } \\
\text { Planting at least } 100 \\
\text { trees per year } \\
\text { Using algae-based } \\
\text { carbon capture } \\
\text { technology to absorb } \\
\mathrm{CO}_{2} \text { from the combined } \\
\text { heat and power plant } \\
\text { emissions }\end{array}$ & $\begin{array}{l}\frac{\text { University of }}{\text { Maryland }} \\
\underline{\text { Climate Action }} \\
\underline{\text { lan }}\end{array}$ & $\begin{array}{l}\text { "Climate Action Plan | } \\
\text { University of Maryland } \\
\text { Office of Sustainability." } \\
\text { n.d. Accessed April 27, } \\
2020 . \\
\text { https://sustainability.umd.e } \\
\text { du/progress/climate- } \\
\text { action-plan. } \\
\text { "IMET Wins \$500K in } \\
\text { Global Innovative Carbon } \\
\text { Use Competition | } \\
\text { University of Maryland } \\
\text { Center for Environmental } \\
\text { Science." n.d. Accessed } \\
\text { April 27, 2020. }\end{array}$ \\
\hline
\end{tabular}




\begin{tabular}{|c|c|c|c|c|c|c|}
\hline $\begin{array}{c}\text { University } \\
\text { of Texas - } \\
\text { Austin }\end{array}$ & None & --- & $\begin{array}{l}\text { - Landscape } \\
\text { Master Plan } \\
\text { - TreeKeeper }\end{array}$ & $\begin{array}{l}\text { TreeKeeper software } \\
\text { catalogs tree on campus } \\
\text { and quantifies } \\
\text { ecosystem services } \\
\text { Landscape restoration } \\
\text { for improved ecosystem } \\
\text { resiliency }\end{array}$ & $\begin{array}{l}\text { Sustainability } \\
\text { Plan } \\
\text { Tree keeper }\end{array}$ & $\begin{array}{l}\text { "Sustainability Master } \\
\text { Plan." } 2016 . \\
\text { "TreeKeeper } 8 \text { System for } \\
\text { University of Texas - } \\
\text { Austin." n.d. Accessed } \\
\text { April 27, 2020. } \\
\text { https://utaustin.treekeepers } \\
\text { oftware.com/. }\end{array}$ \\
\hline $\begin{array}{l}\text { University } \\
\text { of Miami }\end{array}$ & None & & $\begin{array}{l}- \text { Tree } \\
\text { Campus } \\
\text { USA }\end{array}$ & $\begin{array}{l}\text { Landscape architecture } \\
\text { with elements designed } \\
\text { specifically for the } \\
\text { climate and natural } \\
\text { setting }\end{array}$ & $\underline{\text { Green Miami }}$ & $\begin{array}{l}\text { Kirtman, Ben, et al. } \\
\text { "University of Miami } \\
\text { Sustainability Action Plan } \\
\text { Our Sustainability Goals } \\
\text { at a Glance." 2017. } \\
\text { https://stars.aashe.org/. }\end{array}$ \\
\hline $\begin{array}{l}\text { Ohio State } \\
\text { University }\end{array}$ & $\begin{array}{l}\text { Carbon } \\
\text { management } \\
\text { and } \\
\text { sequestration }\end{array}$ & $\begin{array}{l}\text { - Carbon Management } \\
\text { and Sequestration } \\
\text { Center } \\
\text { - Native plant garden }\end{array}$ & --- & $\begin{array}{l}\text { Listed publications- } \\
\text { carbon from farms, } \\
\text { agricultural soils } \\
\text { Transformation of } \\
\text { campus land into native } \\
\text { plant community }\end{array}$ & $\underline{\text { CMASC }}$ & $\begin{array}{l}\text { "Home | CMASC.” n.d. } \\
\text { Accessed April 27, } 2020 . \\
\text { https://cmasc.osu.edu/hom } \\
\text { e. }\end{array}$ \\
\hline $\begin{array}{l}\text { Michigan } \\
\text { State } \\
\text { University }\end{array}$ & $\begin{array}{l}\text { Forest carbon } \\
\text { and climate }\end{array}$ & - Green roofs & $\begin{array}{l}\text {-Curriculum } \\
\text { in forest- } \\
\text { climate } \\
\text { relationships }\end{array}$ & Green roof installation & $\begin{array}{l}\text { Library green } \\
\text { roof }\end{array}$ & $\begin{array}{l}\text { "A New Chapter for a } \\
\text { Library Roof | } \\
\text { Infrastructure Planning } \\
\text { and Facilities." n.d. } \\
\text { Accessed April 27, 2020. } \\
\text { https://ipf.msu.edu/about/n } \\
\text { ews/new-chapter-library- } \\
\text { roof. }\end{array}$ \\
\hline
\end{tabular}




\begin{tabular}{|c|c|c|c|c|c|c|}
\hline $\begin{array}{l}\text { Syracuse } \\
\text { University }\end{array}$ & None & & $\begin{array}{l}\text { - carbon } \\
\text { neutral by } \\
2040 \text { with } \\
\text { Climate } \\
\text { Action Plan }\end{array}$ & $\begin{array}{l}\text { Mentions of updated } \\
\text { plan in terms of campus } \\
\text { expansion }\end{array}$ & $\frac{\text { CAP }}{\text { reformation }}$ & $\begin{array}{l}\text { "Syracuse University to } \\
\text { Reform Climate Action } \\
\text { Plan Years after Release." } \\
\text { n.d. Accessed April 27, } \\
2020 . \\
\text { https://secondnature.org/m } \\
\text { edia/syracuse-university- } \\
\text { to-reform-climate-action- } \\
\text { plan-years-after-release/. }\end{array}$ \\
\hline $\begin{array}{l}\text { University } \\
\text { of Colorado, } \\
\text { Boulder }\end{array}$ & Carbon offset & $\begin{array}{l}\text {-Boulder County's } \\
\text { project }\end{array}$ & --- & $\begin{array}{l}\text { Carbon farming } \\
\text { experiment on } 120 \\
\text { acres of the Campbell } \\
\text { and Quicksilver Farm } \\
\text { (Longmont,CO) }\end{array}$ & $\frac{\underline{\text { Green CU }}}{\underline{\text { Boulder }}} \frac{\underline{\text { County's }}}{\underline{\text { project }}}$ & $\begin{array}{l}\text { "Campus Energy Usage | } \\
\text { Environmental Center | } \\
\text { University of Colorado } \\
\text { Boulder." n.d. Accessed } \\
\text { April 27, 2020. } \\
\text { https://www.colorado.edu/ } \\
\text { ecenter/energyclimate/cu- } \\
\underline{\text { and-energy/campus- }} \\
\text { energy-usage. } \\
\text { "Boulder County's Carbon } \\
\text { Sequestration Project } \\
\text { Reports Limited Impact in } \\
\text { First Year." n.d. Accessed } \\
\text { April 27, 2020. } \\
\text { https://www.denverpost.co } \\
\text { m/2019/10/27/boulder- } \\
\text { carbon-sequestration- } \\
\text { project/. }\end{array}$ \\
\hline $\begin{array}{l}\text { University } \\
\text { of Toledo }\end{array}$ & Sequestration & -Native plant gardens & --- & $\begin{array}{l}3 \text { native plant gardens } \\
\text { on campus maintained } \\
\text { by the Department of } \\
\text { Environmental Sciences } \\
\text { and assisting } 4 \text { other } \\
\text { native gardens on } \\
\text { campus }\end{array}$ & $\frac{\text { Native plant }}{\text { gardens }}$ & $\begin{array}{l}\text { "Native Plant Gardens on } \\
\text { Campus." n.d. Accessed } \\
\text { April 27, 2020. } \\
\text { https://www.utoledo.edu/n } \\
\text { sm/envsciences/guts/garde } \\
\text { n-locations.html. }\end{array}$ \\
\hline
\end{tabular}




\begin{tabular}{|l|l|l|l|l|l|l|}
\hline $\begin{array}{l}\text { University } \\
\text { of Florida }\end{array}$ & Carbon offset & $\begin{array}{l}\text { Land and resource } \\
\text { management }\end{array}$ & --- & $\begin{array}{l}\text { Comprehensive } \\
\text { landscape design and } \\
\text { maintenance of native } \\
\text { ecosystems }\end{array}$ & $\begin{array}{l}\text { Sustainability } \\
\frac{\text { Land and }}{\text { resource }}\end{array}$ & $\begin{array}{l}\text { "UF Sustainability in Land } \\
\text { and Resource } \\
\text { Management } \\
\text { Implementation Plan." n.d. } \\
\text { "Sustainability." n.d. } \\
\text { Accessed April 27, 2020. } \\
\text { https://sustainable.ufl.edu/. }\end{array}$ \\
\hline
\end{tabular}




\section{Appendix E - Internal and external partners consulted}

E1. Internal and external partners consulted by the biosequestration team as well as the partners' organization, role, and focus area/discussion topic.

\begin{tabular}{|l|l|l|}
\hline $\begin{array}{c}\text { Internal or } \\
\text { External }\end{array}$ & \multicolumn{1}{|c|}{ Organization } & Focus Area/Discussion Topic \\
\hline Internal & UM-A2 & UM-A2 property information \\
\hline Internal & UM-A2 & GIS data for MBGNA \\
\hline Internal & UM-Flint & UM-Flint property information \\
\hline Internal & UM-A2 & GIS and remote sensing data \\
\hline Internal & UM-A2 & $\begin{array}{l}\text { Facilitation of introductions to relevant } \\
\text { facilities contacts }\end{array}$ \\
\hline Internal & UM-Dearborn & UM-Dearborn property information \\
\hline Internal & $\begin{array}{l}\text { UM Center for Sustainable } \\
\text { Systems }\end{array}$ & $\begin{array}{l}\text { Projected land use for UM sustainable } \\
\text { ag and foods program }\end{array}$ \\
\hline External & Keep Genesee County Beautiful & Plant recommendations for Flint \\
\hline Internal & $\begin{array}{l}\text { Matthaei Botanical Gardens and } \\
\text { Nichols Arboretum }\end{array}$ & $\begin{array}{l}\text { Engagement strategies around } \\
\text { biosequestration }\end{array}$ \\
\hline Internal & UM-A2 & UM-A2 property information \\
\hline External & Keep Genesee County Beautiful & Plant recommendations for Flint \\
\hline Internal & UM-Flint & $\begin{array}{l}\text { Turfgrass conversion, UM-Flint } \\
\text { property information }\end{array}$ \\
\hline Internal & UM-A2 & UM SEAS property information \\
\hline Internal & $\begin{array}{l}\text { Matthaei Botanical Gardens and } \\
\text { Nichols Arboretum }\end{array}$ & $\begin{array}{l}\text { MBGNA property information and } \\
\text { needs }\end{array}$ \\
\hline
\end{tabular}




\begin{tabular}{|c|c|c|}
\hline Internal & UM-Flint & UM-Flint property information \\
\hline External & $\begin{array}{l}\text { Eastside Improvement } \\
\text { Association of Flint }\end{array}$ & Community perception of trees in Flint \\
\hline Internal & UM-A2 & Field data collection methods \\
\hline External & Keep Genesee County Beautiful & Plant recommendations for Flint \\
\hline Internal & UM-A2 & $\begin{array}{l}\text { DANA Building native garden and } \\
\text { native plantings on campus }\end{array}$ \\
\hline Internal & UM-A2 & Food team land-use considerations \\
\hline External & University of Pittsburgh & $\begin{array}{l}\text { Carbon sequestration, urban tree } \\
\text { mortality, soils carbon calculations }\end{array}$ \\
\hline External & Golden Drake Realty & $\begin{array}{l}\text { Broker for Whitewood and Hooker Rd. } \\
\text { wetland properties }\end{array}$ \\
\hline Internal & UM-A2 & Carbon accounting \\
\hline External & $\begin{array}{l}\text { Currently at UMaine but } \\
\text { discussed role at Harvard }\end{array}$ & Urban campus trees, climate change \\
\hline Internal & $\begin{array}{l}\text { Matthaei Botanical Gardens and } \\
\text { Nichols Arboretum }\end{array}$ & Land acknowledgement \\
\hline Internal & $\begin{array}{l}\text { Matthaei Botanical Gardens and } \\
\text { Nichols Arboretum }\end{array}$ & $\begin{array}{l}\text { Projected land use for UM sustainable } \\
\text { ag and foods program }\end{array}$ \\
\hline Internal & UMBS & $\begin{array}{l}\text { Biosequestration research and carbon } \\
\text { sequestration (storage and rate) } \\
\text { calculations in development at UMBS }\end{array}$ \\
\hline Internal & UMBS & $\begin{array}{l}\text { Biosequestration research and carbon } \\
\text { sequestration (storage and rate) } \\
\text { calculations in development at UMBS }\end{array}$ \\
\hline External & City of Dearborn & $\begin{array}{l}\text { Biosequestration goals and plans in } \\
\text { Dearborn }\end{array}$ \\
\hline
\end{tabular}




\begin{tabular}{|l|l|l|}
\hline Internal & $\begin{array}{l}\text { Matthaei Botanical Gardens and } \\
\text { Nichols Arboretum }\end{array}$ & $\begin{array}{l}\text { MBGNA property information and } \\
\text { needs }\end{array}$ \\
\hline Internal & $\begin{array}{l}\text { Matthaei Botanical Gardens and } \\
\text { Nichols Arboretum }\end{array}$ & $\begin{array}{l}\text { MBGNA property information and } \\
\text { needs }\end{array}$ \\
\hline Internal & $\begin{array}{l}\text { Matthaei Botanical Gardens and } \\
\text { Nichols Arboretum }\end{array}$ & $\begin{array}{l}\text { MBGNA property information and } \\
\text { needs }\end{array}$ \\
\hline Internal & UM-A2 & UM-A2 property information \\
\hline Internal & UM-A2 & Campus GIS data \\
\hline Internal & UMBS & $\begin{array}{l}\text { Biosequestration research and carbon } \\
\text { sequestration (storage and rate) } \\
\text { calculations in development at UMBS }\end{array}$ \\
\hline Internal & UM-A2 & Land acknowledgement \\
\hline Internal and & City of Ann Arbor & $\begin{array}{l}\text { Biosequestration goals and plans in } \\
\text { Ann Arbor }\end{array}$ \\
\hline External & & $\begin{array}{l}\text { Biosequestration research and carbon } \\
\text { sequestration (storage and rate) } \\
\text { calculations in development at UMBS }\end{array}$ \\
\hline Internal & UMBS & UM-A2 property information \\
\hline Internal & UM-A2 &
\end{tabular}


Appendix F - Ecosystem services provided by natural lands

Table F1. Carbon storage, sequestration rates, and value of sequestration and ecosystem services at each U-M property.

\begin{tabular}{|c|c|c|c|c|c|}
\hline $\begin{array}{l}\text { U-M } \\
\text { property }\end{array}$ & $\begin{array}{c}\text { Area } \\
\text { (ha) }\end{array}$ & $\begin{array}{l}\text { Carbon } \\
\text { stored (t } \\
\text { C) }\end{array}$ & $\begin{array}{c}\text { Annual } \\
\text { biosequestration } \\
\text { rate }\left(\mathrm{tCO}_{2} \mathrm{e} / \mathrm{yr}\right)\end{array}$ & $\begin{array}{c}\text { Annual } \\
\text { biosequestration } \\
\text { value } \\
\left(\$ 50 / \mathrm{CO}_{2} \mathrm{e} / \mathrm{yr}\right)\end{array}$ & $\begin{array}{c}\text { Annual } \\
\text { ecosystem } \\
\text { service value } \\
\text { (Costanza et } \\
\text { al. 2014; in } \\
2019 \$ \text { ) }\end{array}$ \\
\hline \multicolumn{6}{|l|}{$\begin{array}{l}\text { Campus } \\
\text { properties }\end{array}$} \\
\hline $\begin{array}{l}\text { UM-Ann } \\
\text { Arbor } \\
\text { Campus (All) }\end{array}$ & 1059.21 & $\begin{array}{c}102,418- \\
253,610\end{array}$ & $3,405-6,401$ & $\$ 170,238-\$ 320,070$ & $\$ 13,320,765$ \\
\hline $\begin{array}{l}\text { UM- } \\
\text { Dearborn } \\
\text { Campus } \\
\end{array}$ & 70.85 & $\begin{array}{l}6,483- \\
14,331\end{array}$ & $242-442$ & $\$ 12,084-\$ 22,120$ & $\$ 165,992$ \\
\hline $\begin{array}{l}\text { UM- } \\
\text { Dearborn } \\
\text { Fairlane } \\
\text { Center }\end{array}$ & 12.29 & $679-1,545$ & $26-48$ & $\$ 1,279-\$ 2,378$ & $\$ 14,037$ \\
\hline \begin{tabular}{|l} 
UM- \\
Dearborn \\
Chancellor's \\
Residence
\end{tabular} & 0.17 & $20-43$ & $0.7-1.3$ & $\$ 37-\$ 67$ & $\$ 429$ \\
\hline $\begin{array}{l}\text { UM-Flint } \\
\text { Campus }\end{array}$ & 31.46 & $\begin{array}{c}1,149- \\
2,942\end{array}$ & $45-90$ & $\$ 2,265-\$ 4,483$ & $\$ 22,462$ \\
\hline $\begin{array}{l}\text { SEAS } \\
\text { Properties }\end{array}$ & & & & & \\
\hline
\end{tabular}




\begin{tabular}{|c|c|c|c|c|c|}
\hline \begin{tabular}{|l} 
Harper \\
Preserve
\end{tabular} & 152.10 & $\begin{array}{c}16,571- \\
60,177\end{array}$ & $536-1,126$ & $\$ 26,808-\$ 56,325$ & $\$ 6,309,741$ \\
\hline $\begin{array}{l}\text { Stinchfield } \\
\text { Woods }\end{array}$ & 312.79 & $\begin{array}{l}58,616- \\
105,912\end{array}$ & $1,914-3,264$ & $\$ 95,700-\$ 163,194$ & $\$ 1,500,394$ \\
\hline $\begin{array}{l}\text { St. Pierre } \\
\text { Wetlands } \\
\text { Preserve }\end{array}$ & 52.84 & $\begin{array}{l}5,852- \\
39,376\end{array}$ & $190-536$ & $\$ 9,519-\$ 26,785$ & $\$ 6,215,242$ \\
\hline $\begin{array}{l}\text { Ringwood } \\
\text { Forest }\end{array}$ & 65.56 & $\begin{array}{c}11,460- \\
42,335\end{array}$ & $380-808$ & $\$ 19,014-\$ 40,393$ & $\$ 4,557,539$ \\
\hline \begin{tabular}{|l|} 
Saginaw \\
Forest
\end{tabular} & 37.37 & $\begin{array}{l}6,068- \\
17,430\end{array}$ & 199-385 & $\$ 9,935-\$ 19,255$ & $\$ 1,440,038$ \\
\hline $\begin{array}{l}\text { Newcomb } \\
\text { Tract }\end{array}$ & 100.16 & $\begin{array}{c}17,629- \\
44,906\end{array}$ & $588-1,100$ & $\$ 29,387-\$ 54,978$ & $\$ 2,919,812$ \\
\hline \multicolumn{6}{|l|}{$\begin{array}{l}\text { MBGNA } \\
\text { Properties }\end{array}$} \\
\hline $\begin{array}{l}\text { Matthaei } \\
\text { Botanical } \\
\text { Gardens }\end{array}$ & 145.86 & $\begin{array}{c}22,198- \\
82,611\end{array}$ & $718-1,536$ & $\$ 35,900-\$ 76,781$ & $\$ 9,269,522$ \\
\hline \begin{tabular}{|l|} 
Nichols \\
Arboretum
\end{tabular} & 58.03 & $\begin{array}{l}9,288- \\
20,292\end{array}$ & $304-547$ & $\$ 15,216-\$ 27,336$ & $\$ 904,454$ \\
\hline $\begin{array}{l}\text { Mud Lake } \\
\text { Bog }\end{array}$ & 100.21 & $\begin{array}{c}15,985- \\
97,969\end{array}$ & $524-1,400$ & $\$ 26,184-\$ 69,981$ & $\$ 14,307,404$ \\
\hline $\begin{array}{l}\text { Horner- } \\
\text { McLaughlin } \\
\text { Woods } \\
\end{array}$ & 40.79 & $\begin{array}{l}7,181- \\
18,926\end{array}$ & $258-487$ & $\$ 12,905-\$ 24,345$ & $\$ 1,006,323$ \\
\hline \multicolumn{6}{|l|}{$\begin{array}{l}\text { UMBS } \\
\text { Properties }\end{array}$} \\
\hline $\begin{array}{l}\text { Biological } \\
\text { Station }\end{array}$ & 4092.75 & $\begin{array}{l}712,594- \\
1,733,850\end{array}$ & $23,279-42,963$ & $\begin{array}{c}\$ 1,163,959- \\
\$ 2,148,146\end{array}$ & $\$ 107,978,127$ \\
\hline
\end{tabular}




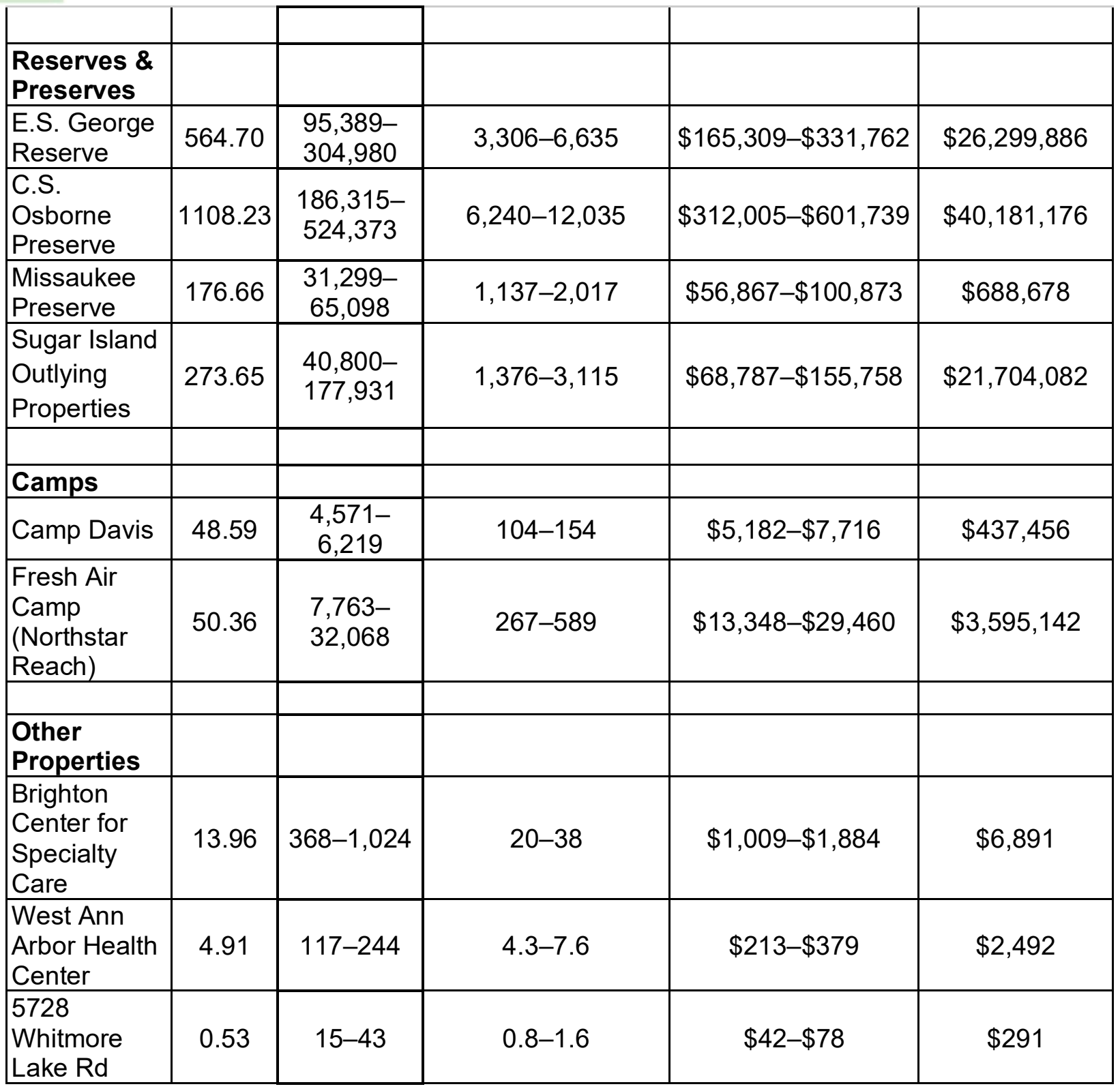




\begin{tabular}{|c|c|c|c|c|c|}
\hline $\begin{array}{l}\text { WVGR } \\
\text { Transmitter }\end{array}$ & 8.51 & $984-1,961$ & $38-66$ & $\$ 1,887-\$ 3,304$ & $\$ 19,260$ \\
\hline $\begin{array}{l}\text { Rackham } \\
\text { Educational } \\
\text { Memorial } \\
\end{array}$ & 1.80 & 83-191 & $3.5-6.3$ & $\$ 174-\$ 316$ & $\$ 1,707$ \\
\hline 86 Eliot St & 0.08 & $3-7$ & $0.1-0.2$ & $\$ 6-\$ 12$ & $\$ 56$ \\
\hline \begin{tabular}{|l|} 
Willow Run \\
Facility \\
\end{tabular} & 54.13 & $\begin{array}{l}7,828- \\
29,123 \\
\end{array}$ & $256-553$ & $\$ 12,821-\$ 27,648$ & $\$ 3,150,469$ \\
\hline \begin{tabular}{|l|} 
Women's \\
Crew Facility \\
\end{tabular} & 1.77 & $224-475$ & $8.2-15$ & $\$ 411-\$ 737$ & $\$ 7,517$ \\
\hline Totals & 8640 & $\begin{array}{c}1,369,950- \\
3,679,991 \\
\end{array}$ & $45,370-86,366$ & $\begin{array}{c}\$ 2,268,493- \\
\$ 4,318,299 \\
\end{array}$ & $\$ 266,027,384$ \\
\hline
\end{tabular}

\section{List of Ecosystem Services}

Table F2. List of ecosystem services for natural lands.

\section{Main service types}

\section{PROVISIONING SERVICES}

1 Food (e.g., fish, game, fruit)

2 Water (e.g., for drinking, irrigation, cooling)

3 Raw Materials (e.g., fiber, timber, fuel wood, fodder, fertilizer)

4 Genetic resources (e.g., for crop-improvement and medicinal purposes)

5 Medicinal resources (e.g., biochemical products, models \& test-organisms)

6 Ornamental resources (e.g., artisan work, decorative plants, pet animals, fashion) REGULATING SERVICES 
7 Air quality regulation (e.g., capturing (fine) dust, chemicals, etc.)

8 Climate regulation (incl. C-sequestration, influence of vegetation on rainfall, etc.)

9 Moderation of extreme events (e.g., storm protection and flood prevention)

10 Regulation of water flows (e.g., natural drainage, irrigation and drought prevention)

11 Waste treatment (especially water purification)

12 Erosion prevention

13 Maintenance of soil fertility (incl. soil formation)

14 Pollination

15 Biological control (e.g., seed dispersal, pest and disease control) HABITAT SERVICES

16 Maintenance of life cycles of migratory species (incl. nursery service)

17 Maintenance of genetic diversity (especially in gene pool protection)

CULTURAL \& AMENITY SERVICES

18 Aesthetic information

19 Opportunities for recreation \& tourism

20 Inspiration for culture, art and design

21 Spiritual experience

22 Information for cognitive development 
Source: Created by de Groot et al. (2010); based on work by Costanza, de Groot, and Farberk (1997), de Groot et al. (2002), MEA (2005), Daily et al. (2009).

\section{Carbon Sequestration Rates}

Table F3. Literature-based carbon sequestration rates for different cover types present on U-M lands.

\begin{tabular}{|c|c|c|}
\hline Habitat type & $\begin{array}{r}\text { Literature-based sequestration rate range } \\
(\mathbf{t C O} \text { e/ha/yr) }\end{array}$ & Reference \\
\hline Forest, Coniferous & 8.43 & Gahagan et al. 2015 \\
\hline Forest, Deciduous & 10.63 & Curtis et al. 2002 \\
\hline Forest, Deciduous & $6.60-11.73$ & Ma et al. 2020 \\
\hline Forest, Mixed & 7.11 & Froelich et al. 2015 \\
\hline Forest, Mixed & $5.46-7.52$ & Niu and Duiker 2006 \\
\hline Forest, Reforestation of \\
Agricultural Land
\end{tabular}




\begin{tabular}{|c|c|c|}
\hline Turfgrass & $3.3-3.67$ & Qian and Follett 2002 \\
\hline Turfgrass & 2.53 & Huh et al. 2008 \\
\hline Turfgrass/Fescue & $1.17-2.86$ & Qian et al. 2010 \\
\hline Wetland & $4.54-15.03$ & \multirow{3}{*}{ Bernal and Mitsch 2012} \\
\hline Wetland & $5.24-10.14$ & \\
\hline Wetland, Constructed & $8.03-9.8$ & \\
\hline Wetland, Constructed & $2.67-24.04$ & de Klein and van der Werf 2014 \\
\hline
\end{tabular}




\section{Appendix G - Details on additional wetland properties}

Two wetland properties in Hamburg Township have recently been placed on the market. These properties are adjacent to St. Pierre Wetland, a property managed by U-M SEAS (Figures G1 and G2). According to the Bioreserve Assessments conducted by the Huron River Watershed Council, these properties are the last intact wetland prairie ecosystems in Hamburg Township that remain unprotected (HRWC 2017). The current owners as well as members of the local community are eager to secure the properties for preservation rather than allow them to enter the market for residential development.

Hooker Road property

The first property, listed for $\$ 1,900,000$, is located on Hooker Road and is part of a larger network of wetlands and lakes, including Mohican Lake and Bass Lake. It is 20.5 hectares (12 hectares of wetlands and 0.2 hectares of forest) (Figure G4). Based on the 8.21 to 15.03 $\mathrm{tCO}_{2} \mathrm{e} / \mathrm{ha} / \mathrm{yr}$ range and the derived land cover area, we estimate the annual biosequestration rate of the Hooker Road property to be 64 to $185 \mathrm{tCO}_{2} \mathrm{e} / \mathrm{yr}$, which would be valued between $\$ 3,200$ and $\$ 9,250$ for annual carbon sequestration value. The estimated carbon storage for the Hooker Road property is 2,000-13,600 t C. Annual ecosystem services for this property is estimated at $\$ 2.2$ million.

\section{Whitewood property}

The second property is 28.5 hectares (16.65 hectares of wetlands and 8.63 hectares of forest) (Figure G3) and is currently listed for sale at $\$ 599,000$. Both sites were assessed by the HRWC and received scores significantly higher than average in terms of ecological integrity.

Biosequestration rates measured in natural, freshwater wetlands vary but have been estimated to range from 8.21 to $15.03 \mathrm{tCO}_{2} \mathrm{e} / \mathrm{ha} / \mathrm{yr}$ (Bernal and Mitsch 2012). Based on this range and the land cover area derived from our LULC classifications and data from the National Wetlands Inventory (Figures G3 and G4), we estimate that the annual biosequestration rate of this property is $142-343 \mathrm{tCO}_{2} \mathrm{e} / \mathrm{yr}$ and would be valued between $\$ 7,100$ and $\$ 17,150$ (based on the current $\$ 50$ social cost of carbon). The estimated carbon storage for the Whitewood property is $4,500-21,700$ t C. Annual ecosystem services for this property is estimated at $\$ 2.9$ million.

It is highly recommended that U-M partner with conservation organizations, land conservancies, and neighboring communities, including the Portage, Base, and Whitewood Owners Association, Livingston Land Conservancy, Huron River Watershed Council, Hamburg Township, Ducks Unlimited, Michigan Nature Association, and the Michigan United Conservation Clubs (MUCC). By actively collaborating with these organizations, U-M would help protect these wetland ecosystems from future development and degradation, ensuring they maintain their ability to sequester and store carbon and perform other essential ecosystem services that benefit the entire Huron River Watershed.

Local residents have expressed great interest in helping maintain these wetland areas, including helping with invasive species removal. In addition to using the properties for educational and research purposes, this would be a great opportunity for U-M students and faculty to participate in community engagement and outreach. Community workshops could be held and informational pamphlets could be created and disseminated to help inform local residents about invasive species, use of fertilizers, and ways to minimize disturbance. Volunteer workdays and invasive species removal days could be organized with students and members of the local 
communities. (See Priority \#2.) Students and volunteers could also help with long-term monitoring of biosequestration, biodiversity, and general wetland health by taking soil cores, water samples, and participating in an annual/bi-annual bioblitz.

For additional maps and data provided to our team, please see the folder entitled "Hamburg_wetlands" in the team Q drive on the Graham server. 

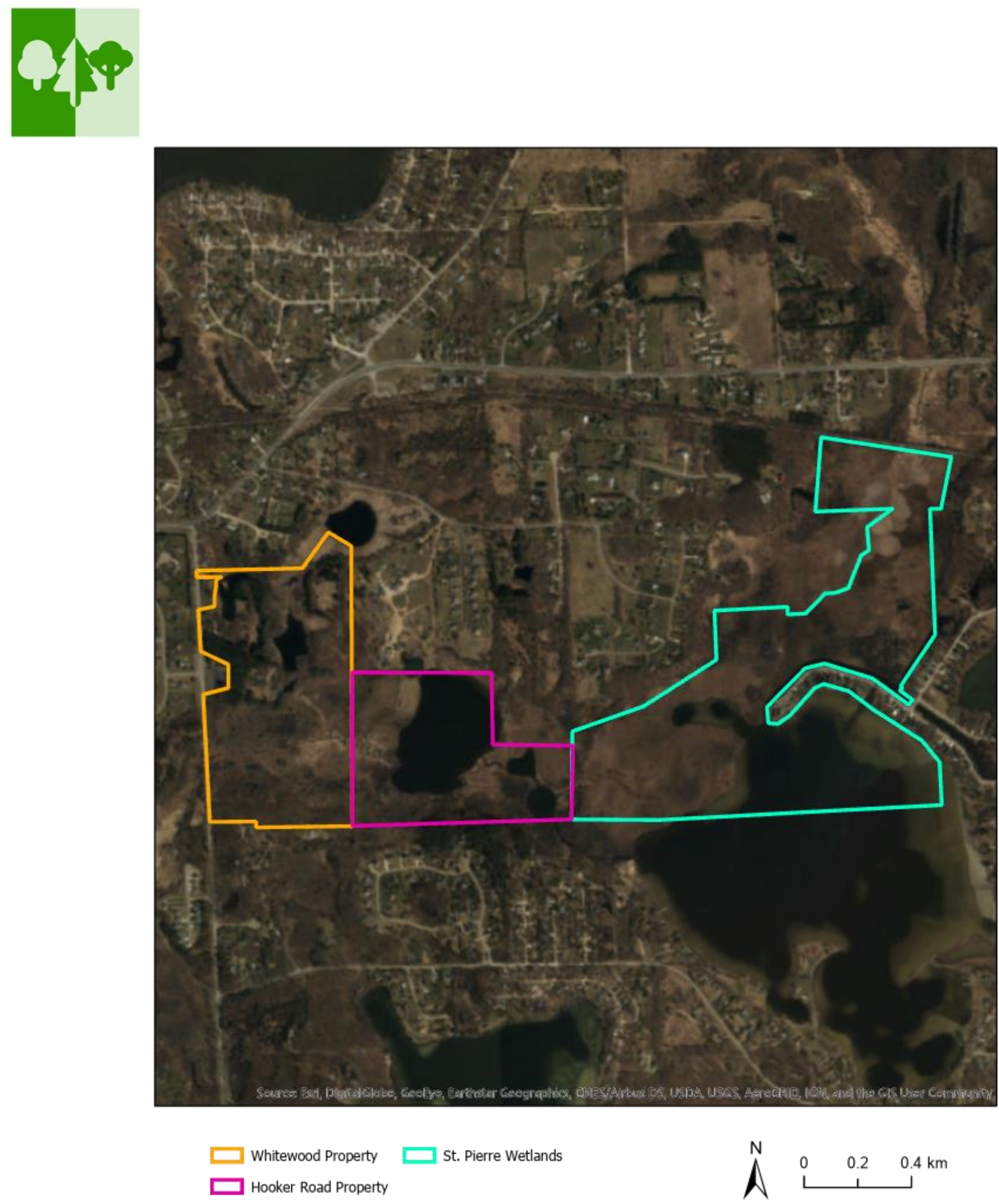

Data Sources: ESRI, Livingston County GIS. Projection/Datum: WGS 1984

Web Mercator Auxiliary Sphere. Map Layout by Lara O'Brien, April 22, 2020.

Figure G1. Whitewood, Hooker Road, and St. Pierre Wetland properties in Hamburg Township, Livingston County, MI (Data sources: ESRI). 

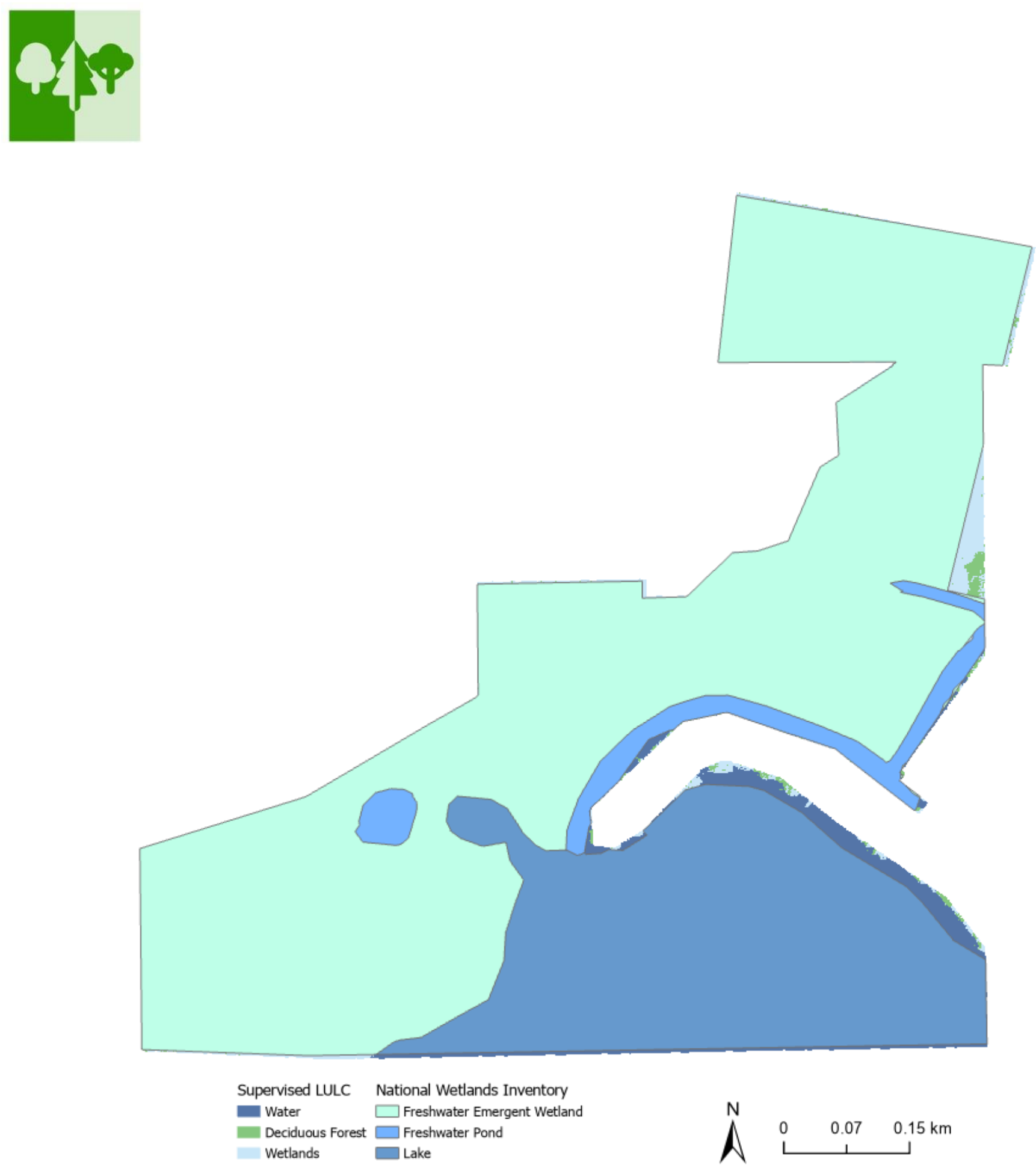

Data Sources: ESRI, NAIP 2018, US FWS National Wetlands Inventory. Projection/Datum: WGS 1984 Web Mercator Auxiliary Sphere. Map Layout by Lara O'Brien, April 22, 2020.

Figure G2. Current LULC for St. Pierre Wetland in Hamburg Township, Livingston County, MI, with data from the National Wetlands Inventory (Data Sources: ESRI, NAIP 2018, US FWS National Wetlands Inventory). 


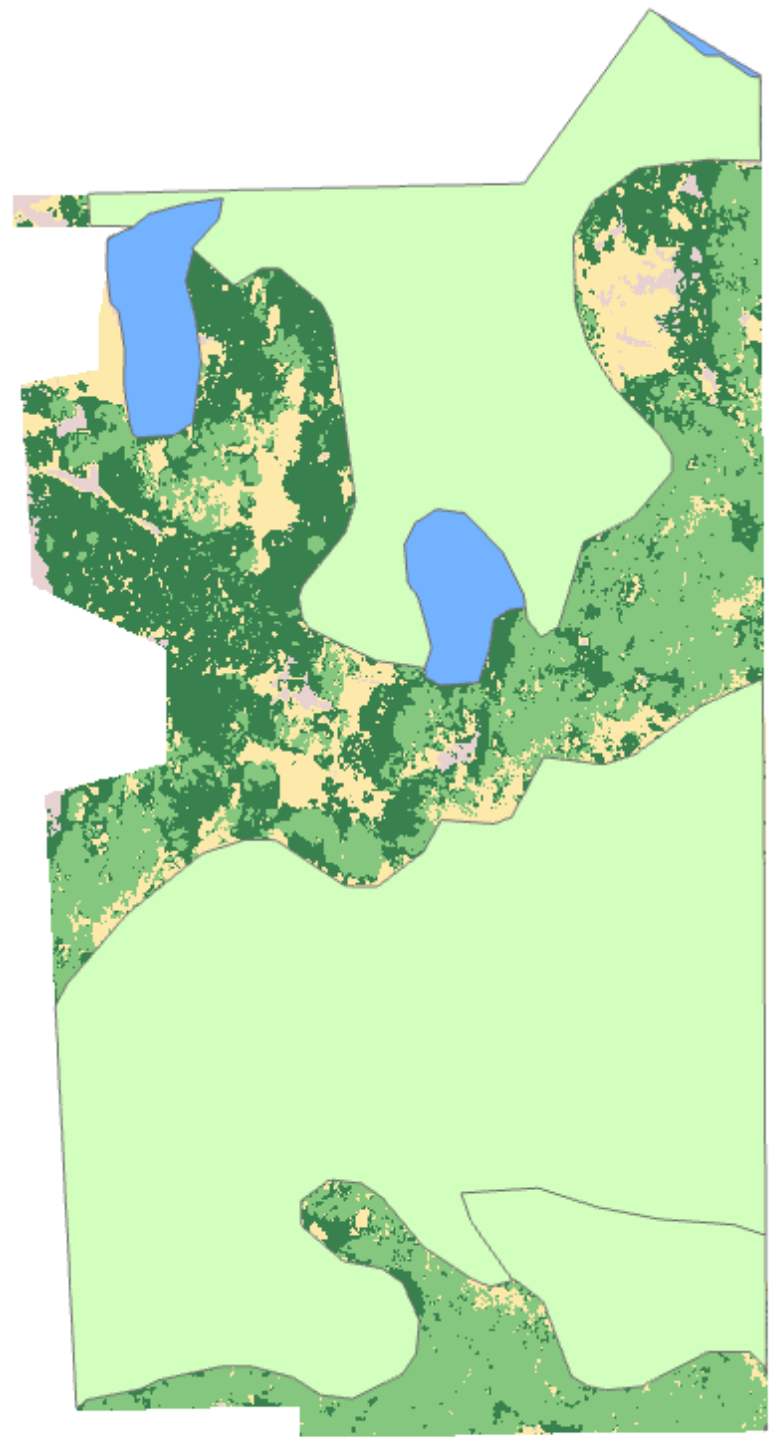

Supervised LULC National Wetlands Inventory

\begin{tabular}{|l|} 
Developed \\
Deciduous Forest \\
Evergreen Forest \\
Herbaceous
\end{tabular}

$\square$ Freshwater Forested/Shrub Wetland

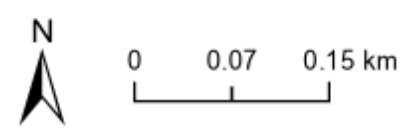

Data Sources: ESRI, NAIP 2018, Livingston County GIS, US FWS National Wetlands Inventory. Projection/Datum: WGS 1984 Web Mercator Auxiliary Sphere. Map Layout by Lara O'Brien, April 22, 2020.

Figure G3. Current LULC for the Whitewood Property Hamburg Township, Livingston County, MI, with data from the National Wetlands Inventory (Data Sources: ESRI, NAIP 2018, US FWS National Wetlands Inventory). 

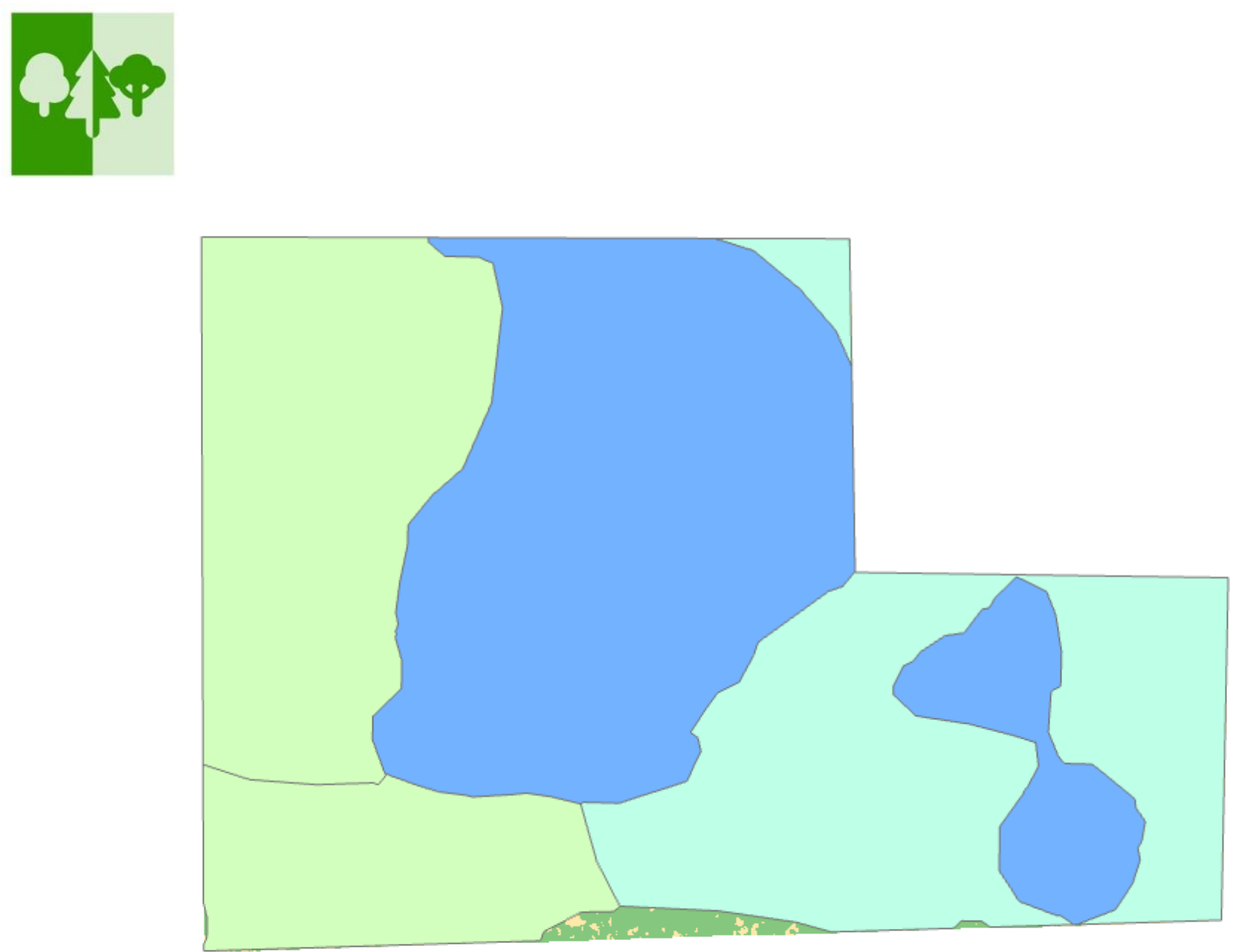

Supervised LULC National Wetlands Inventory

Deciduous Forest $\square$ Freshwater Emergent Wetland

Herbaceous $\square$ Freshwater Forested/Shrub Wetland

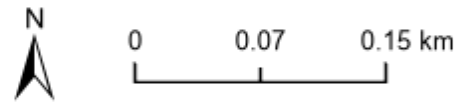

Data Sources: ESRI, NAIP 2018, Livingston County GIS, US FWS National Wetlands Inventory. Projection/Datum: WGS 1984 Web Mercator Auxiliary Sphere. Map Layout by Lara O'Brien, April 22, 2020.

Figure G4. Current LULC for the Hooker Road property Hamburg Township, Livingston County, MI, with data from the National Wetlands Inventory (Data Sources: ESRI, NAIP 2018, US FWS National Wetlands Inventory). 


\section{Appendix $\mathbf{H}-$ Trees on campuses}

$R$ Code (version 3.6.1) for calculating campus tree carbon storage ( $R$ Development Core Team 2019).

The data file was organized with each row as an individual tree, and columns were tree species, tree dbh, tree carbon (calculated), and tree allometric group (Jenkins 2003).

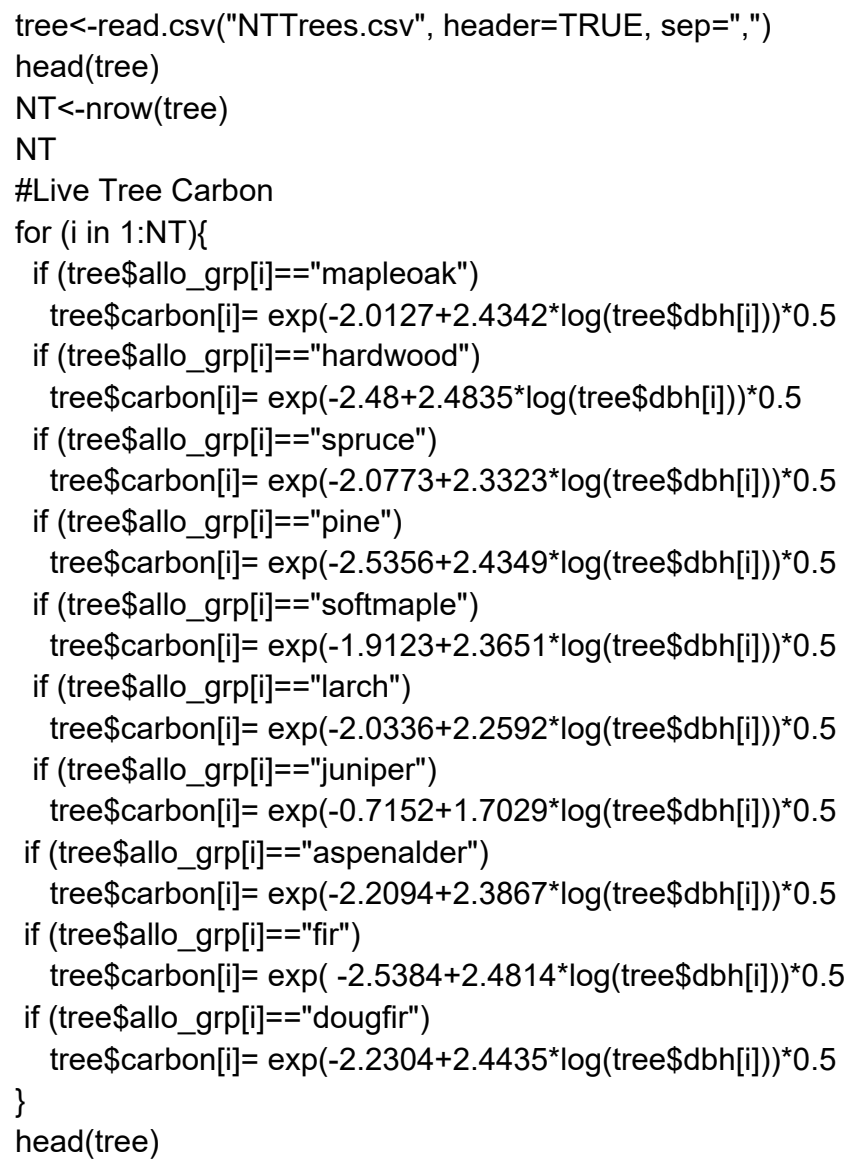

Table H1. Trees on campuses in regard to area covered, number, biodiversity, and carbon storage.

\begin{tabular}{|l|c|c|c|c|}
\hline U-M campus & Area (ha) & $\begin{array}{l}\text { Number of } \\
\text { trees }\end{array}$ & $\begin{array}{l}\text { Biodiversity } \\
\text { (number of } \\
\text { species/varieties) } \\
*\end{array}$ & $\begin{array}{l}\text { Carbon stored in } \\
\text { trees (metric tons) }\end{array}$ \\
\hline Ann Arbor & 1012.03 & 18,871 & 385 & 637.1 \\
\hline Dearborn & 70.45 & 4,529 & 38 & $1,304.3$ \\
\hline Flint & 31.46 & 601 & 41 & 243.4 \\
\hline
\end{tabular}

${ }^{*}$ Ann Arbor tree database included tree varieties where other campuses use species. Therefore, Ann Arbor biodiversity may be artificially high. 


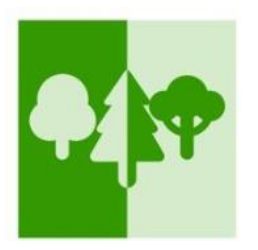

\section{Appendix I - Green infrastructure}

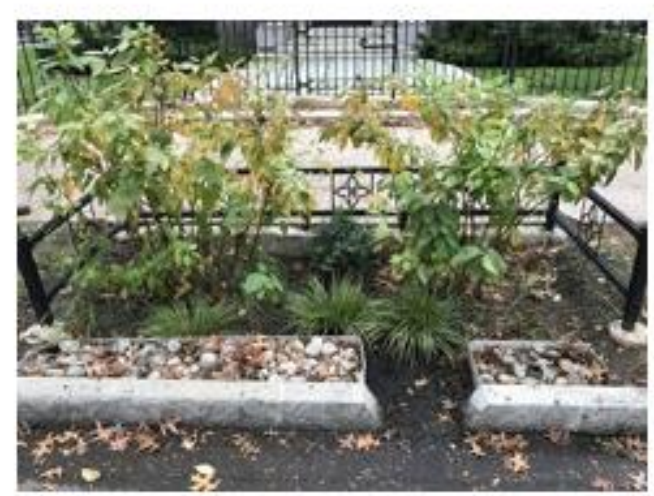

a. Bioswale at Yale Hixon Center for Urban ecology

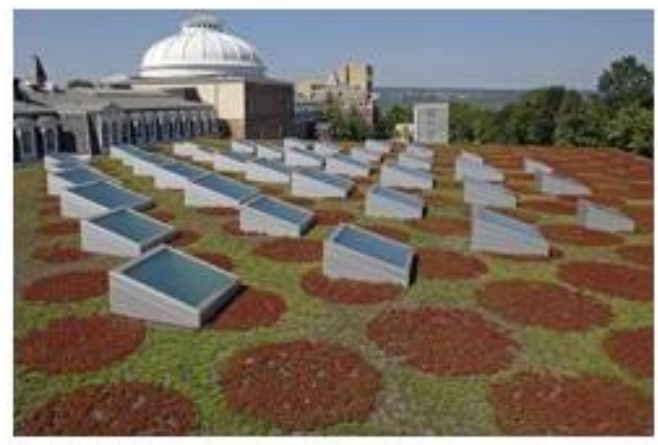

c. Green roof at Comell University Milstein Hall, planted with droughttolerant sedum.

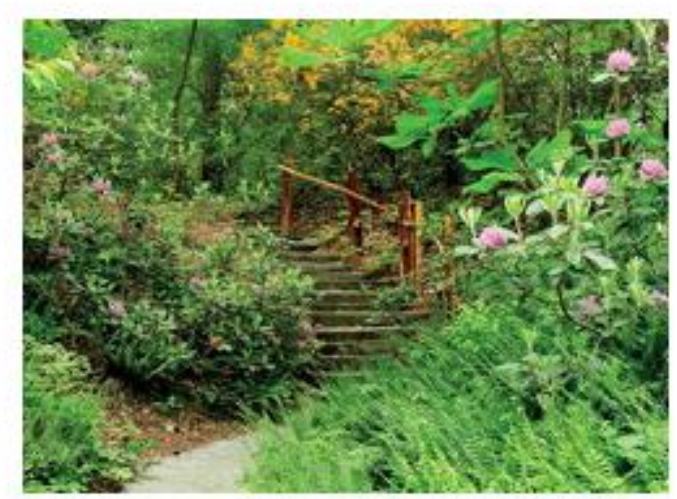

b. Blomquist Garden of Native Plants at Duke University. Photo by Howard Sykes.

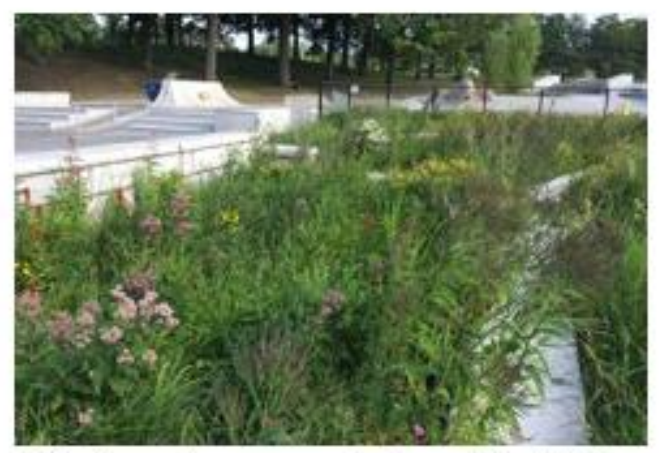

d. Rain garden example from PlantWise, LCC, a restoration company in Ann Arbor

Figure I1. Example pictures of green infrastructure projects showing a a) bioswale, b) native garden, c) green roof, and d) rain garden.

References:

a. "Community Stormwater Partnership Receives National Environmental Award." n.d. Accessed April 26, 2020. https://environment.yale.edu/news/article/community-greeninfrastructure-initiative-earns-national-environmental-award-/.

b. "Blomquist Garden | Duke Gardens." n.d. Accessed April 26, 2020. https://gardens.duke.edu/about/blomquist-garden.

c. "Milstein Hall Earns LEED Gold Certification | Cornell Chronicle." n.d. Accessed April 26, 2020. https://news.cornell.edu/stories/2012/08/milstein-hall-awarded-leed-goldcertification.

d. "Rain Gardens | Plantwise." n.d. Accessed April 26, 2020. http://www.plantwiserestoration.com/rain-gardens/. 


\section{Cost-Benefit Tools and Resources}

\section{All green infrastructure types including bioswales:}

EPA cost-benefit tools to help decision makers create and improve community infrastructure and stormwater management.

"Green Infrastructure Cost-Benefit Resources." EPA. Environmental Protection Agency, September 26, 2017.

https://www.epa.gov/green-infrastructure/green-infrastructure-cost-benefit-resources.

EPA green infrastructure modeling toolkit to help decision makers implement stormwater management practices.

"Green Infrastructure Modeling Toolkit." EPA. Environmental Protection Agency, December

6, 2019. https://www.epa.gov/water-research/green-infrastructure-modeling-toolkit.

Toolkit developed by the Center for Neighborhood Technology (CNT) allows site designers to quickly compare the performance, costs, and benefits of green infrastructure practices to conventional stormwater practices.

"National Stormwater Management Calculator." Green Values Stormwater Toolbox.

Accessed April 27, 2020. http://greenvalues.cnt.org/national/calculator.php.

Quick reference guide by the Center for Neighborhood Technology that compares construction, maintenance costs and component life spans between green and conventional stormwater management.

"National Stormwater Management Calculator." Green Values National Stormwater

Management Calculator. Accessed April 27, 2020.

https://greenvalues.cnt.org/national/cost detail.php.

Green Infrastructure Toolkit was developed in collaboration with leading cities to help them identify and deploy green infrastructure approaches in their communities.

"Green Infrastructure Toolkit: Introduction-Georgetown Climate Center."

georgetownclimatecenter.org. Accessed April 27, 2020.

https://www.georgetownclimate.org/adaptation/toolkits/green-infrastructure-

toolkit/introduction.html.

\section{Rain gardens:}

Rain garden cost calculator developed by the University of Connecticut.

"Cost Calculator." UConn Rain Gardens "How To" Guide. Accessed April 27, 2020. https://nemo.uconn.edu/raingardens/calculator.htm.

EPA tools and resources about rain gardens, including community outreach and communication. 
"Soak Up the Rain: Rain Gardens." EPA. Environmental Protection Agency, April 10, 2020. https://www.epa.gov/soakuptherain/soak-rain-rain-gardens.

Rain garden calculator developed by the Rain Garden Alliance.

"What Size Garden Do I Need?" Three Rivers Rain Garden Alliance. Accessed April 27, 2020. http://raingardenalliance.org/right/calculator.

\section{Native garden/urban meadow:}

Tools and resources on transforming lawn to meadow from ConservationTools.org, administered by the Pennsylvania Land Trust Association.

"From Lawn to Meadow." ConservationTools. Accessed April 27, 2020.

https://conservationtools.org/guides/151-from-lawn-to-meadow.

Guide to Meadows and Prairies: Wildlife-Friendly Alternatives to Lawn from Penn State. Brittingham, Margaret C. "Meadows and Prairies: Wildlife-Friendly Alternatives to Lawn." Penn State Extension, April 19, 2020. https://extension.psu.edu/meadows-and-prairieswildlife-friendly-alternatives-to-lawn.

\section{Green roofs:}

Green roof energy calculator to calculate energy savings of a green roof compared to conventional from the Arizona State University Urban Climate Research Center.

"Green Roof Energy Calculator." Urban Climate Research Center. Accessed April 27, 2020. https://sustainability.asu.edu/urban-climate/green-roof-calculator/.

EPA tools and resources for green roofs, including installation and maintenance costs. "Using Green Roofs to Reduce Heat Islands." EPA. Environmental Protection Agency, June 11, 2019. https://www.epa.gov/heat-islands/using-green-roofs-reduce-heat-islands.

\section{Examples of green infrastructure from other institutions:}

Yale University

Sustainability Tour for all aspects of sustainability actions:

"Sustainability Tour | Yale Sustainability." n.d. Accessed April 27, 2020.

https://sustainability.yale.edu/take-action/sustainability-tour.

Green spaces at Yale, including examples of green infrastructures:

"Green Spaces | Yale Sustainability." n.d. Accessed April 27, 2020.

https://sustainability.yale.edu/take-action/sustainability-tour/green-spaces.

Urban meadows:

"Yale Creates Urban Meadows | Yale Sustainability." n.d. Accessed April 27, 2020.

https://sustainability.yale.edu/news/yale-creates-urban-meadows.

Map of the different urban meadows:

"Urban Meadows Map | Yale Sustainability." n.d. Accessed April 27, 2020.

https://sustainability.yale.edu/resources/urban-meadows-map.

Stormwater management plan including bioswale and rain gardens construction: 
"Stormwater Management Plan-2018 | Yale Sustainability." n.d. Accessed April 27, 2020. https://sustainability.yale.edu/resources/stormwater-management-plan-2018.

Article about rain garden project involving students and active learning:

"Planting Green Infrastructure Outside of the Classroom... Literally." n.d. Accessed April 27, 2020. https://environment.yale.edu/news/article/planting-green-infrastructure-outsidethe-classroom-literally/.

Bioswale project cooperating with the city:

"Community Stormwater Partnership Receives National Environmental Award." n.d.

Accessed April 27, 2020. https://environment.yale.edu/news/article/community-greeninfrastructure-initiative-earns-national-environmental-award-l.

Cornell University

Sustainable Landscapes Trail highlighting sustainable sites on campus:

"Sustainable Landscapes Trail | Sustainable Campus." n.d. Accessed April 27, 2020. https://sustainablecampus.cornell.edu/campus-initiatives/land-water/sustainablelandscapes-trail.

Green roof and roof stormwater fed rain garden: "Fernow Green Roof and Rain Garden | Sustainable Campus." n.d. Accessed April 27, 2020. https://sustainablecampus.cornell.edu/campus-initiatives/land-water/sustainablelandscapes-trail/fernow-green-roof-and-rain-garden.

24,000-square-foot green roof on a LEED Gold certification building: "Milstein Hall Earns LEED Gold Certification | Cornell Chronicle." n.d. Accessed April 27, 2020. https://news.cornell.edu/stories/2012/08/milstein-hall-awarded-leed-gold-certification.

Library top human occupiable green roof:

"Mann Library Green Roof | Sustainable Campus." n.d. Accessed April 27, 2020.

https://sustainablecampus.cornell.edu/campus-initiatives/land-water/sustainablelandscapes-trail/mann-library-green-roof.

Native lawns with short and slow growing grass species:

"Botanic Gardens Native Lawn | Sustainable Campus." n.d. Accessed April 27, 2020. https://sustainablecampus.cornell.edu/campus-initiatives/land-water/sustainablelandscapes-trail/botanic-gardens-native-lawn.

Green infrastructure and bioswale:

"Green Infrastructure and Stormwater Management | New York State Water Resources Institute." n.d. Accessed April 27, 2020. https://wri.cals.cornell.edu/hudson-riverestuary/watershed-management/green-infrastructure-and-stormwater-management/.

Harvard University

List of green roofed buildings:

"Nature \& Ecosystems | Sustainability at Harvard." n.d. Accessed April 27, 2020. https://green.harvard.edu/topics/nature-ecosystems.

Photo of a green roof at Harvard Business School Shad Hall:

"Harvard University Business School Shad Hall—Greenroofs.Com." n.d. Accessed April 27, 2020. https://www.greenroofs.com/projects/harvard-university-business-school-shad-hall/. 
Duke University

Blomquist Garden of Native Plants:

"Blomquist Garden | Duke Gardens." n.d. Accessed April 27, 2020.

https://gardens.duke.edu/about/blomquist-garden. 


\section{Appendix $\mathrm{J}$ - Wetland preservation, tree protection, and turfgrass conversion considerations for the Ann Arbor campus}

\section{Wetland preservation}

Wetlands in the Midwest are one of the land cover types with the highest biosequestration rates. In addition to wetlands in "natural areas" discussed in recommendation \#1 and \#2, there are hectares of wetlands on the Ann Arbor campus that require preservation, most notably around the East Medical Campus. In addition, soil and drainage patterns determined by Andropogon Associates, Ltd. provide useful information on priority areas for consideration of stormwater and wastewater treatment.

\section{Stormwater management}

Sustainability officers of Ann Arbor have noted flooding of Pittsfield Village and parts of the Fourth Ward. We should try to work with the City of Ann Arbor in regard to areas needing stormwater management for the introduction of potential green infrastructure.

\section{Trees}

Facilities and Operations on the Ann Arbor campus have produced requirements for tree preservation, protection, rankings, relocation, and removals and replacements on that campus.

\section{Turfgrass conversion to low or no mow}

Areas of Ann Arbor campus that could be priority for conversion from turfgrass to low or no mow are provided in Table $\mathrm{J} 1$. This table was produced by current SEAS Facilities and Operations Manager, Sucila Fernandes, who previously served as a landscape planner in U-M's Architecture, Engineering, and Construction Unit.

Table J1. Identification of Ann Arbor campus areas for potential areas of conversion from turfgrass to low or no mow.

\begin{tabular}{|c|c|}
\hline $\begin{array}{r}\text { Ann Arbor Campus } \\
\text { Area }\end{array}$ & Recommendation \\
\hline Northwood & $\begin{array}{l}\text { Review U-M North Campus Master plan and follow most areas of the Open Space Framework "Huron } \\
\text { Valley Woodland Areas" and expand out from there. In addition, key areas to improve protection of mature } \\
\text { trees with higher values of Carbon Sequestration include Northwood I \& Northwood II. Many of the areas } \\
\text { mowed in between these trees should be left alone to allow this area to naturally grow more of these } \\
\text { species of trees with some maintenance of invasive. }\end{array}$ \\
\hline NCRB & $\begin{array}{l}\text { All areas around NCRB expect those closest to the entrance could be no mow, particularly the area north } \\
\text { of the building as it approaches Plymouth Road }\end{array}$ \\
\hline Baits I + II & $\begin{array}{l}\text { All steep areas around these buildings should be converted to no mow and stabilized with noninvasive } \\
\text { plant species. The back drive to Bursley just east of Baits, should expand to no mow areas. }\end{array}$ \\
\hline Music School & $\begin{array}{l}\text { The area east and SW of the music school pond should increase no mow areas but leave some strategic } \\
\text { areas for people to enjoy the beauty of these majestic trees. }\end{array}$ \\
\hline Bonisteel & $\begin{array}{l}\text { Median should be planted with low mow grass with strategic native plant swales that can help with carbon } \\
\text { sequestration }\end{array}$ \\
\hline Bonisteel East & $\begin{array}{l}\text { Area just to the east of Bonisteel as it approaches North Campus along the west side of Art \& Architecture } \\
\text { at one time was a potential site for detention and might make sense for it to be a wetland or reduced to } \\
\text { low or no mow area. }\end{array}$ \\
\hline
\end{tabular}




\begin{tabular}{|c|c|}
\hline $\begin{array}{r}\text { Behind Bentley \& Ford } \\
\text { Library }\end{array}$ & Could reduce lawn for these areas. \\
\hline Power Center & $\begin{array}{l}\text { This area is currently large trees and lawn. Low mow plants should be filtered in to replace the current } \\
\text { seed mix there. This area is used for recreation during campus events }\end{array}$ \\
\hline Dental, LSI \& USB & $\begin{array}{l}\text { There are areas around these buildings where the slopes are steep and difficult to mow. These areas } \\
\text { should get converted to low maintenance areas to avoid mowing. }\end{array}$ \\
\hline Chemistry \& Kraus & $\begin{array}{l}\text { Areas around these buildings are behind low walls and makes it difficult to get lawnmowers up to them. } \\
\text { These areas should be converted to no mow. They are infrequently used by recreation and also difficult to } \\
\text { grow grass due to shade. }\end{array}$ \\
\hline Triangle Lot & $\begin{array}{l}\text { Where Geddes, North } U \text { and Washtenaw come together is a triangle lot that rarely has anyone taking } \\
\text { advantage of the lawn. This would be a prime opportunity for native plants or no lawn. }\end{array}$ \\
\hline CCRB & West side of the CCRB is another area that could use no mow or more native plants. \\
\hline Palmer Fields & $\begin{array}{l}\text { South side of Palmer Fields just south of the tennis courts has a steep hill with limited activity. This area } \\
\text { should be converted to low mow grass or converted to mulch or native plants. This is a prime area for } \\
\text { education about no mow/low mow treatments. }\end{array}$ \\
\hline Mojo & $\begin{array}{l}\text { The south and east side of this residence hall has areas that are difficult to mow due to the slop and } \\
\text { access. These areas should get converted to no mow. These could be great rainwater gardens, as I } \\
\text { believe storm drainage already exists there. }\end{array}$ \\
\hline SPHI & $\begin{array}{l}\text { The Observatory side of SPHI should be a good place to plant more trees. This area could be an } \\
\text { enhanced space for educating people about No Mow and the health benefits. }\end{array}$ \\
\hline Simpson Institute & $\begin{array}{l}\text { This area south of the Simpson Institute should get protected as it doesn't have any utilities running } \\
\text { through it and therefore limits damage to these well-established trees. This is a small lot of high-quality } \\
\text { trees on the Medical Campus. Areas to the north should also be converted to the low or no mow } \\
\text { landscape plan }\end{array}$ \\
\hline Detroit Observatory & $\begin{array}{l}\text { Areas around this building are very difficult to mow and have some unique trees. This is an interesting } \\
\text { area where mulch works well to get rid of lawn. }\end{array}$ \\
\hline Fuller Road & $\begin{array}{l}\text { Much of the slope along Fuller road from Zina Pitcher to East Medical Center drive on the east could be } \\
\text { converted to low mow. A creative way to incorporate natives and possibly wetland species would make } \\
\text { sense here as it flows towards the River. }\end{array}$ \\
\hline Tennis Center & $\begin{array}{l}\text { Much of the area east of the courts are steep slopes but also were at one time prairie grasses. If restored } \\
\text { back to this no mow condition this could be an area for improved carbon sequestration. }\end{array}$ \\
\hline Soccer & Areas to the east of the soccer fields appear to be areas that could be converted to no mow. \\
\hline
\end{tabular}


Appendix K - Biosequestration rates and their timelines of land cover types and proposed projects with costs and descriptions of tradeoffs for land conversion

Comments or requests from the PCCN are listed in bold with responses from the biosequestration team below.

1) Trajectories for implementation of the proposed interventions and when estimated max. sequestration levels will be fully realized.

See the response to the next comment.

2) Creation of an easy-to-navigate table which outlines cost per ton carbon sequestration for each proposed intervention.

In the following section, we have created a table that lists the annual biosequestration rate range as well as the biosequestration value in terms of a $\$ 50$ social cost of carbon and the ecosystems services value of each proposed intervention. Also, in this table we have listed the one-time project costs as well as the per year project staff costs and per year materials and equipment costs. We have also included estimates of the trajectories of biosequestration rates. Providing funds for paid staff positions prioritizes a Michigan land ethic and is more equitable. There is currently one Facilities and Operations manager for SEAS properties and the Dana Building. However, SEAS properties encompass 721 hectares, and these properties have great potential to help U-M "demonstrate the University's commitment to land preservation, sustainable stewardship, and carbon neutrality" (DeYoung et al. 2020;

https://deepblue.lib.umich.edu/handle/2027.42/154880). The number of land managers for properties like SEAS, MBGNA, and UMBS should be increased in the context of the university's commitment to sustainability goals. 
Table K1. Details on projects proposed including priority, area preserved, estimated biosequestration rate, biosequestration value, ecosystems services value, and estimated costs of each proposed project including one-time costs and annual costs in staff, and non-staff materials and equipment.

\begin{tabular}{|c|c|c|c|c|c|c|c|c|c|c|}
\hline $\begin{array}{l}\text { Priority \# of } \\
\text { intervention }\end{array}$ & Proposed project & $\begin{array}{l}\text { Area } \\
\text { preserved } \\
\text { or altered } \\
\text { (ha) }\end{array}$ & $\begin{array}{l}\text { Bio seq low } \\
\left(\mathrm{tCO}_{2} \mathrm{e} / \mathrm{yr}\right)\end{array}$ & $\begin{array}{l}\text { Bio seq high } \\
\left(\mathrm{tCO}_{2} \mathrm{e} / \mathrm{yr}\right)\end{array}$ & $\begin{array}{l}\text { Annual bio } \\
\text { seq value } \\
\operatorname{low}^{*}(\$)\end{array}$ & $\begin{array}{l}\text { Annual bio } \\
\text { seq value } \\
\text { high* }(\$)\end{array}$ & $\begin{array}{l}\text { Ecosystems } \\
\text { services } \\
\text { value }(\$) \\
\end{array}$ & $\begin{array}{l}\text { One-time } \\
\text { project costs } \\
\text { in purchase } \\
\text { of land or } \\
\text { materials or } \\
\text { labor }(\$)\end{array}$ & $\begin{array}{l}\text { Annual } \\
\text { project } \\
\text { costs in } \\
\text { staff }(\$)\end{array}$ & $\begin{array}{l}\text { Annual project } \\
\text { costs in non- } \\
\text { staff materials/ } \\
\text { equipment }(\$)\end{array}$ \\
\hline $1 \mathrm{AB}$ & $\begin{array}{l}\text { Preserve natural } \\
\text { areas }\end{array}$ & 7,381 & 41,320 & 78,698 & $2,066,000$ & $3,934,900$ & $249,361,884$ & 0 & 215,000 & 551,361 \\
\hline $1 \mathrm{C}$ & $\begin{array}{l}\text { Purchase } \\
\text { wetlands }\end{array}$ & 49 & 206 & 528 & 10,300 & 26,400 & $5,100,000$ & $2,500,000$ & 35,000 & 3,660 \\
\hline $2 \mathrm{~A}$ & $\begin{array}{l}\text { Convert ag land } \\
\text { to wetland } \\
\text { Restore and } \\
\text { enhance }\end{array}$ & 36 & - & 257 & - & 12,850 & $4,198,608$ & $2,300,000$ & 15,000 & 20,568 \\
\hline $2 \mathrm{BC}$ & wetlands & 51.5 & - & 252 & - & 12,600 & $4,438,805^{b}$ & 50,000 & 103,500 & 16,347 \\
\hline 2BC & $\begin{array}{l}\text { Restore and } \\
\text { enhance forests }\end{array}$ & 5 & - & 46 & - & 2,300 & 19,295 & 227,000 & 11,500 & 10,000 \\
\hline $3 A$ & $\begin{array}{l}\text { Planting trees on } \\
\text { campus }\end{array}$ & 138 & 753 & 1,618 & 37,650 & 80,900 & 532,474 & $2,240,000$ & $140,000^{c}$ & $140,000^{c}$ \\
\hline $3 B$ & $\begin{array}{l}\text { Turfgrass } \\
\text { conversion }\end{array}$ & 313.5 & - & 24 & - & $1,200^{\mathrm{a}}$ & 535,458 & 550,000 & $0^{d}$ & $0^{d}$ \\
\hline $3 C$ & $\begin{array}{l}\text { Green } \\
\text { infrastructure }\end{array}$ & 30 & 37.2 & 148 & 1,860 & 7,400 & 153,720 & 322,917 & 1,211 & 1,211 \\
\hline
\end{tabular}

*Based on $\$ 50$ social cost of carbon.

aalue here is not due to biosequestration, but due to reductions in $\mathrm{CO}_{2}$ due to reduced mowing, fertilization, and watering.

VValue of estimated increase in ecosystems services value as a result of the project.

'Estimated per year maintenance cost per tree of $\$ 10$ split between staff costs and materials/equipment costs

${ }^{\mathrm{d}}$ Costs are reduced compared to status quo, so $\$ 0$ reflects this fact. 
Mitsch et al. (2013) estimated 31 years for temperate constructed or natural wetlands to go from being a net radiative force to a net radiative sink. Meaning, temperate wetlands become a greenhouse gas sink even after accounting for the greater global warming potential of methane relative to $\mathrm{CO}_{2}$.

Table K2. Timeline of biosequestration rate ranges estimated for constructed temperate wetlands. The reference citing these ranges were included with the location of the constructed wetland in parentheses.

\begin{tabular}{rrl}
$\begin{array}{l}\text { Years after } \\
\text { construction }\end{array}$ & $\begin{array}{l}\text { Biosequestration range } \\
\left(\mathrm{tCO}_{2} \mathrm{e} / \mathrm{ha} / \mathrm{yr}\right)\end{array}$ \\
\hline $0-5$ & 9.17 & Badiou et al. 2011 (Canada) \\
$4-6$ & $2.67-24.04$ & de Klein and van der Werf 2014 (Netherlands) \\
10 & $6.64-7.08$ & Mitsch et al. 2013 (Ohio) \\
12 & $3.67-6.42$ & Reddy et al. 2016 (North Carolina, marsh and pond) \\
15 & $8.03-9.79$ & Mitsch et al. 2013 (Ohio) \\
33 & 9.9 & Badiou et al. 2011(Canada) \\
\hline
\end{tabular}

${ }^{a}$ These constructed wetlands in Ohio are located at the Ohio State University and were used extensively for wetland research from 1991 to 2012.

Table K3. Mean biosequestration rates for natural wetlands in Ohio and the references citing these rates. The type of natural wetland is indicated in parentheses after location.

\begin{tabular}{lrl}
\hline Location & $\begin{array}{l}\text { Biosequestration mean } \\
\left(\mathrm{tCO}_{2} \mathrm{e} / \mathrm{ha} / \mathrm{yr}\right)\end{array}$ & \multicolumn{1}{l}{ Reference } \\
\hline $\begin{array}{l}\text { Ohio } \\
\text { Ohio } \\
\text { (shrub depressional wetland) }\end{array}$ & 1.43 & Mitsch et al. 2013 \\
$\begin{array}{l}\text { Ohio } \\
\text { (forested depressional wetland) }\end{array}$ & 7.41 & Bernal and Mitsch 2012 \\
$\begin{array}{l}\text { Ohio } \\
\text { (marsh depressional wetland) }\end{array}$ & 17.34 & Bernal and Mitsch 2012 \\
$\begin{array}{l}\text { Ohio } \\
\text { (floating bed riverine wetland) }\end{array}$ & 7.70 & Bernal and Mitsch 2012 \\
Ohio (marsh riverine wetland) & 5.87 & Bernal and Mitsch 2012 \\
Ohio (mudflat riverine wetland) & 3.85 & Bernal and Mitsch 2012 \\
\hline
\end{tabular}


Table K4. Timeline of mean biosequestration rates and biosequestration ranges for temperate forests and the references citing these rates and ranges.

\begin{tabular}{lrrl}
\hline $\begin{array}{l}\text { Age }(\mathrm{Age} \\
\text { class in yrs })\end{array}$ & $\begin{array}{l}\text { Biosequestration mean } \\
\left(\mathrm{tCO}_{2} \mathrm{e} / \mathrm{ha} / \mathrm{yr}\right)\end{array}$ & $\begin{array}{l}\text { Biosequestration range } \\
\left(\mathrm{tCO}_{2} \mathrm{e} / \mathrm{ha} / \mathrm{yr}\right)\end{array}$ & Reference \\
\hline $0-10$ & 6.967 & $-45.69-25.74$ & Pregitzer and Euskirchen 2004; Euskirchen et al. 2002 \\
$11-30$ & 16.5 & $-3.85-28.31$ & Pregitzer and Euskirchen 2004; Euskirchen et al. 2002 \\
$31-70$ & 8.8 & $-4.51-30.87$ & Pregitzer and Euskirchen 2004; Euskirchen et al. 2002 \\
$71-120$ & 6.967 & $-4.51-18.0$ & Pregitzer and Euskirchen 2004; Euskirchen et al. 2002 \\
$120-200$ & 6.23 & $-3.23-16.10$ & Pregitzer and Euskirchen 2004; Euskirchen et al. 2002 \\
\hline
\end{tabular}

Table K5. Timeline of biosequestration rates by ecosystem type of natural forest and the references citing these rates.

\begin{tabular}{|c|c|c|c|}
\hline $\begin{array}{l}\text { Age (Age } \\
\text { class in yrs) }\end{array}$ & $\begin{array}{l}\text { Biosequestration range } \\
\left(\mathrm{tCO}_{2} \mathrm{e} / \mathrm{ha} / \mathrm{yr}\right)\end{array}$ & Ecosystem type & Reference \\
\hline $30-97$ & $-2.2-31.9$ & $\begin{array}{l}\text { Broadleaf forests, Fagus sylvatica, } \\
\text { Quercus - Acer }\end{array}$ & Law et al. 2002 \\
\hline $40-45$ & $2.57-7.7$ & Betula - Quercus & Yamamoto et al. 1999; Saigusa et al. 2002 \\
\hline $50-55$ & $10.63-16.13$ & Northern hardwoods & Whittaker et al. 1974 \\
\hline $60-90$ & $6.6-11.73$ & $\begin{array}{l}\text { Acer, Populus, Quercus-Acer (Eastern } \\
\text { North America, including UMBS) }\end{array}$ & Curtis et al. 2002 \\
\hline $60-90$ & $1.1-18.7$ & $\begin{array}{l}\text { Evergreen - deciduous forests; } \\
\text { Pseudotsuga menziesii - Fagus } \\
\text { sylvatica }\end{array}$ & Law et al. 2002 \\
\hline $90-93$ & $2.93-9.9$ & Acer-Populus & Lee et al. 1999; Baldocchi et al. 2001 \\
\hline $91-92$ & $2.93-7.7$ & Populus & Schmid et al. 2000 \\
\hline
\end{tabular}


Table K6. Timeline of biosequestration range for different types of green infrastructure at different locations and the references citing these rates.

\begin{tabular}{|c|c|c|c|c|c|}
\hline Location & Infrastructure & Type/comments & Age/time (yr) & $\begin{array}{l}\text { Biosequestration range } \\
\left(\mathrm{tCO}_{2} \mathrm{e} / \mathrm{ha} / \mathrm{yr}\right)\end{array}$ & Reference \\
\hline Columbia, MD & Green roof & $\begin{array}{l}\text { Above ground extensive GR } \\
\text { (Sedum spp. etc.) } \\
\text { Above ground extensive GR }\end{array}$ & 1.00 & 2.68 & Getter et al. 2009 \\
\hline East Lansing, MI & Green roof & $\begin{array}{l}\text { (Sedum spp. etc.) } \\
\text { Above ground extensive GR }\end{array}$ & 1.25 & 2.85 & Getter et al. 2009 \\
\hline East Lansing, MI & Green roof & $\begin{array}{l}\text { (Sedum spp. etc.) } \\
\text { Above ground extensive GR }\end{array}$ & 1.25 & 3.73 & Getter et al. 2009 \\
\hline East Lansing, MI & Green roof & $\begin{array}{l}\text { (Sedum spp. etc.) } \\
\text { Above ground extensive GR }\end{array}$ & 2.33 & 2.34 & Getter et al. 2009 \\
\hline East Lansing, MI & Green roof & $\begin{array}{l}\text { (Sedum spp. etc.) } \\
\text { Above ground extensive GR }\end{array}$ & 3.25 & 1.62 & Getter et al. 2009 \\
\hline East Lansing, MI & Green roof & $\begin{array}{l}\text { (Sedum spp. etc.) } \\
\text { Above ground extensive GR }\end{array}$ & 3.25 & 1.79 & Getter et al. 2009 \\
\hline East Lansing, MI & Green roof & $\begin{array}{l}\text { (Sedum spp. etc.) } \\
\text { Above ground extensive GR }\end{array}$ & 3.25 & 2.28 & Getter et al. 2009 \\
\hline Dearborn, MI & Green roof & $\begin{array}{l}\text { (Sedum spp. etc.) } \\
\text { Above ground extensive GR }\end{array}$ & 4.00 & 1.80 & Getter et al. 2009 \\
\hline Edgewater, MD & Green roof & $\begin{array}{l}\text { (Sedum spp. etc.) } \\
\text { Above ground extensive GR }\end{array}$ & 4.00 & 2.53 & Getter et al. 2009 \\
\hline East Lansing, MI & Green roof & $\begin{array}{l}\text { (Sedum spp. etc.) } \\
\text { Above ground extensive GR }\end{array}$ & 4.33 & 1.90 & Getter et al. 2009 \\
\hline Jessup, MD & $\begin{array}{l}\text { Green roof } \\
\text { Green roof w/typical }\end{array}$ & (Sedum spp. etc.) & 4.42 & 1.57 & Getter et al. 2009 \\
\hline $\mathrm{OH}$ & $\begin{array}{l}\text { substrate }(10.5 \mathrm{~cm}) \\
\text { Green roof w/typical }\end{array}$ & Sedum & $2-3 \mathrm{yr}$ & 19.00 & Whittinghill et al. 2014 \\
\hline $\mathrm{OH}$ & $\begin{array}{l}\text { substrate }(10.5 \mathrm{~cm}) \\
\text { Bioswales/vegetated }\end{array}$ & Native prairie & $2-3 \mathrm{yr}$ & 31.00 & Whittinghill et al. 2014 \\
\hline NC & $\begin{array}{l}\text { swales } \\
\text { Bioswales/vegetated }\end{array}$ & Roadside vegetated filter strips & $37 \mathrm{yr}$ average & 1.90 & Bouchard et al. 2013 \\
\hline NC & $\begin{array}{l}\text { swales } \\
\text { Bioswales/vegetated }\end{array}$ & Roadside vegetated filter strips & $21.5 \mathrm{yr}$ average & 3.60 & Bouchard et al. 2013 \\
\hline Review & swales & & Average over 30 yr period & 6.20 & $\begin{array}{l}\text { Kavehei et al. } 2018 \\
\text { Flynn and Traver 2013; }\end{array}$ \\
\hline Review & Rain garden & & $\begin{array}{l}\text { Average over } 30 \text { yr period } \\
3 \text { yr initial establishment }\end{array}$ & 20.97 & Kavehei et al. 2018 \\
\hline Midwest & Native grassland & & and $5 \mathrm{yr}$ mature system & $1.24-4.94$ & Patchett and Weaner 2015 \\
\hline
\end{tabular}




\section{Tradeoffs between converting U-M landholdings from agriculture to sustainable agriculture, solar panels, wetlands, or forests.}

The following are considerations specifically for Harper Preserve, a 375-acre SEAS property in Argentine Township, 43 miles north of Ann Arbor. The property contains Murray Lake (a 40-acre lake), 80 acres of conventional cropland, oak-hickory forest, marshland, and old fields in transition to forest. The farm is currently under a private lease for farming in a corn/soy rotation by Wolverton Farms. This property is not open to the public but could potentially be used for teaching and research (DeYoung et al. 2020).

To prioritize biosequestration potentials, our recommendation was to transition the agricultural areas to wetlands with caveats regarding SEAS management preferences and potential lease arrangements (see Recommendation 1c). In "Creating a Vision for SEAS Properties," a group masters project undertaken by U-M SEAS graduate students (including graduate students on the Biosequestration IAT) hereafter referred to as DeYoung et al. (2020), the SEAS masters team imagined multiple potential land-use plans at Harper Preserve. Proposed options included an educational sustainable agriculture demonstration and research site with potential for a solar energy farm.

We would like to highlight that here we are only considering conversion of the current agricultural lands at Harper Preserve, while DeYoung et al. (2020) included additional "herbaceous" lands as part of the solar panel conversion area. We note the herbaceous land cover areas at Harper are not contiguous (many represent canopy openings) and the identity of broader swaths of herbaceous cover should be investigated carefully, as they may represent remnant prairie or savanna, which should be protected.

Below, we provide options in general order of biosequestration potential for land-use conversions for the current agricultural field area and mention potential tradeoff considerations.

\section{Wetlands}

Conversion of agricultural fields to wetlands would provide the largest biosequestration increase. See Recommendation 1c in our Final Report and our discussion of prioritization of wetland ecosystems in regard to biosequestration throughout. Depending on Harper Preserve topography, however, this may not be suitable for all areas of former agricultural fields. That said, breakup of drainage tiles may make this feasible if used at the site.

\section{Deciduous forest}

The historic land cover at Harper Preserve in the current farmed area would have been Oak-Hickory Forest in 1800 (LANDFIRE). A restoration to deciduous forest would be the most similar habitat restoration to historic habitat. Trees, however, are expensive $(\$ 800$ per tree was provided as a cost for planting on campus by Ann Arbor Facilities and Operations) and would require fertilizing and watering until established.

\section{$\underline{\text { Prairie }}$}

This would be the least-expensive option to transition to a "native" habitat. The state of Indiana USDA NRCS has compared former agricultural fields that have been converted to grasslands and found an increase in carbon sequestered compared to agricultural fields that continued to increase over a 20 -year period. The first 10 years of carbon 
sequestered in soil ranged from 1.0 to $1.8 \mathrm{tCO}_{2} \mathrm{e} / \mathrm{h} / \mathrm{yr}$, and 0.6 to $1.51 .8 \mathrm{tCO}_{2} \mathrm{e} / \mathrm{h} / \mathrm{yr}$ in the next 10 years (Smith et al. 2002).

\section{Renewable energy considerations with prairie vegetation}

Well-established management techniques to achieve desirable plant communities would have to be altered to include green energy production (e.g., burning or mowing tend to be implemented on a near annual time frame early on in restoration projects). It appears more typical to incorporate wind turbines as a renewable energy source in (nonremnant) prairie, as turbine height is much greater than prairie plant height (many species fall within $6{ }^{\prime}-12^{\prime}$ range at full height).

\section{Agrivoltaic options}

Agrivoltaics (APV) are an interesting and exciting area of research. We provide below a few considerations and tradeoffs to consider if this option is pursued. First, we would like to highlight work in this area completed by DeYoung et al. (2020):

There are over 80 acres of agricultural fields and 33 acres of herbaceous cover at Harper Preserve that can be converted into a renewable energy demonstration area. ... Such solar farms can produce electricity at about $150 \mathrm{~kW} / \mathrm{acre}$ (https://newlook.dteenergy.com), though agrivoltaic systems are constructed at a slightly lower density of solar panels than a traditional solar farm. ... If all available agricultural and herbaceous land was converted to solar, the property could potentially produce $16.95 \mathrm{MW} /$ year which would be the second largest solar farm in Michigan. At 18\% efficiency this would produce $\$ 2.7$ million dollars worth of electricity (assuming $\$ 0.10 / \mathrm{kWh}$ ) per year.

We caution that the electricity production potential calculated above by DeYoung et al. (2020) includes an overestimation of potential area and an overestimation of photovoltaics density. Specifically, the calculations above include 33 acres of herbaceous land cover not in agricultural production, much of which is not contiguous and represents opening pockets within forested stands or the shoreline of Lake Murray. Additionally, though proposed by DeYoung et al. (2020) as a limiting factor, the calculations do not account for agrivoltaic systems being constructed at lower densities than traditional solar farms. Though DeYoung et al. (2020) mention potentials for solar panels above agriculture can be beneficial or not impact crop yields, we feel it necessary to mention the study cited was performed in arid regions where shade and retention of soil moisture may be more important for crop success than in the Midwest. Recent work out of similar climates in Europe illustrate that APV is recommended in combination with permanent cultures (e.g., berries, fruits, wine grapes; Schindele et al. 2020), which could be considered as part of a sustainable agriculture program, allowing SEAS to expand potential teaching and research and experiential learning opportunities.

\section{Sustainable agriculture (solar field potential)}

Changes toward more sustainable farming practices (e.g., "conservation tillage" as no-till or reduced till) can increase soil carbon storage via more stable soils less prone to erosion. If $\mathrm{U}-\mathrm{M}$ were to take over the farming practice or begin an incentive system with the leasing farmer to prioritize reduction of a carbon footprint, many things could be considered as a step toward sustainability. Not knowing or having control of the farming 
choices, it is difficult to know what to prioritize. However, permacultures, installation of conservation buffers (e.g., grassed waterways, native field margins), and localization of the supply and sales chains can all help.

An excerpt from DeYoung et al. (2020):

"The potential for sustainable agriculture at Harper is extremely auspicious. In our interview with Mr. Wolverton, he stated that the university was doing a fine job with the property currently, and recommended being in touch with Dennis and Sean Corey, who would be a wealth of information. This undertaking could benefit from reclaiming the 70 or so acres that have currently entered early succession, and though this land has not been farmed in over forty years, Mr. Wolverton expressed an interest in seeing it planted again. Thus, we see the promising beginnings of a dual-use partnership for the property: research in sustainable energy and agriculture, in conjunction with overlaps with the local farming community to help manage the property's potential. As there are very few avenues into the community other than local farming networks, this approach would be an encouraging model for students to take part in, leading to powerful insights into generational farming."

\section{Fescue or turf with solar}

Fescue or turf beneath solar panels would be the easiest vegetation to maintain, especially if no-mow grasses were used (which would also reduce emissions). It may involve a few years of seeding to establish and some watering support. Invasive plants or woody plant encroachment could be prevented chemically. Fescue or turf has low biosequestration potential.

\section{$\underline{\text { Traditional agriculture (can not support solar field) }}$}

Currently the fields at Harper Preserve are traditionally farmed using a corn/soy rotation. Calculating the carbon footprint of agricultural production fields represents a tangled web of calculations including, but not limited to: location, parcel size, surface soil texture, approximate historic land-use changes, tillage and fertilization practices, future land management and carbon storage practices, and current fossil fuel electricity consumption (USDA NRCS). While the location and size are set, the remaining inputs are controlled by the farmer, not U-M, and we are unable to determine potential sequestration-or more probable-emissions, resulting from the farmed area at Harper Preserve.

That said, overall, agricultural soils can contain substantial carbon in the midwestern US (typically 20 to 80 tonnes per hectare in the top $20 \mathrm{~cm}$ ) they are depleted in carbon relative to native ecosystems (typically $30 \%-50 \%$ loss; Smith 2002). 


\section{Appendix L - Glossary of terms}

accuracy assessments

aerial imagery

AmeriFlux

biosequestration

biosequestration rate

bioswales

carbon cycle

research

carbon flux

carbon storage

carbon towers

cultural services

decomposition rate

economic valuation
The procedure used to quantify the reliability of a classified image. The standard accuracy assessment procedure is to construct an "error matrix," which compares the classified image to another data source that is considered to be accurate or ground truth data.

Photographs taken from an aircraft or other flying object, such as aircraft, helicopters, drones, or balloons.

AmeriFlux is a network of PI-managed sites measuring ecosystem $\mathrm{CO}_{2}$, water, and energy fluxes in North, Central and South America. ${ }^{1}$

The natural process of capturing and storing carbon dioxide from the atmosphere through plants and other biological organisms.

The rate at which carbon dioxide is captured and stored through biological processes.

Vegetated channels usually by road side designed to concentrate and convey stormwater runoff while removing debris and pollution.

Research focusing on the exchange and transformation of carbon within and between Earth's oceans, land, atmosphere, and biosphere. ${ }^{2}$

The amount of carbon exchanged between carbon pools.

The placement of $\mathrm{CO}_{2}$ into a repository where it is likely to remain stored permanently. In this report, carbon storage refers to the storage of carbon in vegetation and soil.

A device used to record the flux of carbon dioxide, especially common in forests to record sequestration and respiration of carbon dioxide.

The non-material benefits people obtain from ecosystems, such as cultural identity, aesthetics, and spiritual experience related to the natural environment. ${ }^{3}$

The rate of which organic substances are broken down.

A measure to provide an empirical account of the value of services provided by the environment. 
ecosystem services

extensive green roofs

field-based vegetation surveys

free surface area wetland

gene pool protection

genetic resources

GIS

green infrastructure

green spaces

land ethic prioritization

Land use and land cover (LULC)

LULC classification maps
The direct and indirect contributions of ecosystems to human well-being. These can include supporting, regulating, provisioning, and cultural/relational services.

Roofs with vegetation that need little maintenance and no permanent irrigation system.

Collection of vegetation data in the field such as measurement of size, density and diameter at breast height of trees as needed, detailed description for this study in Appendix $\mathrm{C}$ method 5.

Wetland systems where the water surface is exposed to the atmosphere.

Maintaining the genetic diversity, which is associated with more robust populations and can survive more intense selection.

Genetic material that can have actual or potential value.

A geographic information system (GIS) is a system designed to capture, store, manipulate, analyze, manage, and present spatial or geographic data.

An approach to wet weather management that uses natural systems-or engineered systems that mimic natural processes-to enhance overall environmental quality and provide utility services. As a general principle, green infrastructure techniques use soils and vegetation to infiltrate, evapotranspire, and/or recycle stormwater runoff.

An area of vegetation, such as grass or trees, set apart in an urban environment.

A philosophical or theoretical framework about how humans should regard the land. In this report, we refer to land ethic by Aldo Leopold focusing on the preservation of healthy ecosystems rather than strictly human centered views of the environment.

The categorization or classification of human activities and natural elements on the landscape within a specific time frame based on established scientific and statistical methods of analysis of appropriate source materials.

Maps created by converting image pixels or image regions to classes that represent self-similar earth surface features. 
native gardens

natural lands

productivity

rain gardens

regenerative agriculture

remote sensing

resilience

resistance

social cost of carbon

soil cores

stability
The use of native plants that are indigenous to the geographic area for creating gardens, both to minimize additional input of fertilizer and water, and to maximize ecosystem functions.

In this report, natural lands refers to properties where the primary landuse of the property is forest, wetland, or herbaceous grassland cover. This includes the SEAS properties, MBGNA, UMBS, Camps, and Reserves and Preserves.

The fertility or capacity of an area, or the production of new biomass.

A rain garden is a strategically located low area planted with native vegetation that intercepts runoff. Other terms include mini-wetland, storm water garden, water quality garden, stormwater marsh, backyard wetland, low swale, wetland biofilter, or bioretention pond. Rain gardens are designed to direct polluted runoff into a low, vegetated area, where the pollutants can be captured and filtered.

Farming and grazing practices that, among other benefits, rebuild soil organic matter and restore degraded soil biodiversity—resulting in both carbon drawdown and improvement of the water cycle. ${ }^{4}$

Obtaining information about an object, area, or phenomenon through the analysis of data acquired by a device that is not in contact with the object, area, or phenomenon under investigation. In this report, remote sensing more narrowly refers to the monitoring of land through aerial and satellite imagery.

The ability of an ecosystem to withstand disturbances without moving away from its current stable state.

The biotic and abiotic factors in a recipient ecosystem that limit the population growth of an invading species. ${ }^{5}$

A measure of the economic harm from those impacts, expressed as the dollar value of the total damages from emitting one ton of carbon dioxide into the atmosphere. ${ }^{6}$

A cylindrical sample of soil, which could be used to test carbon density.

An equilibrium state that an ecosystem could return to after a perturbation. 
sustainable agriculture

tribal leadership People taking leadership roles in indigenous tribes.

turfgrass

urban heat island

urban meadows

Any grasses that are grown to form turf. areas due to human activities.
Farming practices that can be conducted indefinitely to meet needs while not compromising the environment.

An urban area that is significantly warmer than the surrounding rural

Intentional green spaces in urban areas that aim to promote natural regeneration, leading to increased biodiversity, improved water quality, and a reduction in stormwater runoff and soil erosion.

1. "About the AmeriFlux Network." n.d. Accessed April 27, 2020. https://ameriflux.Ibl.gov/about/about-ameriflux/.

2. "Cultural Services | Ecosystem Services \& Biodiversity (ESB) | Food and Agriculture Organization of the United Nations." n.d. Accessed April 27, 2020. http://www.fao.org/ecosystem-services-biodiversity/background/cultural-services/en/.

3. Tzortziou, Maria, Marcy Litvak, and Gyami Shrestha. 2017. "Coordinating and Communicating Carbon Cycle Research." Eos, September. https://doi.org/10.1029/2017eo080201.

4. "Why Regenerative Agriculture" | Regeneration International. 2019. Accessed April 27, 2020. https://regenerationinternational.org/why-regenerative-agriculture/.

5. D'Antonio, Carla M., and Meredith Thomsen. 2004. "Ecological Resistance in Theory and Practice." Weed Technology 18 (sp1): 1572-1577. https://doi.org/10.1614/0890037X(2004)018[1572:ERITAP]2.0.CO;2.

6. "The True Cost of Carbon Pollution | Environmental Defense Fund." n.d. Accessed April 27, 2020. https://www.edf.org/true-cost-carbon-pollution. 


\section{Appendix M - Team biographies}

\section{Faculty co-leads}

Heather A. Dawson is an Associate Professor in the Biology Department at UM-Flint. Her wildlife ecology research primarily focuses on ways to improve the management of invasive species. She studies population dynamics of invasive species as well as the ecology and connectivity of aquatic systems.

Rebecca K. Tonietto is an Assistant Professor in the Biology Department at UM-Flint. An ecologist with degrees in Plant Biology and Conservation, she studies wild bees and plant communities in restored and urban systems with a focus on restoration planning, community engaged research, and conservation.

\section{Student team}

Nicole Blankertz is an undergraduate student at UM-Flint studying Wildlife Biology and Writing. She plans to attend graduate school in the future, with interests in wildlife conservation ecology and behavior.

Hannah G. Mosiniak is a master's student at the School for Environment and Sustainability (SEAS) studying Geospatial Data Science. Her research explores the relationship between urban heat island effect and social vulnerability in the Great Lakes region.

Lara K. O'Brien is a master's student at U-M's School for Environment and Sustainability (SEAS). Focusing on Conservation Ecology and Environmental Informatics, her studies aim to utilize GIS and remote sensing to enhance conservation efforts and natural resource management.

Caleb Short is finishing up his degree in Wildlife Biology at $U$ of M-Flint. In the future, he hopes to take his love for learning and his passion for wildlife into the field to work in conservation.

Chenyang Su is a master's student at U-M's School for Environment and Sustainability (SEAS) focusing on Conservation Ecology. She is interested in biodiversity and ecosystem ecology, hoping to make impacts by involving in small scale conservation projects.

Cyrus Van Haitsma is a master's student at U-M's School for Environment and Sustainability (SEAS). He is focusing on Conservation Ecology and hopes to eventually use what he's learned in his studies to work in conservation and natural resource management. 


\section{References}

Badiou, P., R. McDougal, D. Pennock, and B. Clark. 2011. "Greenhouse gas emissions and carbon sequestration potential in restored wetlands of the Canadian prairie pothole region." Wetlands Ecology and Management 19(3): 237-256. http://dx.doi.org/10.1007/s11273011-9214-6.

Baldocchi, D., E. Falge, L. Gu, R, Olson, D. Hollinger, S. Running, P. Anthoni, C. Bernhofer, K. Davis, R. Evans, J. Fuentes, A. Goldstein, G. Katul, B. Law, X. Lee, Y. Malhi, T. Myers, W. Munger, W. Oechel, K. T. Paw, K. Pilegaard, H. P. Schmid, R. Valentini, S. Verma, T. Vesala, K. Wilson, and S. Wofsy. 2001. "FLUXNET: A new tool to study the temporal and spatial variability of ecosystem-sale carbon dioxide, water vapor, and energy flux densities." Bulletin of the American Meteorological Society 82(11): 2415-2434. https://doi.org/10.1175/1520-0477(2001)082<2415:FANTTS>2.3.CO;2.

Barron-Gafford, G., M. Pavao-Zuckerman, R. Minor, L. Sutter, I. Barnett-Moreno, D. Blackett, M. Thompson, K. Dimond, A. Gerlak, G. Nabhan, and J. Macknick. 2019. "Agrivoltaics provide mutual benefits across the food-energy-water nexus in drylands." Nature Sustainability 2(9): 848-855.

Bernal, B., and W. J. Mitsch. 2012. "Comparing carbon sequestration in temperate freshwater wetland communities." Global Change Biology 18(5): 1636-1647. https://doi.org/10.1111/j.1365-2486.2011.02619.x. $<$ Go to ISI>://WOS:000302543500015.

Bouchard, N. R., D. L. Osmond, R. J. Winston, and W. F. Hunt. 2013. "The capacity of roadside vegetated filter strips and swales to sequester carbon." Ecological Engineering 54:227232. https://doi.org/10.1016/j.ecoleng.2013.01.018.

Brix, H., B. K. Sorrell, and B. Lorenzen. 2001. "Are Phragmites-dominated wetlands a net source or net sink of greenhouse gases?" Aquatic Botany 69(2-4): 313-324. https://doi.org/10.1016/s0304-3770(01)00145-0. <Go to ISI>://WOS:000168254100015.

California Environmental Protection Agency. 2017. California's 2017 climate change scoping plan. Air Resources Board.

Carmichael, C., C. Danks, and C. Vatovec. 2019. "Green infrastructure solutions to health impacts of climate change: Perspectives of affected residents in Detroit, Michigan, USA." Sustainability 11(20): 15. https://doi.org/10.3390/su11205688. <Go to ISI>://WOS:000498398900145.

CNT. 2009. "National stormwater calculator." Accessed April 27, 2020. https://greenvalues.cnt.org/national/benefits detail.php.

Congressional Research Service. 2018. Greenhouse gas emissions and sinks in U.S. agriculture. https://fas.org/sgp/crs/misc/IF10979.pdf.

Costanza, R., R. de Groot, and S. Farberk. 1997. "The value of the world's ecosystem services and natural capital." Nature 387(15): 253-260. https://doi.org/10.1016/S09218009(98)00020-2.

Costanza, R., R. de Groot, P. Sutton, S. van der Ploeg, S. J. Anderson, I. Kubiszewski, S. Farber, and R. K. Turner. 2014. "Changes in the global value of ecosystem services." Global Environmental Change-Human and Policy Dimensions 26:152-158. 
https://doi.org/10.1016/i.gloenvcha.2014.04.002. < Go to

ISI>://WOS:000337858600015.

Curtis, P. S., P. J. Hanson, P. Bolstad, C. Barford, J. C. Randolph, H. P. Schmid, and K. B. Wilson. 2002. "Biometric and eddy-covariance based estimates of annual carbon storage in five eastern North American deciduous forests." Agricultural and Forest Meteorology 113(14): 3-19. https://doi.org/10.1016/s0168-1923(02)00099-0. <Go to |SI>://WOS:000179188300002.

Daily, G. C., S. Polasky, J. Goldstein, P. M. Kareiva, H. A. Mooney, L. Pejchar, T. H. Ricketts, J. Salzman, and R. Shallenberger. "Ecosystem services in decision making: time to deliver." Frontiers in Ecology and the Environment 7(1): 21-28. https://doi.org/10.1890/080025

Dass, P., B. Z. Houlton, Y. P. Wang, and D. Warlind. 2018. “Grasslands may be more reliable carbon sinks than forests in California." Environmental Research Letters 13(7): 8. https://doi.org/10.1088/1748-9326/aacb39. <Go to ISI>://WOS:000438210100001.

de Groot, R., M. A. Wilson, and R. M. .J. Boumans. 2002. "A typology for the classification, description and valuation of ecosystem functions, goods and services." Ecological Ecnomics 41(3): 393-408. https://doi.org/10.1016/S0921-8009(02)00089-7.

de Groot, R., R. Alkemade, L. Braat, L. Hein, and L. Willemen. 2010. “Challenges in integrating the concept of ecosystem services and values in landscape planning, management and decision making." Ecological Complexity 7(3): 260-272. https://doi.org/10.1016/j.ecocom.2009.10.006. <Go to ISI>://WOS:000281275200002.

de Groot, R., L. Brander, S. van der Ploeg, R. Costanza, F. Bernard, L. Braat, M. Christie, N. Crossman, A. Ghermandi, L. Hein, S. Hussain, P. Kumar, A. McVittie, R. Portela, L. C. Rodriguez, P. ten Brink, and P. van Beukeringh. 2012. "Global estimates of the value of ecosystems and their services in monetary units." Ecosystem Services 1(1): 50-61. https://doi.org/10.1016/j.ecoser.2012.07.005. <Go to ISI>://WOS:000209520400007.

de Klein, J. J. M., and A. K. van der Werf. 2014. "Balancing carbon sequestration and GHG emissions in a constructed wetland." Ecological Engineering 66:36-42. https://doi.org/10.1016/j.ecoleng.2013.04.060. <Go to ISI>://WOS:000336445800005.

Dernoeden, P. H., C. A. Bigelow, J. E. Kaminski, and J. M. Krouse. 2003. "Smooth crabgrass control in perennial ryegrass and creeping bentgrass tolerance to quinclorac." Hortscience 38(4): 607-612. https://doi.org/10.21273/hortsci.38.4.607. <Go to ISI>://WOS:000184487100026.

DeYoung, M., Z. Ding, Z. Li, L. O’Brien, P. Siciliano, and C. Van Haitsma. 2020. “Creating a vision for SEAS properties." Master's thesis, University of Michigan. http://hdl.handle.net/2027.42/154880.

Environmental Protection Agency. 1994. A handbook of constructed wetlands: A guide to creating wetlands for agricultural wastewater, domestic wastewater, coal mine drainage, stormwater in the Mid-Atlantic Region. Washington, DC: Office of Water. 
Environmental Protection Agency. 2000. Constructed wetlands treatment of municipal wastewaters. Washington, DC: Office of Research and Development Manual EPA/625/R99/010.

Environmental Protection Agency. 2014. Reducing urban heat islands: Compedium of strategies. Green roofs. Washington, DC: Office of Atmospheric Programs.

https://www.epa.gov/sites/production/files/2014-

06/documents/greenroofscompendium.pdf.

ESRI. 2020. ArcMap 10.8. Redlands, CA: ESRI.

Euskirchen, E. S., J. Chen, H. Li, E. J. Gustafson, and T. R. Crow. 2002. “Modeling landscape net ecosystem productivity (LandNEP) under alternative management regimes." Ecological Modelling 154(1-2): 75-91. https://doi.org/10.1016/S0304-3800(02)00052-2.

Flynn, K. M., and R. G. Traver. 2013. "Green infrastructure life cycle assessment: A bioinfiltration case study." Ecological Engineering 55:9-22. https://doi.org/10.1016/j.ecoleng.2013.01.004.

Froelich, N., H. Croft, J. M. Chen, A. Gonsamo, and R. M. Staebler. 2015. "Trends of carbon fluxes and climate over a mixed temperate-boreal transition forest in southern Ontario, Canada." Agricultural and Forest Meterology 211-212:72-84.

https://doi.org/10.1016/i.agrformet.2015.05.009.

Gahagan, A., C. P. Giardina, J. S. King, D. Binkley, K. S. Pregitzer, and A. J. Burton. 2015. “Carbon fluxes, storage and harvest removals through 60 years of stand development in red pine plantations and mixed hardwood stands in Northern Michigan, USA." Forest Ecology and Management 337:88-97. https://doi.org/10.1016/..foreco.2014.10.037.

Getter, K. L., D. B. Rowe, G. P. Robertson, B. M. Cregg, and J. A. Andresen. 2009. "Carbon sequestration potential of extensive green roofs." Environmental Science \& Technology 43(19): 7564-7570. https://doi.org/10.1021/es901539x. <Go to ISI>://WOS:000270136500065.

Gren, I.-M., and A. A. Zeleke. 2016. "Policy design for forest carbon sequestration: A review of the literature." Forest Policy and Economics 70:128-136. https://doi.org/10.1016/j.forpol.2016.06.008. <Go to ISI>://WOS:000381534100016.

Hooper, D. U., F. S. Chapin, J. J. Ewel, A. Hector, P. Inchausti, S. Lavorel, J. H. Lawton, D. M. Lodge, M. Loreau, S. Naeem, B. Schmid, H. Setala, A. J. Symstad, J. Vandermeer, and D. A. Wardle. 2005. "Effects of biodiversity on ecosystem functioning: A consensus of current knowledge." Ecological Monographs 75(1): 3-35. https://doi.org/10.1890/040922. < Go to ISI>://WOS:000227254000001.

Huh, K. Y., M. Deurer, S. Sivakumaran, K. McAuliffe, and N. S. Bolan. 2008. “Carbon sequestration in urban landscapes: the example of a turfgrass system in New Zealand." Australian Journal of Soil Research 46(7): 610-616. https://doi.org/10.1071/SR07212. Intergovernmental Panel on Climate Change (IPCC). 2014. Climate change 2014: A synthesis report. Contribution of working Groups I, II and III to the Fifth Assessment Report of the Intergovernmental Panel on Climate Change. Geneva, Switzerland.

Jana, B. K., S. Biswas, M. Majumder, P. K. Roy, and A. Mazumdar. 2009. "Carbon sequestration rate and aboveground biomass carbon potential of four young species." Journal of Ecology and Natural Environment 1(2): 15-24. 
Jenkins, J. C., D. C. Chojnacky, L. S. Heath, and R. A. Birdsey. 2003. "National-scale biomass estimators for Unites States tree species." Forest Science 49(1): 12-35.

Kalejs, J. 2018. UMBS Research Spotlight: FoRTE explores forest resilience and carbon storage. https://Isa.umich.edu/umbs/news-events/all-news/search-news/umbs-researchspotlight--forte-explores-how-carbon-storing-fores.html.

Kavehei, E., G. A. Jenkins, M. F. Adame, and C. Lemckert. 2018. "Carbon sequestration potential for mitigating the carbon footprint of green stormwater infrastructure." Renewable \& Sustainable Energy Reviews 94:1179-1191. https://doi.org/10.1016/i.rser.2018.07.002. $<$ Go to $|S|>$ ://WOS:000446310000084.

King, D. M., and C. C. Bohlen. 1994. A technical summary of wetland restoration costs in the continental United States. University of Maryland CEES Tech. Rep. UMCEES-CBL-94-048. https://nepis.epa.gov/Exe/ZyPDF.cgi/40000KWS.PDF?Dockey=40000KWS.PDF.

LANDFIRE. Accessed March 2020. https://www.landfire.gov/index.php.

Lee, X., J. D. Fuentes, R. M. Staebler, and H. H. Neumann. "Long-term observation of the atmospheric exchange of $\mathrm{CO} 2$ with a temperate deciduous forest in southern Ontario, Canada." Journal of Geophysical Research: Atmospheres 104(D13): 15975-15984. https://doi.org/10.1029/1999JD900227

Law, B. E., E. Falge, L. Gu, D. D. Baldocchi, P. Bakwin, P. Berbigier, K. Davis, A. J. Dolman, M. Falk, J. D. Fuentes, A. Goldstein, A. Granier, A. Grelle, D. Hollinger, I. A. Janssens, P. Jarvis, N. O. Jensen, G. Katul, Y. Mahli, G. Matteucci, T. Meyers, R. Monson, W. Munger, W. Oechel, R. Olson, K. Pilegaard, K. T. Paw U, H. Thorgeirsson, R. Valentini, S. Verma, T. Vesala, K. Wilson, and S. Wofsy. 2002. "Environmental controls over carbon dioxide and water vapor exchange of terrestrial vegetation." Agricultural and Forest Meteorology 113(1-4): 97-120. https://doi.org/10.1016/S0168-1923(02)00104-1.

Millennium Ecosystem Assessment (MEA). 2005. Ecosystems and human well-being. Washington, D.C: Island Press. http://www.bioquest.org/wpcontent/blogs.dir/files/2009/06/ecosystems-and-health.pdf.

Ma, W., G. M. Domke, C. W. Woodall, and A. W. D'Amato. 2020. "Contemporary forest carbon dynamics in the northern US associated with land cover changes." Ecological Indicators 110. https://doi.org/10.1016/j.ecolind.2019.105901. <Go to ISI>://WOS:000507381800064.

Meerow, S., and J. P. Newell. 2017. "Spatial planning for multifunctional green infrastructure: Growing resilience in Detroit." Landscape and Urban Planning 159:62-75. https://doi.org/10.1016/j.landurbplan.2016.10.005. <Go to ISI>://WOS:000392687200008.

Miranda, M. L., D. A. Hastings, J. E. Aldy, and W. H. Schlesinger. 2011. "The environmental justice dimensions of climate change." Environmental Justice 4(1): 17-25.

Mitsch, W. J., B. Bernal, A. M. Nahlik, U. Mander, L. Zhang, C. J. Anderson, S. E. Jorgensen, and H. Brix. 2013. "Wetlands, carbon, and climate change." Landscape Ecology 28(4): 583- 
597. https://doi.org/10.1007/s10980-012-9758-8. < Go to

ISI>://WOS:000317845400002.

Mitsch, W. J., L. Zhang, K. C. Stefanik, A. M. Nahlik, C. J. Anderson, B. Bernal, M. Hernandez, and K. Song. 2012. "Creating wetlands: Primary succession, water quality changes, and selfdesign over 15 years." BioScience 62(3): 237-250.

https://doi.org/10.1525/bio.2012.62.3.5.

Nabuurs, G. J., O. Masera, K. Andrasko, P. Benitez-Ponce, R. Boer, M. Dutschke, E. Elsiddig, J. Ford-Robertson, P. Frumhoff, T. Karjalainen, O. Krankina, W. A. Kurz, M. Matsumoto, W. Oyhantcabal, N. H. Ravindranath, M. J. Sanz Sánchez, and X. Zhang. 2007. "Forestry. In Climate Change Mitigation." In Contribution of Working Group III to the Fourth Assessment Report of the Intergovernmental Panel on Climate Change, edited by B. Metz, O. R. Davidson, P. R. Bosch, R. Dave, and L. A. Meyer. Cambridge, UK: Cambridge University Press.

Nahlik, A. M., and M. S. Fennessy. 2016. "Carbon storage in US wetlands." Nature Communications 7. https://doi.org/10.1038/ncomms13835. <Go to ISI>://WOS:000389671100001.

$\mathrm{Niu}, \mathrm{X}$. Z., and S. W. Duiker. 2006. "Carbon sequestration potential by afforestation of marginal agricultural land in the midwestern US." Forest Ecology and Management 223(1-3): 415-427. https://doi.org/10.1016/i.foreco.2005.12.044. <Go to ISI>://WOS:000235780300043.

Odefey, J., S. Detwiler, K. Rousseau, A. Trice, R. Blackwell, K. O'Hara, M. Buckley, T. Souhlas, S. Brown, and P. Raviprakash. 2012. Banking on green: A look at how green infrastructure can save municipalities money and provide economic benefits community-wide. American Rivers, American Society of Landscape Architects, ECONorthwest, Water Environment Federation, Portland, Oregon.

Ott, J. P., B. B. Hanberry, M. Kahlil, M. W. Paschke, M. P. van der Burg, and A. J. Prenni. In press. "Energy development and production in the Great Plains: Implications and mitigation opportunities." Rangeland Ecology and Management. https://doi.org/10.1016/j.rama.2020.05.003.

Pan, Y. D., R. A. Birdsey, J. Y. Fang, R. Houghton, P. E. Kauppi, W. A. Kurz, O. L. Phillips, A. Shvidenko, S. L. Lewis, J. G. Canadell, P. Ciais, R. B. Jackson, S. W. Pacala, A. D. McGuire, S. L. Piao, A. Rautiainen, S. Sitch, and D. Hayes. 2011. "A large and persistent carbon sink in the world's forests." Science 333(6045): 988-993. https://doi.org/10.1126/science.1201609. <Go to ISI>://WOS:000294000400048.

Patchett, J., and L. Weaner. 2015. "Native meadows and grasslands: From vision to reality." https://learn.asla.org/asla/sessions/119/view.

Perrow, M. R., and A. J. Davy, eds. 2002. Handbook of ecological restoration: Restoration in practice. Vol. 2. New York: Cambridge University Press.

Popkin, G. 2019. “The forest question." Nature 565(7739): 280-282. https://doi.org/10.1038/d41586-019-00122-z. <Go to ISI>://WOS:000455781600015.

Pregitzer, K. S., and E. S. Euskirchen. 2004. "Carbon cycling and storage in world forests: Biome patterns related to forest age." Global Change Biology 10(12): 20522077. https://doi.org/10.1111/j.1365-2486.2004.00866.x. 
Qian, Y. L., and R. F. Follett. 2002. "Assessing soil carbon sequestration in turfgrass systems using long-term soil testing data." Agronomy Journal 94(4): 930-935. https://doi.org/10.2134/agronj2002.9300. <Go to ISI>://WOS:000177015800028.

Qian, Y. L., R. F. Follett, and J. M. Kimble. 2010. "Soil organic carbon input from urban turfgrasses." Soil Science Society of America Journal 74(2): 366-371. https://doi.org/10.2136/sssaj2009.0075. <Go to ISI>://WOS:000275187300004.

R Core Team. R: A Language and Environment for Statistical Computing 3.6.1. Vienna, Austria. https://cran.r-project.org/doc/manuals/fullrefman.pdf.

Rosli, F. A., K. E. Lee, T. G. Choo, M. Mokhtar, M. T. Latif, T .L. Goh, and N. Simon. 2017. "The use of constructed wetlands in sequestrating carbon: An overview." Nature Environment and Pollution Technology 16(3): 813-819. http://www.neptjournal.com/uploadimages/NL-61-19-(17)D-606.pdf.

Reddy, G. B., C. W. Raczowski, J. S. Cyrus, and A. Szogi. 2016. "Carbon sequestration in a surface flow constructed wetland after 12 years of swine wastewater treatment." Water Science \& Technology 73(10): 2501-2508. https://doi.org/10.2166/wst.2016.112

Saigusa, N., S. Yamamoto, S. Murayama, H. Kondo, and N. Nishimura. 2002. "Gross primary production and net ecosystem exchange of a cool-temperate deciduous forest estaimated by the eddy covariance method." Agricultural and Forest Meteorology 112(3 -4): 203-215. https://doi.org/10.1016/S0168-1923(02)00082-5

Schindele, S., M. Trommsdorff, A. Schlaak, T. Obergfell, B. Bopp, C. Reise, C. Braun, A. Weselek, A. Bauerle, P. Högy, A. Goetzberger, and E. Weber. 2020. "Implementation of agrophotovoltaics: Techno-economic analysis of the price-performance ratio and its policy implications." Applied Energy 265:114737. https://doi.org/10.1016/j.apenergy.2020.114737.

Schmid, H. P., C. S. B. Grimmond, F. Cropley, B. Offerle, and H.-B. Su. 2000. "Measurements of $\mathrm{CO}_{2}$ and energy fluxes over a mixed hardwood forest in the mid-western United States." Agricultural and Forest Meterology 103(4): 357-374. https://doi.org/10.1016/S01681923(00)00140-4.

Selhorst, A. L., and R. Lal. 2012. "Carbon sequestration in golf course turfgrass systems and recommendations for the enhancement of climate change mitigation potential." In Carbon sequestration in urban ecosystems, edited by R. Lal and B. Augustin. Dordrecht, Netherlands: Springer.

Smith, P., J. Brenner, K. Paustian, G. Bluhm, J. Cipra, M. Easter, E. T. Elliott, K. Killian, D. Lamm, J. Schuler, and S. Williams. 2002. Quantifying the change in greenhouse gas emissions due to natural resource conservation practice application in Indiana. Final report to the Indiana Conservation Partnership, Colorado State University Natural Resource Ecology Laboratory and USDA Natural Resources Conservation Service, Fort Collins, CO. https://www.nrcs.usda.gov/Internet/FSE DOCUMENTS/nrcs144p2 030361.pdf.

Tilman, D., F. Isbell, and J. M. Cowles. 2014. Biodiversity and ecosystem functioning. Annual Review of Ecology, Evolution, and Systematics 45:471-493. 
Tyndall, J., and T. Bowman. 2016. lowa nutrient reduction strategy best management practice cost overview series. Department of Ecology \& Natural Resource Management, lowa State University.

United Nations Framework Convention on Climate Change (UNFCCC). UN Climate Change Annual Report. 2018. Accessed April 2020. https://unfccc.int/sites/default/files/resource/UN-Climate-Change-Annual-Report2018.pdf.

US Department of Agriculture, US Department of the Interior. LANDFIRE, LANDFIRE: Land Cover Circa 1800.

US Fish and Wildlife Service. 2020. National Wetlands Inventory website. Accessed April 2020. http://www.fws.gov/wetlands/.

USDA-FSA-APFO Aerial Photography Field Office. 2015. “National Geospatial Data Asset (NGDA) NAIP Imagery." USDA-FSA-APFO Aerial Photography Field Office. http://gis.apfo.usda.gov/arcgis/rest/services/NAIP/NAIP Image Dates/MapServer.

USDA NRCS. 2019. Comet Farm: Whote Farm and Ranch carbon and greenhouse gas accounting system. USDA. June 2020. http://www.comet-farm.com.

Whittaker, R. H., F. H. Bormann, G. E. Likens, and T. G. Siccama. 1974. "The Hubbard Brook ecosystem study: Forest biomass and production." Ecological Monographs 44(2): 233252.

Whittinghill, L. J., D. B. Rowe, R. Schutzki, and B. M. Cregg. 2014. "Quantifying carbon sequestration of various green roof and ornamental landscape systems." Landscape and Urban Planning 123:41-48. https://doi.org/10.1016/i.landurbplan.2013.11.015.

Yamamoto, S., S. Murayama, N. Saigusa, and H. Kando. 1999. "Seasonal and inter-annual variation of $\mathrm{CO}_{2}$ flux between a temperate forest and the atmosphere in Japan." Tellus B: Chemical and Physical Meterology 51(2): 402-413. https://doi.org/10.3402/tellusb.v51i2.16314.

Zirkle, G., R. Lal, and B. Augustin. 2011. "Modeling carbon sequestration in home lawns." HortScience 46(5): 808-814. https://doi.org/10.21273/hortsci.46.5.808. <Go to ISI>://WOS:000291139500020.

Ziter, C. D., E. J. Pedersen, C. J. Kucharik, and M. G. Turner. 2019. "Scale-dependent interactions between tree canopy cover and impervious surfaces reduce daytime urban heat during summer." Proceedings of the National Academy of Sciences of the United States of America 116(15): 7575-7580. https://doi.org/10.1073/pnas.1817561116. <Go to ISI>://WOS:000463936900060. 